U.S. Department of the Interior

U.S. Geological Survey

\title{
Map and Database of Quaternary Faults and Folds in Colombia and its Offshore Regions
}

By

Gabriel Paris, Michael N. Machette, Richard L. Dart, and Kathleen M. Haller

\section{Open-File Report 00-0284}

This report is preliminary and has not been reviewed for conformity with U.S. Geological Survey editorial standards nor with the North American Stratigraphic Code. Any use of trade names in this publication is for descriptive purposes only and does not imply endorsement by the U.S. Geological Survey.

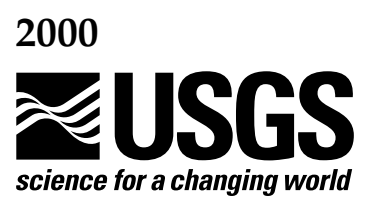




\title{
MAP AND DATABASE OF QUATERNARY FAULTS AND FOLDS IN COLOMBIA AND ITS OFFSHORE REGIONS
}

\section{A project of the International Lithosphere Program Task Group II-2, Major Active Faults of the World}

\author{
Data and map compiled by \\ ${ }^{1}$ GABRIEL PARIS, ${ }^{2}$ MICHAEL N. MACHETTE, ${ }^{2}$ RICHARD L. DART, \\ AND ${ }^{2}$ KATHLEEN M. HALLER \\ 1 Departamento de Geografia \\ Universidad del Valle \\ Melendez, Cali, Colombia \\ ${ }^{2}$ U.S. Geological Survey (USGS) \\ Central Geologic Hazards Team \\ MS 966, P.O. Box 25046 \\ Denver, Colorado, USA
}

Regional Coordinator for South America

CARLOS COSTA

Universidad Nacional de San Luis

Departmento de Geologia

Casilla de Correo 320

San Luis, Argentina

ILP Task Group II-2 Co-Chairman, Western Hemisphere

MICHAEL N. MACHETTE

U.S. Geological Survey (USGS)

Central Geologic Hazards Team

MS 966, P.O. Box 25046

Denver, Colorado, USA 


\section{TABLE OF CONTENTS}

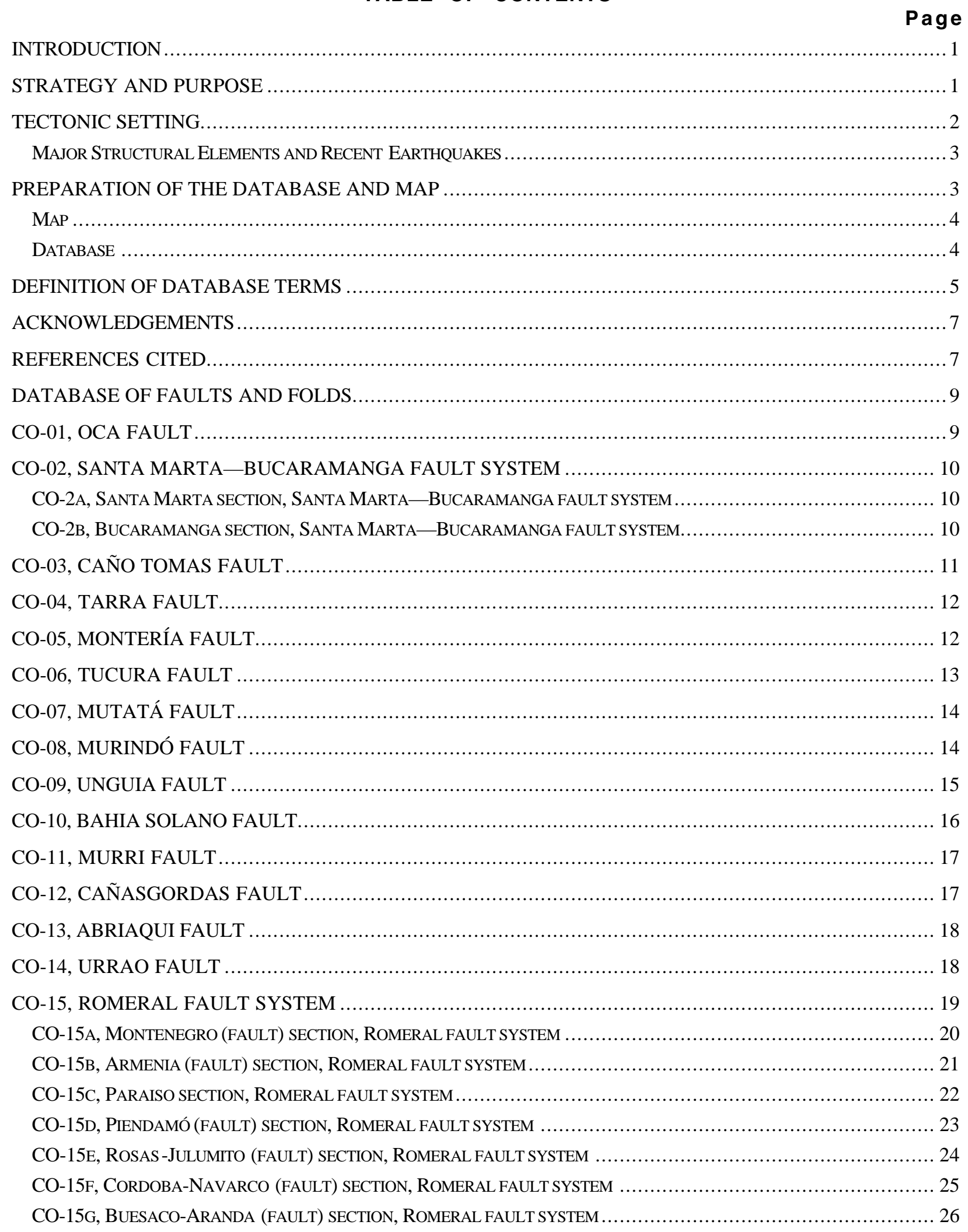




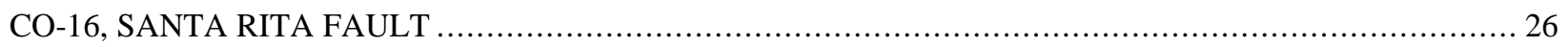

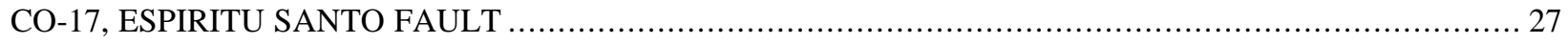

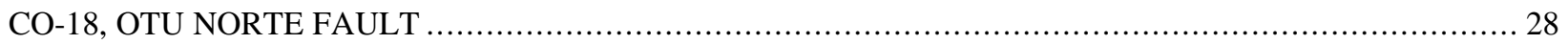

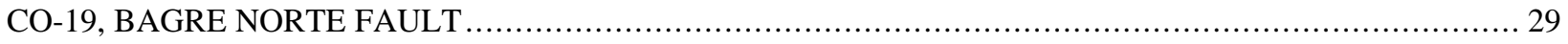

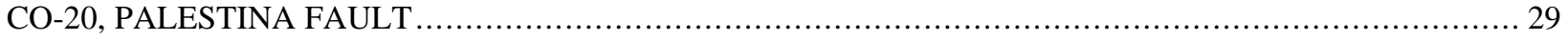

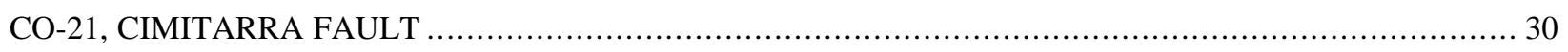

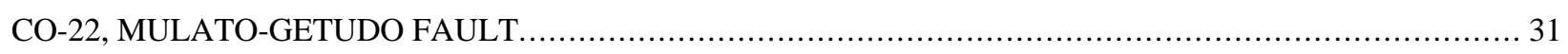

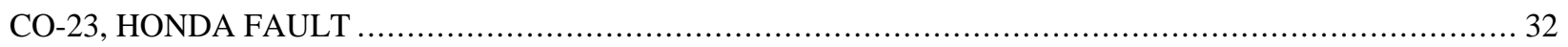

CO-24, ALTO DEL TRIGO FAULT (PART OF SALINAS FAULT SYSTEM) ....................................... 32

CO-25, BITUIMA FAULT (PART OF SALINAS FAULT SYSTEM) ................................................... 33

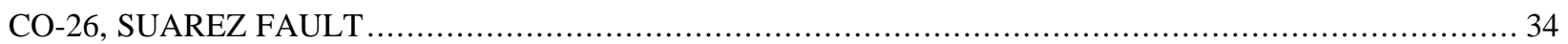

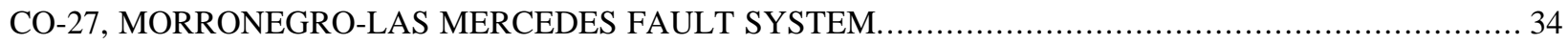

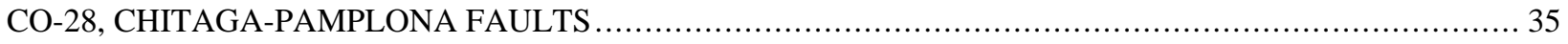

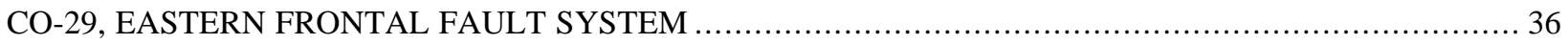

CO-29A, NORTHERN GUAICARAMO SECTION, EASTERN FRONTAL FAULT SYSTEM ..................................... 37

CO-29B, CENTRAL GUAICARAMO SECTION, EASTERN FronTAL FAULT SYSTEM ........................................... 37

CO-29C, SOUTHERN GUAICARAMO SECTION, EASTERN FRONTAL FAULT SYSTEM ...................................... 38

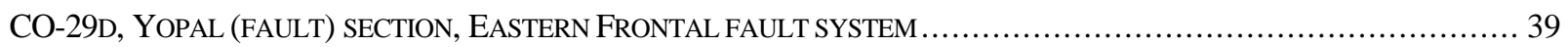

CO-29E, SAN PEDRo-CUMARAL (FAULT) SECTION, EASTERn FronTAL FAULT SYSTEM ................................ 40

CO-29F, SERVITA-SANTA MARIA (FAULT GROUP) SECTION, EASTERN FronTAL FAULT SYSTEM .......................... 40

CO-29G, GUAYURIBA (FAULT) SECTION, EASTERN FroNTAL FAULT SYSTEM .......................................... 41

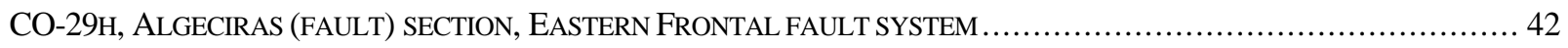

CO-29I, GARZON-PITALITO (FAULT) SECTION, EASTERN FroNTAL FAULT SYSTEM......................................... 43

CO-29J, SUAZA (FAULT) SECTION, EASTERN FRONTAL FAULT SYSTEM ............................................ 44

CO-29K, MOCOA (FAULT) SECTION, EASTERN FRONTAL FAULT SYSTEM................................................. 44

CO-29L, SiBUNDOY (FAULT) SECTION, EASTERN FrONTAL FAULT SYSTEM ........................................... 45

CO-29M, AFILADORES (FAULT) SECTION, EASTERN FronTAL FAULT SYSTEM....................................... 46

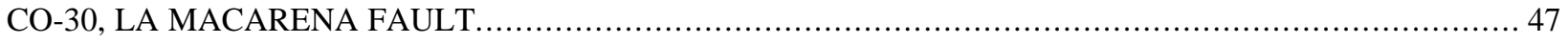

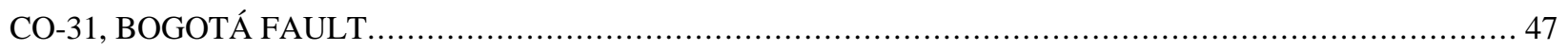

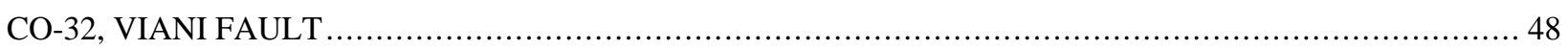

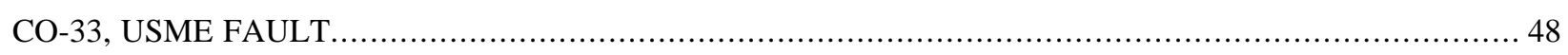

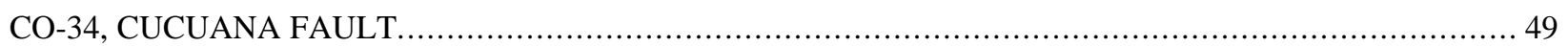

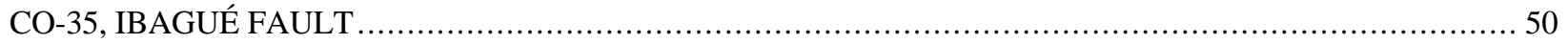

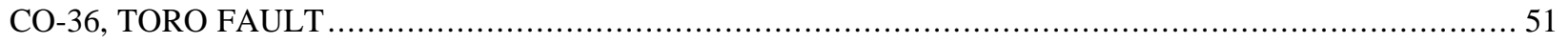

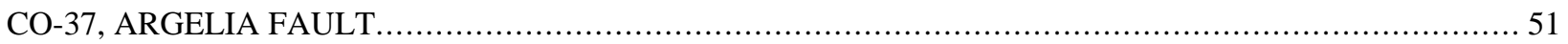

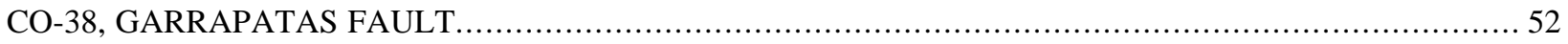

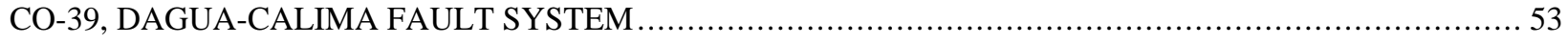

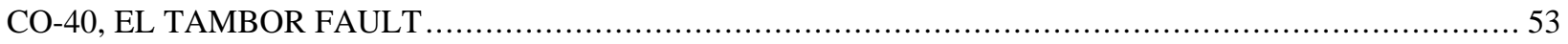




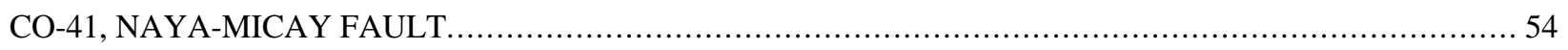

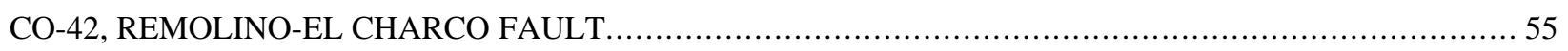

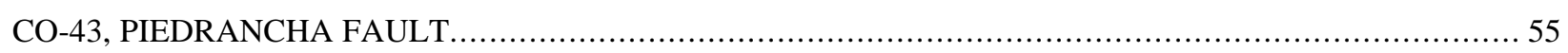

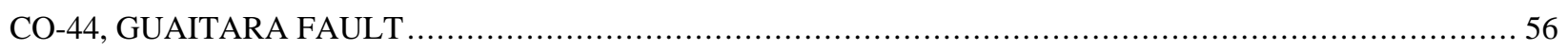

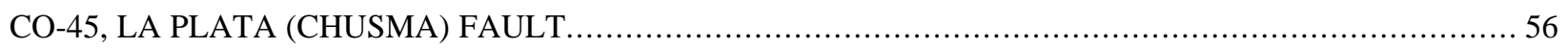

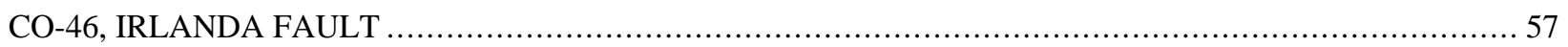

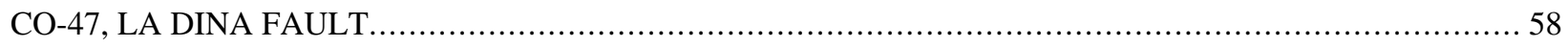

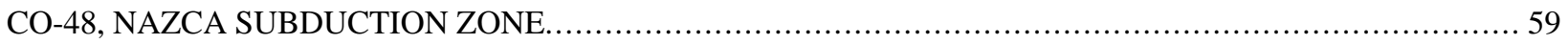

CO-49 SOUTH CARIBBEAN DEFORMED BELT (COLOMBIA FAULT) ...................................60 


\section{INTRODUCTION}

As part of the International Lithosphere Program's "World Map of Major Active Faults," the U.S. Geological Survey (USGS) is assisting in the compilation of a series of digital maps of Quaternary faults and folds in Western Hemisphere countries. The maps show the locations, ages, and activity rates of major earthquake-related features such as faults and fault-related folds. They are accompanied by databases that describe these features and document current information on their activity in the Quaternary. Top date, the project has published fault and fold maps for Costa Rica (Montero and others, 1998), Panama (Cowan and others, 1998), Venezuela (Audemard and others, 2000), Bolovia/Chile (Lavenu, and others, 2000), and Argentina (Costa and others, 2000). The project is a key part of the Global Seismic Hazards Assessment Program (ILP Project II-0) for the International Decade for Natural Hazard Disaster Reduction.

The project is sponsored by the International Lithosphere Program and funded by the USGS's National Earthquake Hazards Reduction Program. The primary elements of the project are general supervision and interpretation of geologic/tectonic information (Michael N. Machette, Project Chief), data compilation and entry for fault catalog (all personnel), database design and management (Kathleen M. Haller), and digitization and manipulation of data (Richard L. Dart) in ${ }^{\dagger}$ ARCINFO. For the compilation of data, we engage experts in Quaternary faulting, neotectonics, paleoseismology, and seismology. These experts are the primary authors of this report, and questions about individual fault descriptions should be directed to them. Questions about the project, its status, and the GIS map should be directed to the USGS authors.

Prior to initiating this project, a digital map of active or Quaternary faults did not exist for Colombia or any other country within South America, even though understanding the extent and character of active and older Quaternary faults are critical elements of seismic hazards analysis. Creation of this map and the accompanying database will help extend the relatively short record of instrumental and felt seismicity in Colombia by creating a map showing the major active faults of the region.

Although basic fault data were available for most of the country, the degree of completeness varies greatly and often is a function of the degree of remoteness and vegetation cover. A few faults have been the subject of recent investigations involving modern paleoseismic techniques (see for example references by Page and Woodward-Clyde Consultants). Other regions and faults have been studied in some detail, usually in association with concerns about hazards to urban areas or the safety of critical facilities such as lifelines, oil-and-gas pipelines, or power-generating facilities. Thus, considerable effort was required from the primary author (Gabriel Paris) to compile information from a wide variety of sources and insure that the national product is up to date and provides fairly uniform coverage for the entire country. Nevertheless, the general state of knowledge for faulting in Colombia is probably best described as being of a reconnaissance nature. A modest amount is known about the overall rates of fault activity and fault chronology-information that is difficult to acquire but critical to seismic hazard assessments. Hopefully, additional paleoseismic studies will help augment this map and database.

\section{STRATEGY AND PURPOSE}

For the map of Colombia, we relied on known, productive experts with strong local or regional knowledge of Colombia who were willing to participate in this international project. Given the limited time to produce the map (several years), the project was restricted to compilation of just those elements needed for ILP's Global Seismic Hazards Assessment Program (see database). We anticipate that the project will point out the shortcomings of past and current research on Quaternary faulting in Colombia in terms of quantity, quality, scope, and regional coverage and should help promote new efforts to collect paleoseismological data in previously neglected or known critical areas.

In many cases, seismicity is used to define some potentially active faults, especially along active plate margins. However, recent faulting events in the Western Hemisphere have shown that much of the faulting away from active plate margins occurs along faults with no significant level of seismicity and that only a fraction of active faults are characterized by ongoing seismicity. Thus, the information on Quaternary

\footnotetext{
${ }^{\dagger}$ Any use of trade names (such as this and others in the report) does not imply endorsement by the U.S. Geological Survey.
} 
faulting included within this database should help extend the modern (past several hundred years) record of seismicity into prehistoric time, and allow better assessments of active and potentially active faults in Colombia and other Western Hemisphere countries.

\section{TECTONIC SETTING}

Because of its position in the northwestern corner of South America, Colombia is tectonically controlled by the interaction of the Caribbean, South American, and Nazca plates, all of which converge or slip past one another. As a consequence of the tectonic evolution of the country, mainly during late Tertiary and early Quaternary times, two principal physiographic provinces have formed in Colombia. The first province is the eastern Llanos Plain, which is characterized by low, flat relief; they are part of a stable sialic shield formed of Precambrian age (1780 to $1450 \mathrm{Ma}$ ) migmatitic and high-grade metamorphic rocks (Priem 1979; Kroonenberg, 1980). The second province is the called the Andean belt, which is a deformed, faulted and folded tectonic belt composed of Precambrian to Tertiary continental rocks and Cretaceous oceanic rocks (Barrero, 1979; Paris and Marin, 1979; Restrepo and others, 1982; McCourt and Aspden, 1983; Duque-Caro, 1984; Brook, 1984; and Marin-Rivera, 1986). In addition to these provinces, there are extensive flat sediment-covered plains along the Caribbean and Pacific coasts.

The Andean belt is composed of three mountain ranges: Cordillera Occidental (Western), Central, and Oriental (Eastern). There are several positive topographic features isolated from the main Andean mountain system: they include the Sierra Nevada of Santa Marta, part of the Guajira Mountains, and the Serrania of La Macarena.

The large generally N-S to N-E-trending fault systems of the Cordilleras Central and Occidental probably developed since the Paleozoic with the westward continental accretion of exotic terrains from the ancient Pacific rise (spreading center). This accretion was induced by subduction of the Farallon Plate, which split into the Cocos and Nazca Plates during the Tertiary. Both of these plates are now being thrust beneath the Pacific coast of Panama and Colombia. Caribbean plate movement (Dunkan and Hargraves, 1984; Jordan, 1975; Sykes and others, 1982) and the accretion of the Panama-Choco block (DuqueCaro, 1980), an exotic piece of Central America, to northwestern Colombia, which was thrust southeastward during the Cenozoic, apparently are responsible for most of the Neogene geologic structures and active tectonic belts of the country. The accretion of the Panama-Choco block is contemporary with the onset of the mayor "Andean" tectonic phase which began 10.5 my ago and continued during Pliocene-Quaternary time (Kellogg and Vega, 1995).

The eastward subduction of the Nazca plate (Case and others, 1971; Londsdale and Klitgord, 1978; Pennington, 1981) induces most of the deep seismicity along the present Wadaty-Benioff zone and caused the Cenozoic magmatism and volcanism that is still occurring in the Cordilleras Central and Occidental. Conversely, southeastward subduction of the Caribbean plate (Kellogg, 1983) beneath the northern margin of Colombia is a nonmagmatic (shallow) process and is associated with low seismicity. East of the Andean belt, the South American plate pushes south-westward against the North Andes block resulting in thrusting of the Cordillera Oriental over the ancient Llanos shield crust in a typical foreland fold and thrust belt setting causing shallow but moderate to high levels of seismicity (Robertson, 1989).

The interaction of the three plates causes striking regional differences in the sense of movement of active faults. The principal compressive stress vectors in Colombia are NW-SE in the northern Andean region and E-W to NE-SW in the southern Andean region. Acting on generally N-S trending faults (major faults), these stresses induce sinistral (left-lateral) movement on the faults located to the north and dextral (right-lateral) movement on faults located to the south in both the Western and Eastern Andean region, in addition to whatever reverse or normal displacement can take place as a result of oblique compression (Paris and Romero, 1994). The paleo-Caribbean plate convergence and subduction beneath the Andes block acts like a continental wedge plunging toward the ESE, limited to the northeast by the NNW trending Bucaramanga sinistral fault $[\mathrm{CO}-2 \mathrm{~b}]$ and to the south by the general $\mathrm{E}-\mathrm{W}$ trending Garrapatas [CO-38] and Ibague [CO-35] dextral faults. Progressive indentation of the wedge is absorbed along reverse faults in the foothills of the cordilleras northward of $5 \circ \mathrm{N}$, and transpressive deformation in the Santander Massif. Intermediate seismicity beneath the Cordillera Oriental is associated with the remnant of the paleo-Caribbean subducted plateau as suggested by tomographic profiles (Taboada and others, 2000). 


\section{MAJOR STRUCTURAL ELEMENTS AND RECENT EARTHQUAKES}

Much of the crustal seismicity in Colombia is accurately correlated with active faults and deformation showing neotectonic features. Of the active fault systems, the Romeral fault system [CO-15] and Eastern Frontal fault system [CO-29] are the most active seismically (see accompanying plate). The Romeral fault system (McCourt and Aspdem, 1983; Hutchings and others, 1981) extends along the westwern slope of the Cordillera Central: it separates accreted oceanic rocks to the west from a domain of continental rocks to the east. It appears to be the reactivation of a much older suture zone that over considerable length has the characteristicas of an ophiolitic belt. The young volcanic chain along the crest of the Central Andean Range is just east of the Romeral fault system. Conversely, the Eastern Frontal fault system (Aggarwal, 1983; Sarria, 1990) marks the active underthrusting of the Cordillera Oriental by the Precambrian shield (Paris y Sarria, 1986; AIS and others, 1996) in a typical foreland fold and thrust belt setting. The sense of movement along the Eastern Frontal fault system varies from predominantly low-angle thrusting in the north to almost pure dextral slip along vertical fault planes much farther to the south. It is considered to be the southwest extension of the Bocono fault system [VE-06] Venezuela and continues farther to the south through Ecuador to meet the Gulf of Guayaquil at the Pacific. Several authors consider it to be the actual western Quaternary boundary of the South American plate in this northwest corner of the continent. Together, the Romeral and Eastern Frontal fault systems are the most active seismic sources in the country, being driven by active subduction processes in a multiple plate interaction situation.

In northeastern Colombia, the Santa Marta-Bucaramanga fault [CO-02] displays the most prominent morphotectonic features (Paris y Sarria, 1986) with primarily sinistral movement and uplift of the Sierra Nevada de Santa Marta to the east. The Oca fault [CO-01, VE-01; Audemard and others, 2000] is the main E-W trending fault that bounds the northern margin of the Sierra Nevada de Santa Marta and the Caribbean Sea. Although considered to be a mainly Pliocene structure when it was the boundary between the Caribbean and South American plates, it is still relatively active.

Several historical earthquakes associated with crustal faults have taken place in Colombia. During the 20th century the largest was the 1908 Tumaco earthquake (an offshore subduction event), which at M 8.9 is one of the largest magnitude earthquakes in the world. In the past 25 years, there have been a series of locally damaging earthquakes that include the 1979 Bahia Solano (M 6.5), the 1983 Popayan (M 5.2), the 1992 Murindó (M 7.2), the 1995 Tauramena (M 6.5), the 1994 Paez (M 6.4), and the 1999 Armenia (M 6.2) earthquakes, all of which were rather shallow and caused substantial loss of life and severe damage to communities. Some events were associated with small surface displacements.

\section{PREPARATION OF THE DATABASE AND MAP}

This compilation shows evidence for activity of Quaternary faults and folds in Colombia and its offshore regions of the Caribbean Sea and Pacific Ocean. The data were compiled initially for this project during 1993 while the senior author was employed by INGEOMINAS in Bogotá. The data and map were reviewed and revised in 1997 and released as the Neotectonic Map of Colombia (Paris and others, 1997). This map and the accompanying data were revised by the senior author in 1998-2000 after retiring from INGEOMINAS. Gabriel Paris used available published and unpublished literature, recent geological investigations, and interpretation of aerial photographs and satellite imagery to revise earlier mapping. The surface traces of the Quaternary faults and folds were compiled on a planimetric base map at a scale of 1:1,500,000. Offshore traces were supplied by Michael Machette from a variety of sources and are based primarily on marine geophysical studies and bathymetric maps; these traces are inherently less well defined and located, and should be considered approximate. Machette edited the text and map data and provided guidance for the project under the International Lithosphere Program's Task Group II-2 "Major Active Faults and Folds of the World," for which he is the Co-chairman (Western Hemisphere).

Richard Dart and Jonathan Cox used GIS (Geographic Information System) technology to produce the fault and fold maps. The traces of Quaternary faults and folds were digitized, attributed for age, sense of slip, and line type (continuous, discontinuous, and concealed or inferred), and transformed using a Mercator projection. The maps were prepared with ARC/INFO version 7.1.2 running under Solaris version 2.5.1 on a Unix workstation. The GIS data is scale independent but should not be used at scales greater 
(more detailed) than about 1:1,000,000 (twice the digitized scale). Data for the fault length and average strike were generated from the ARC/INFO files.

The base-map information for the enclosed map was taken from the Digital Chart of the World, which was created for use with ARC/INFO (copyright 1993 by the Environmental Systems Research Institute, Inc.). The Digital Chart of the World was compiled at a scale of 1:1,000,000, which is 150 percent of the scale of the digitized fault map $(1: 1,500,000)$. The Digital Chart of the World was originally developed for the United States Defense Mapping Agency (DMA) and is primarily derived from the DMA Operational Navigation Chart (ONC) Series.

\section{AP}

The map of Quaternary faults and folds (see attached plate) of Colombia was compiled on and digitized from a base map at 1:1,500,00 scale (INGEOMINAS, 1988). Although unspecified, the map has been produced using a Mercator projection. The scale of the source map allows output as a single-country map $(1: 1,000,000$ to $1: 2,000,000$ scale) while retaining all significant digital information, output at provincial and regional scales (1:200,000 to $1: 500,000$ scale) will magnify errors in the location and depiction of faults and folds, and should only be done with appropriate caution. In addition to fault location and style, the map shows time of most recent movement and estimates of slip rate (as a proxy for fault activity).

Although as many as five categories of Quaternary faults can be depicted on the Western Hemisphere maps, only three categories were used in Colombia:

Historic (generally $<200$ years),

Holocene and latest Pleistocene ( $<15,000$ years or $<15 \mathrm{ka})$,

Quaternary $(<1,600,000$ years or $<1.6 \mathrm{Ma})$.

Categories for the late Quaternary ( $<130 \mathrm{ka})$ and late and middle Quaternary ( $<750 \mathrm{ka}$ ) were not used owing to the general lack of stratigraphic and chronological control needed to make these age

differentiations. This categorical time scheme allows some flexibility in reporting between countries owing to the differing levels of investigation and abilities to date prehistoric faulting.

We have four ranges (categories) of slip rates that can be depicted by line thicknesss on the map in order to differentiate known rates of fault activity. Onland in Colombia, no faults have been shown to have $>5 \mathrm{~mm} / \mathrm{yr}$ rates. However, the Bocono fault in Venezuela (VE-06, about $8 \mathrm{~mm} / \mathrm{yr}$ ) and the offshore Nazca subduction zone [CO-48, $70 \mathrm{~mm} / \mathrm{yr}$ ] and South Caribbean deformed belt [CO-49, $10 \mathrm{~mm} / \mathrm{yr}$ ] all have cumulative slip rates that exceed $5 \mathrm{~mm} / \mathrm{yr}$.

$>5 \mathrm{~mm} / \mathrm{yr}$-Plate-boundary faults and subduction zones (very high slip rates, no in Colombia), 1-5 mm/yr - Lesser strike-slip and major extensional faults (medium to high slip rates),

1-0.2 $\mathrm{mm} / \mathrm{yr}$-Many extensional and intraplate faults (low to medium slip rates), and

$<0.2 \mathrm{~mm} / \mathrm{yr}$-Most extensional faults (very low to low slip rates).

Actual slip rate determinations or estimates are sparse in Colombia, but in many cases the senior author specified a low or low to medium rate. In these cases, we have depicted slip rate using the above guidelines. Most faults in Colombia with "unknown slip rates" (see table on map) are designated as medium to low $(0.2-1.0 \mathrm{~mm} / \mathrm{yr})$ or very low $(<0.2 \mathrm{~mm} / \mathrm{yr})$ based on the faults expression or similarities with other faults in the region.

\section{DATABASE}

The purpose of the database is to provide large quantities of fault data that can be readily accessed using a variety of search parameters. For this database, we anticipate that the user would want search-andretrieve capabilities from a personal computer. The user may want to sort the data by such parameters as fault name, time of most recent movement (one of three categories), slip rate (one of four categories), sense of movement, or by multiple parameters.

The process of data compilation starts with data acquisition and synthesis. In the case of faults, the compiler must determine if the structure is a simple one, or if it qualifies as having sections (increasing complexity of geometry or fault history). Then using the appropriate form, the compiler tabulates information on the fault's parameters. The forms were built in Microsoft Word for the Macintosh. 
After this report is released, we will incorporate suggested changes and additions; then import the data to the computer database. Each of the fields is a potential search object. The use of a computer database program allows us to custom format the reporting of data and to collapse unused fields or notes. The basic fields are restricted to 256 characters, but we use the note option for more explanatory information (shown under comments in this report).

The fault and fold data will be released in several forms. This open-file report constitutes a traditional hard-copy catalog (database and map) for Colombia. The Colombian data will eventually be part of a larger relational computer database for the Western Hemisphere that should be available on the World Wide Web (WWW). This interactive WWW product allows the user to browse, sort, and print the data. However, we do not anticipate allowing the database to be altered using only the run-time WWW version of the database program.

\section{DEFINITION OF DATABASE TERMS}

The following terms provide data for specialized fields, most of which will be searchable when the computer database is released. In addition to the searchable fields, more detailed information is provided in the "Comments" section that follows some fields. If a field is empty or has been deleted, no pertinent information was found in the published literature. The following description provides definitions of fields (in alphabetic order) and indicates where various information, if known, can be found. Citations of references are in a traditional (USGS) format, although foreign language citations are as provided by the compilers (and shown in italics).

Average dip: General down-dip direction of the structure where known.

Average strike: The length-weighted average strike of the fault trace is reported in the northwest and northeast quadrants of the compass (i.e., $-30^{\circ}$ is N. $30^{\circ} \mathrm{W}$., versus $30^{\circ}$ which is N. $30^{\circ} \mathrm{E}$. The value (i.e., $\pm 30^{\circ}$ ) that follow the strike describe the range for all vectors contained with the trace of that particular fault or collection of faults. These values are included only to provide a general impression of the sinuosity or variability in strike of the mapped structures. Some fault zones include faults with a wide variety of strikes, and thus \pm values are large.

Compiler, affiliation and date of compilation: The name and affiliation of the person(s) primarily responsible for compilation or update of data presented for the structure. Also shown is the date when data were compiled for this project (e.g., January 1997).

Fault geometry: This includes geographic information pertinent to the fault or fault being described. The data include length, average strike, average dip, and sense of movement.

Fault/fold name (see Name)

Fault/fold number (see Number)

Geomorphic expression: General description of the structure's geomorphic expression including information on the the presence or absence of fault scarps, offset streams, monoclines, shutter-ridges, associated landslides, etc.

Historical surface faulting: When the timing of most recent movement is historic, then this field(s) describes evidence for surface faulting associated with historical earthquakes. Also included is seismological information for the historical earthquake.

Length: This field specifies the end-to-end length of the Quaternary-age fault (or fault section) as measured from the most distal ends of the trace. The ends of overlapping or echelon traces are projected to a line defined by the average strike and the length is then determined from those projected end points. Also shown (in parentheses) is the cumulative length of all surface traces included in the fault, fault zone, or collection of faults. The cumulative length can differ considerably from the end-to-end length.

Name (Fault name or Section name): The earliest referenced name for a structure, fault segment or fault section (where appropriate) generally is given preference, except in cases where a more commonly accepted name is widely used in the recent literature. "Comments" also contains other names and references in which they are used, the geographic limits of the structure, north to south or west to east, as shown in this compilation; various geographic limits that are different in other studies are also included. Minor changes in original name may have been made for reasons of clarity or consistency 
(such as segment to section) where appropriate. We have found no faults in Colombia that justify using the term "segment", owing to a lack of precise timing information.

\section{Number:}

Structure number: The structure (fault or fold) is assigned a number that is preceded by a two character abbreviation (PA, Panama; CO, Colombia; etc.) that is unique to each of the countries in the Western Hemisphere. For the sake of clarity, the CO- designator is not used on the national map of Colombia, but is used on the small inset area that includes Bogotá. References to the same structure shown in other compilations, such as CR-50 and PA-12 are included in "Comments".

Section number: An alpha character is assigned to the northernmost or westernmost section of a fault (e.g., fault CR-07 has four sections: CO-7a, -07b, -07c, and -07d).

Number of sections: (only used for faults with sections) Numeric value for number of sections (e.g., 4) defined in studies that do not meet the minimum requirements for segments established for this compilation. "Comments" include reference in which sections are discussed; if the term "segment" is used in the literature, an explanation of why "section" is used in the database is provided.

Recurrence interval: Time interval in yr (based on historic data, calendric or calibrated radiocarbon dates), in ${ }^{14} \mathrm{C}$ yr (based on uncalibrated radiocarbon dates), or in k.y. (thousand years, based on less precise dating methods, stratigraphy, or geomorphology). Unknown is shown if there is no published recurrence interval value. Also included is the time interval (in parenthesis) for which this recurrence interval is valid. (e.g., 10-130 k.y.) Alternative published recurrence intervals, starting with that which applies to the most recent time interval, are included in "Comments. "

References: A bibliographic citation is included for all references pertinent to each structure.

Section: A geographic, geometric, structural portion of a fault or collection of faults that appear(s) to have a different character than adjacent portions of the fault (or fold). Typically, not enough information exists to show that this portion of the fault acts independently of adjacent portions, and thus does not qualify as a bona fide "segment" of a fault in a paleoseismic sense. There are no known faults with proven segments in Colombia, although several faults are described as having sections. Further research is needed to document additional faults with sections or those with sections that may be segments.

Section name (see Name)

Section number (see Number)

Sense of movement: Includes thrust, less than $45^{\circ}$ dip; reverse, greater than $45^{\circ}$ dip; right-lateral strike slip (dextral); left-lateral strike slip (sinistral ); or normal. For oblique slip, the principle sense of movement is followed by secondary sense.

Slip rate: The primary field shows an actual value or one of several slip-rate categories used for the map part of this compilation: $<0.2 \mathrm{~mm} / \mathrm{yr}, 0.2-1 \mathrm{~mm} / \mathrm{yr}, 1-5 \mathrm{~mm} / \mathrm{yr}$, or $>5 \mathrm{~mm} / \mathrm{yr}$. "Unknown" precedes the suspected slip-rate or slip rate category if no published slip rate is known. "Comments" may include a synopsis of published slip rates and pertinent documentation. Generally speaking, there are two types of slip rates. The first type is termed a "Geologic slip rate" and is derived from the age and amount of offset of surficial geologic deposits. These rates are not precise, but allow one to place broad limits on possible slip rates, and hence characterize the fault in one of the above-mentioned categories. The second type of slip rate is termed a "Paleoseismic slip rate" and is derived from times of faulting events and amounts of offset of geologic datums or piercing point. This type of slip rate is more precise, but is rare owing to the extensive amount of work involved (i.e., detailed paleoseismologic studies involving trenching and numeric dating).

Synopsis and geologic setting: This field provides a short summary that describes the level of study, provides a snapshot of the scope of data that follows in the database and provides a generalized perspective of the fault in terms of its regional geologic setting, amount of total offset, and general age of offset strata

Timing of most recent event (faulting or folding event): The primary field shows one of the two prehistoric time categories: latest Quaternary (Holocene and latest Pleistocene, $<15 \mathrm{ka}$ ) or Quaternary $(<1.6 \mathrm{Ma})$. This field may document historic surface faulting, although details of the earthquake related to the faulting will follow.

Type of studies: This field briefly summarizes the types of studies conducted on the fault. 


\section{ACKNOWLEDGEMENTS}

This project was supported by the USGS's National Earthquake Hazards Reduction Program (NEHRP) and by the International Lithosphere Program (ILP) under Task Group II-2. Gabriel Paris's initial (1993) compilation was conducted as an employee of INGEOMINAS (Instituto Nacional de Investigaciones Geologico-Mineras); more recent descriptions and modifications were conducted on his own time. Compilation of the early version of the map (1993) was performed with the help of Jaime Romero from INGEOMINAS, latter digitalization and completion was carried out with the help of Claudia L. Hurtado and Haxia Martinez, sponsored by the Corporacion Autonoma del Quindío (CRQ) and the Universidad del Quindío. We appreciate the careful review and constructive comments provided by William Page of Pacific Gas and Electric Company (San Francisco, California), who worked in the region for Woodward-Clyde Consultants in the 1980's. Hans Diederix (formerly of the International Institute for Aerospace Survey and Earth Sciences (ITC), Enschede, The Netherlands) reviewed a second version of the map and database and provided additional suggestions-we appreciate his efforts on the part of ILP II-2.

\section{REFERENCES CITED}

(References published in Spanish are shown in italics)

Aggarwal, Y., 1983, Seismic slip rates and earthquakes ruptures zones in the southern Caribbean: Implications for plate motions and earthquake hazard in this region (abstract): Abstracts $10^{\text {th }}$ Caribb. Geol. Conf., $16 \mathrm{p}$.

Asociación Colombiana de Ingeniería Sísmica (AIS), 1996, INGEOMINAS—Uniandes, Estudio general de la amenaza sísmica en Colombia: INGEOMINAS, Bogotá, 254 p.

Audemard, F.A., Machette, M.N., Dart, R.L., and Haller, K.M., 2000, Map and Database of Quaternary Faults in Venezuela and its Offshore Regions: U.S. Geological Survey Open-File Report 00-018, 76 p., 1 plate (1:2M scale).

Barrero, D., 1979, Geology of the Central Western cordillera, West of Buga and Roldanillo, Colombia: INGEOMINAS, Pub. Geol. Esp. 4, 75 p.

Brook, H., 1984, New radiometric age data from S.W. Colombia: INGEOMINAS-Misión Británica (British Geological Survey), Report No. 10, 25p.

Case, J.E., Duran, L.G., Lopez, R.A., and Moore, WR., 1971, Tectonic investigatios in western Colombia and eastern Panama: Geological Society of America Bulletin, v. 82, p. 2685-2711.

Costa, C., Machette, M.N, Dart, R.L., Bastias, H.E., Paredes, J.D., Perucca, L.P., Tello, G.I., and Haller, K.M., 2000, Map and Database of Quaternary Faults and Folds in Argentina: U.S. Geological Survey Open-File Report 00-0108, 76 p., 90 p., 1 plate (1:4,000,000 scale).

Cowan, H., Machette, M.N., Haller, K.M., and Dart, R.L., 1998, Map and database of Quaternary faults and folds in Panama and its offshore regions: U.S. Geological Survey Open-File Rpt. 98-779, 41 p., 1 plate (1:500K scale).

Dunkan, R.A, and Hargraves, R.B., 1984, Plate tectonic evolution of the Caribbean regions in the mantle reference frame, in Bonnini, R.B., Hardgraves, R.B. and Shagan, R. (eds.), The Caribbean-SouthAmerican plate boundary and regional tectonics: Geological Society of America Memoir 162, p. 81-84.

Duque-Caro, H., 1980, Geotectónica y evolución de la región noroccidental de Colombia: Boletin Geológico INGEOMINAS, Bogotá, v. 23, no.3, p. 4-37.

Duque-Caro, H., 1984, Structural style, diapirism, and accretionary episodes of the Sinú-San Jacinto terrane, southwestern Caribbean borderland, in Bonnini, R.B., Hardgraves, R.B. and Shagan, R. (eds.), The CaribbeanSouthAmerican plate boundary and regional tectonics: Geological Society of America Memoir 162, p. 303-316.

Espinosa, A., 2001, Estudio de la actividad de la falla de Armenia: Convenio CRQ-Uniquindío, Universidad del Quindío Facultad de Ingeniería, Informe Final, Armenia ,19 p. (Inédito)

Hutchings, L., Torcotte, T., McBride, J., Y Rocha, H., 1981, Microseismicity along and near the Dolores shear zone in Antioquia, Colombia: Memorias I Seminario sobre el Cuat. de Colombia: Revista CIAF, v. 6, no. 1-3, p. $243-285$.

Jordan, T.H., 1975, The present-day motions of the Caribbean Plate: Journal Geophy. Res., v. 80, p. 4433-4449.

Kellogg, J., Godley, V., Ropain, C., and Bermudez, A., 1983, Gravity anomalies and tectonic evolution of northwestern South America: Memoir 10th Caribbean Geological Conference, p. 18-31.

Kellogg, J., and Vega, V., 1995, Tectonic development of Panama, Costa Rica and Colombian Andes: Constrains from Global Positioning System geodetic studies and gravity: Geol. Soc. Am. Spec. Paper 295, p. 75-90.

Kroonenberg, S., 1980, Petrografía y edad de algunos neises cordieríticos del Guainía, Amazonia Colombiana: Revista CIAF, v. 5, p. 213-218.

Lonsdale, P., and Klitgord, K.D., 1978, Structure and tectonic history of the eastern Panama Basin: Geological Society of America Bulletin, v. 98, p. 981-999. 
Marin-Rivera, P., 1986, Configuración tectono-estratigráfica de las diferentes épocas metalogenéticas colombianas: INGEOMINAS, Bogotá (Informe no publicado), 29 p.

McCourt, W., and Aspden, J., 1983, Modelo tectónico de placas para la evolución fanerozoica de Colombia central y sur: INGEOMINAS-Misión Británica, Cali, $23 p$.

Nivia,A., Marriner, G., and Kerr, A.,1996, El Complejo Quebradagrande una posible cuenca marginal intracratonica del Cretaceo inferior en la cordillera de los Andes Colombianos: VII Congreso Colombiano de Geología, III, 108-123, Bogotá.

Montero, W., Denyer, P., Barquero, R., Alvarado, G.E., Cowan, H., Machette, M.N., Haller, K.M., and Dart, R.L., 1998, Map and database of Quaternary faults and folds in Costa Rica and its offshore regions: U.S. Geological Survey Open-File Report 98-481, 63 p., 1 plate (1:750K scale).

Paris, G., and Marin, P., 1979, Generalidades acerca de la geología del Departamento del Cauca: INGEOMINAS, Popayán, $38 p$.

Paris, G., y Romero, R., 1994, Fallas Activas en Colombia: INGEOMINAS, Santafé de Bogotá, Bol. Geol., v. 34, no. 2-3, p. 3-26.

Paris, G., y Sarria, A., 1986, Proyecto geofísico del nordeste Colombiano: Informe INGEOMINAS-ISA, Bogotà, 59 p.

Pennington, W.D., 1981, Subduction of the eastern Panama basin and the seismotectonics of northwestern South America: Journal of Geophysical Research, v. 86, p. 10753-10770.

Priem, H.N.A., 1979 Isotopic dating in the complejo migmatitico de Mitú: Interin report, PRORADAM/ZWO laboratorium ror Isitopengeologie, $5 \mathrm{p}$.

Ramirez, J E., 1975, "Historia de los Terremotos de Colombia”: Seg. Ed. Instituto Geografico Agustin Codazzi, 250 p., Bogotá

Restrepo, J.J., y Toussaint, J.F., 1982, Metamorfismos sobrepuestos en la Cordillera Central de Colombia: V Congr. Latino-amer. Geol. Mem. Argentina, v. 3, p. 505-512.

Robertson, K., 1989, Actividad neotectónica en el piedemonte de la Cordillera Oriental, sector VillavicencioTauramena, Colombia: V Congr. Col. Geol. Mem., v. 1, p. 171-192.

Sarria, A., 1990, Ingenieria Sismica: Universidad de los Andes, Bogotá, 610 p.

Sykes, L.R., McCann, W.R., and Kafka, A.L., 1978, Motion of the Caribbean plate during last 7 millon years and implications for earlier Cenozoic movements: Journal of Geophysical Research, v. 87, p. 10656-10676.

Taboada, A., Rivera, L. A., Fuenzalida, A., Cisternas, A., Philip, H., Bijwaard, H., Olaya, J., and Rivera, C., 2000, Geodinamics in northern Andes: Subductions and intracontinental deformations (Colombia), Tectonics, v. 19, p. 787-813.

Lavenu, A., Thiele, R., Machette, M.N., Dart, R.L., and Haller, K.M., 2000, Map and Database of Quaternary Faults and Folds in Bolovia and Chile: U.S. Geological Survey Open-File Report 00-0283, 38 p., 2 plates

Tibaldi, A., and Romero, J., 2000, Morphometry of late Pleistocene-Holocene faulting and volcanotectonic relationship in the southern Andes of Colombia: Tectonics, v. 19, p 358-377. 


\section{DATABASE OF FAULTS AND FOLDS}

\section{CO-01, OCA FAULT}

FAULT NUMBER/NUMERO DE LA FALLA: CO-01

FAULT NAME/NOMBRE DE LA FALLA: Oca

SYNOPSIS AND GEOLOGIC SETTING/SINOPSIS Y AMBIENTE GEOLOGICO: The Oca fault bounds the northern margin of the Sierra Nevada de Santa Marta along the coast of the Caribbean Sea between the cities of Rioacha and Santa Marta. To the east, the fault cuts the Serranía de Perijá and extends more than $560 \mathrm{~km}$ across Venezuela [Oca-Ancon fault, VE-01a; Audemard and others, 2000], separating the coastal plains to the north from the Maracaibo Basin to the south. The fault places Paleozoic and Mesozoic rock (Santa Marta Massif) against Tertiary rocks and late Quaternary sediment. It is believed to be have been the boundary between the Caribbean and South American plates during Tertiary time.

COMPILER, AFFILIATION, \& DATE OF COMPILATION/COMPILADOR, AFILIACION Y FECHA DE COMPILACION: Gabriel Paris, INGEOMINAS, Bogotá; October 1993.

TYPE OF STUDIES/TIPOS DE ESTUDIOS: Interpretation of aerial photographs and reconnaissance field studies.

GEOMETRY OF THE FAULT/GEOMETRIA DE LA FALLA: LENGTH/LONGITUD: $265 \mathrm{~km}$ (267 km cumulative) Comments/Comentarios: These lengths are for the portion of the fault in Colombia. This fault extends another $563 \mathrm{~km}$ eastward into Venezuela [VE-01], where it is divided into five sections.

AVERAGE STRIKE/RUMBO PROMEDIO: $-85.2^{\circ} \pm 7^{\circ}\left(\mathrm{N} 85.2^{\circ} \mathrm{W} \pm 7^{\circ}\right)$

Comments/Comentarios: GIS values for fault in Colombia only.

AVERAGE DIP/INCLINACION PROMEDIO: Unknown, probably vertical to subvertical. SENSE OF MOVEMENT/SENTIDO DE MOVIMIENTO: Dextral (right-lateral).

GEOMORPHIC EXPRESSION/EXPRESION GEOMORFOLOGICA: Very pronounced fault line trace on aerial photographs and satellite images. It forms a strong topographic break, has local fault scarps, and offsets Quaternary terraces to the southeast of the city of Rioacha.

RECURRENCE INTERVAL/INTERVALO DE RECURRENCIA: <10 k.y. Comments/Comentarios: Inferred from slip rate observed in trenches in Venezuela (Page, 1986).

SLIP RATE/TASA DE MOVIMIENTO: 0.2-1.0 mm/yr Comments/Comentarios: Slip rate of $0.2-0.8 \mathrm{~mm} / \mathrm{yr}$ calculated from slip rate observed in trenches in Venezuela (Page, 1986).

TIME OF MOST RECENT MOVEMENT/EDAD DEL ULTIMO MOVIMIENTO: <15 ka, possibly historic (1833 or 1834)

Comments/Comentarios: Movement since $15 \mathrm{ka}$, but there are some historic reports of earthquakes during 1833 or 1834 that were strong enough to have broken the tomb of Simon Bolivar at the cemetery of Santa Marta. However there is no evidence of surface rupture.

NAME OF EARTHQUAKE/NOMBRE DEL TERREMOTO: Earthquake (Terremoto) de 1834

DATE/FECHA: Probably 1833 or 1834.

MAGNITUDE OR INTENSITY/MAGNITUD O INTENSIDAD: Unknown

REFERENCES/REFERENCIAS

Audemard, F.A., Machette, M.N., Dart, R.L., and Haller, K.M., 2000, Map and Database of Quaternary Faults in Venezuela and its Offshore Regions: U.S. Geological Survey Open-File Report 00-018, 76 p., 1 plate (1:2,000,000 scale).

Espinosa, A., 1989, Hacia un Nuevo Catálogo Colombiano de Simicidad Histórica: Memorias V (5th) Congreso Colombiano de Geología, Tomo 1, Bucaramanga, 12 p.

Page, W.D., 1986, Geología Sísmica y Sismicidad del Noroccidente de Colombia: San Francisco, California, Woodward-Clyde Consultants unpublished report for Integral Ltda. and ISA, Medellín, p. 169-174.

Paris, G., y Romero, J., 1994, Fallas Activas en Colombia: INGEOMINAS, Boletin Geológico, v. 34, no. 2-3, p. 3-26 (Santafé de Bogotá). 


\section{CO-02, SANTA MARTA-BUCARAMANGA FAULT SYSTEM}

FAULT NUMBER/NUMERO DE LA FALLA: CO-02

FAULT NAME/NOMBRE DE LA FALLA: Santa Marta-Bucaramanga (fault system)

SYNOPSIS AND GEOLOGIC SETTING/SINOPSIS Y AMBIENTE GEOLOGICO: The Santa Marta-

Bucaramanga is a major fault system which extends for a distance of $550 \mathrm{~km}$ from the Caribbean coast to the Cordillera Oriental to as far as about $6.5^{\circ} \mathrm{N}$, south of the city of Bucaramanga. The fault is a major wrench fault with a sinistral (left-lateral) displacement of about $110 \mathrm{~km}$ (Campbell 1965). The Santa Marta fault forms the boundary between several distint geological provinces: it is the western limit of the Santa Marta massif and separates the Lower Magdalena basin from the Cesar basin and the Santander Massif from the Middle Magdalena Valley. It divides the northern part of the Cordillera Oriental in two structurally distint regions. The uplifted eastern block is mainly comprised of crystalline igneous and metamorphic rocks of Paleozoic and pre-Cambrian age, with lesser amounts of Jurassic, Triassic and Tertiary sedimentary rocks. In the western downthrown block there are predominately sedimentary rocks of Quatenary and Tertiary age, with lesser amounts of Cretaceous and Jurassic rocks. The northern half of the fault is partially covered by Quaternary and Holocene deposits in the Cesar and Magdalena valleys.

COMPILER, AFFILIATION, \& DATE OF COMPILATION/COMPILADOR, AFILIACION Y FECHA DE COMPILACION: Gabriel Paris, INGEOMINAS, Bogotá; November 1993. Reviewed January 1997 at CRQ and UNIQUINDIO, Armenia. Revised by Gabriel Paris, Estudios Geológico Mineros, Cali; June 1998.

TYPE OF STUDIES/TIPOS DE ESTUDIOS: Interpretation of aerial photographs and satellite images, general geologic reconnaissance, and neotectonic and morphotectonic field studies.

FAULT GEOMETRY/ GEOMETRIA DE LA FALLA: LENGTH/LONGITUD: $537.6 \mathrm{~km}$ (674.0 km cumulative) AVERAGE STRIKE/RUMBO PROMEDIO: $-19.1^{\circ} \pm 23^{\circ}\left(\mathrm{N} 19.1^{\circ} \mathrm{W} \pm 23^{\circ}\right)$

NUMBER OF SECTIONS/NUMERO DE SECCIONES: 2

\section{CO-2A, SANTA MARTA SECTION, SANTA MARTA-BUCARAMANGA FAULT SYSTEM}

FAULT SECTION NUMBER/NUMERO DE LA FALLA DE LA SECCION: CO-2a

SECTION NAME/NOMBRE DE LA SECCION: Santa Marta

GEOMETRY OF THE SECTION/GEOMETRIA DE LA SECCION:

LENGTH/LONGITUD: $374.1 \mathrm{~km}$ (366.5 km cumulative)

AVERAGE STRIKE/RUMBO PROMEDIO: $-20.9^{\circ} \pm 31^{\circ}\left(\mathrm{N} 20.9^{\circ} \mathrm{W} \pm 31^{\circ}\right)$

AVERAGE DIP/INCLINACION PROMEDIO: High to the east to vertical

Comments/Comentarios: Estimated from regional geomorphic expressión of fault trace.

SENSE OF MOVEMENT/SENTIDO DE MOVIMIENTO: Sinistral (left-lateral) and reverse Comments/Comentarios: East-side up.

GEOMORPHIC EXPRESSION/EXPRESION GEOMORFOLOGICA: A strong topographic lineament is easily seen on satellite images and aerial photographs. The trace of the fault is marked by abrupt changes in slope between the eastern side and western sides of the fault; sinistral (left-lateral) deflected streams are commonly seen.

RECURRENCE INTERVAL/INTERVALO DE RECURRENCIA: Unknown

SLIP RATE/TASA DE MOVIMIENTO: Unknown, probably $<0.2 \mathrm{~mm} / \mathrm{yr}$

TIME OF MOST RECENT MOVEMENT/EDAD DEL ULTIMO MOVIMIENTO: Probably Quaternary, <1.6 Ma Comments/Comentarios: Based on the strong linear and topographic features between old crystalline rocks and Neogene deposits.

\section{CO-2B, BUCARAMANGA SECTION, SANTA MARTA-BUCARAMANGA FAULT SYSTEM}

FAULT SECTION NUMBER/NUMERO DE LA FALLA DE LA SECCION: CO-2b

SECTION NAME/NOMBRE DE LA SECCION: Bucaramanga

GEOMETRY OF THE SECTION/GEOMETRIA DE LA SECCION:

LENGTH/LONGITUD: $229.8 \mathrm{~km}$ (307.5 km cumulative)

AVERAGE STRIKE/RUMBO PROMEDIO: $-17.1^{\circ} \pm 13^{\circ}\left(\mathrm{N} 17.1^{\circ} \mathrm{W} \pm 13^{\circ}\right)$

AVERAGE DIP/INCLINACION PROMEDIO: $60^{\circ} \mathrm{E}$ to vertical 
Comments/Comentarios: Dip estimated from geomorphic features and sheared outcrops (from general reconnaissance by Gabriel Paris (1966 to 1996).

SENSE OF MOVEMENT/SENTIDO DE MOVIMIENTO: Sinistral (left lateral) and reverse

Comments/Comentarios: East-side up.

GEOMORPHIC EXPRESSION/EXPRESION GEOMORFOLOGICA: The fault is an outstanding linear topographic feature. The large Bucaramanga alluvial fan shows sinistral offset as evidenced by its displacement from the feeder stream and the gradual southward increase in degree of dissection of the fan surface It has an average vertical offset of about $20 \mathrm{~m}$, athough most of the displacement is sinistral (left-lateral). Shutter ridges are very common, as are flexural ridges or L-shaped spurs, triangular facets, saddles, offset streams, sag ponds, fault scarps, strong breaks in slope. In addition, Quaternary alluvial deposits show displacement and tilting and the large Bucaramanga alluvial fan shows sinistral offset. Less common are displaced late Tertiary erosion surfaces, such as the "Paramo" de Berlin.

RECURRENCE INTERVAL/INTERVALO DE RECURRENCIA: 3-30 k.y.

Comments/Comentarios: Calculated on basis of slip rate values.

SLIP RATE/TASA DE MOVIMIENTO: $<0.2 \mathrm{~mm} / \mathrm{yr}$

Comments/Comentario: Slip rate of $0.01-0.1 \mathrm{~mm} / \mathrm{yr}$ calculated on basis of geomorphic offset features.

TIME OF MOST RECENT MOVEMENT/EDAD DEL ULTIMO MOVIMIENTO: Quaternary, <1.6 Ma

REFERENCES/REFERENCIAS

Campbell, C. J., 1965, The Santa Marta wrench fault of Colombia and its regional setting: Caribbean Geol. Conf., $4^{\text {th }}$, Port of Spain, Trinidad, and Tobago, Trans., p. 247-261.

Page, W.D., 1986, Seismic geology and seismicity of Northwestern Colombia: San Francisco, California, WoodwardClyde Consultants Report for ISA and Integral Ltda., Medellín, 200 p.

Paris, G., y Sarria, A., 1986, Proyecto Geofísico del Nordeste Colombiano-Neotectónica del Nororiente Colombiano: INGEOMINAS, Bogotá, Informe INGEOMINAS-ISA (Interconexión Eléctrica S.A.), 59 p.

Paris, G., y Romero, J., 1994, Fallas Activas en Colombia: INGEOMINAS, Boletin Geológico, v. 34, no. 2-3, p. 3-26 (Santafé de Bogotá).

Woodward-Clyde Consultants, 1982, Initial Seismic Hazards Evaluations, Fonce-Suarez Proyect, Colombia: San Francisco, California, Woodward-Clyde Consultants, unpublished report.

\section{CO-03, CAÑo TOMAS FAULT}

FAULT NUMBER/NUMERO DE LA FALLA: CO-03

FAULT NAME/NOMBRE DE LA FALLA: Caño Tomas

SYNOPSIS AND GEOLOGIC SETTING/SINOPSIS Y AMBIENTE GEOLOGICO: The fault is located about 50 $\mathrm{km}$ to the west of the town of Tibú, along the eastern base of the Cordillera Oriental. In the northern part, the fault places agglomerates and breccias of Jura-Triassic age against shales and sandstone of Cretaceous age. Farther south, it places Precambrian gneisses and migmatites against Cretaceous and Jura-Triassic rocks.

COMPILER, AFFILIATION, \& DATE OF COMPILATION/COMPILADOR, AFILIACION Y FECHA DE

COMPILACION: Gabriel Paris, Departamento de Geografía Universidad del Valle, January 2000.

TYPE OF STUDIES/TIPOS DE ESTUDIOS: Geologic reconnaissance by Page (1986).

GEOMETRY OF THE FAULT/GEOMETRIA DE LA FALLA:

LENGTH/LONGITUD: $81.6 \mathrm{~km}$ (82.3 km cumulative)

AVERAGE STRIKE/RUMBO PROMEDIO: $11.4^{\circ} \pm 8^{\circ}\left(\mathrm{N} 11.4^{\circ} \mathrm{E} \pm 8^{\circ}\right)$

AVERAGE DIP/INCLINACION PROMEDIO: Probably high to the west

Comments/Comentarios: Attitude estimated by Page (1986).

SENSE OF MOVEMENT/SENTIDO DE MOVIMIENTO: Reverse

Comments/Comentarios: Vertical component is west-side up.

GEOMORPHIC EXPRESSION/EXPRESION GEOMORFOLOGICA: The fault displaces the erosion

surface of the Cordillera Oriental about $1,000 \mathrm{~m}$ vertically according to a tographic survey that was

done along the fault. This indicates that the fault has been active. However no displacement of

Quaternary deposits were observed during aerial and land reconnaissance work by Page (1986).

RECURRENCE INTERVAL/INTERVALO DE RECURRENCIA: Unknown

SLIP RATE/TASA DE MOVIMIENTO: Unknown, probably $<0.2 \mathrm{~mm} / \mathrm{yr}$ 
TIME OF MOST RECENT MOVEMENT/EDAD DEL ULTIMO MOVIMIENTO: Quaternary?(<1.6 m.y.) REFERENCES/REFERENCIAS

Page, W.D., 1986, Seismic geology and seismicity of Northwestern Colombia: San Francisco, California, WoodwardClyde Consultants Report for ISA and Integral Ltda., Medellín, 200 p.

\section{CO-04, TARRA FAULT}

FAULT NUMBER/NUMERO DE LA FALLA: CO-04

FAULT NAME/NOMBRE DE LA FALLA: Tarra

SYNOPSIS AND GEOLOGIC SETTING/SINOPSIS Y AMBIENTE GEOLOGICO: The Tarra fault is located northwest of the city of Cucuta and Las Mercedes fault [CO-27]. The fault thrusts Precambrian and Paleozoic rocks over Cretaceous rocks.

COMPILER, AFFILIATION, \& DATE OF COMPILATION/COMPILADOR, AFILIACION Y FECHA DE COMPILACION: Gabriel Paris, Departamento de Geografía Universidad del Valle, January 2000.

TYPE OF STUDIES/TIPOS DE ESTUDIOS: Geologic reconnaissance by Page (1986).

GEOMETRY OF THE FAULT/GEOMETRIA DE LA FALLA:

LENGTH/LONGITUD: $26.8 \mathrm{~km}$ (27.0 km cumulative)

AVERAGE STRIKE/RUMBO PROMEDIO: $7.6^{\circ} \pm 8^{\circ}\left(\mathrm{N} 7.6^{\circ} \mathrm{E} \pm 8^{\circ}\right)$

AVERAGE DIP/INCLINACION PROMEDIO: Probably high to the west

Comments/Comentarios: Attitude estimated by Page (1986).

SENSE OF MOVEMENT/SENTIDO DE MOVIMIENTO: Reverse

Comments/Comentarios: Vertical component is west-side up.

GEOMORPHIC EXPRESSION/EXPRESION GEOMORFOLOGICA: Very pronounced morphologic

expression along the base of the mountain front through the western side of the Tarra valley. The strong topographic signature of the scarp suggests, according to Page (1986), that the fault is as active as other known Quaternary faults in the region.

RECURRENCE INTERVAL/INTERVALO DE RECURRENCIA: Unknown

SLIP RATE/TASA DE MOVIMIENTO: Unknown, probably $<0.2 \mathrm{~mm} / \mathrm{yr}$

TIME OF MOST RECENT MOVEMENT/EDAD DEL ULTIMO MOVIMIENTO: Quaternary (<1.6 m.y.)

REFERENCES/REFERENCIAS

Page, W.D., 1986, Seismic geology and seismicity of Northwestern Colombia: San Francisco, California, Woodward-

Clyde Consultants Report for ISA and Integral Ltda., Medellín, 200 p.

\section{CO-05, MONTERÍA FAULT}

FAULT NUMBER/NUMERO DE LA FALLA: CO-05

FAULT NAME/NOMBRE DE LA FALLA: Montería

SYNOPSIS AND GEOLOGIC SETTING/SINOPSIS Y AMBIENTE GEOLOGICO: The fault is located in the northwest corner of the country. It extends through the Sinú Valley and passes close to the town of Monteria. The fault places upper Tertiary rocks of the Sinu belt (to the west) against lower Tertiary rocks of the San Jacinto belt (to the east). To the north, the fault is covered by young alluvial deposits.

COMPILER, AFFILIATION, \& DATE OF COMPILATION/COMPILADOR, AFILIACION Y FECHA DE COMPILACION: Gabriel Paris, INGEOMINAS, Bogotá; November 1993. Reviewed January 1997 at CRQ and UNIQUINDIO, Armenia. Revised by Gabriel Paris, Estudios Geológico Mineros, Cali; June 1998.

TYPE OF STUDIES/TIPOS DE ESTUDIOS: Interpretation of aerial photographs and general geologic field studies.

GEOMETRY OF THE FAULT/GEOMETRIA DE LA FALLA:

LENGTH/LONGITUD: $202.2 \mathrm{~km}$ (202.6 km cumulative)

AVERAGE STRIKE/RUMBO PROMEDIO: $10^{\circ} \pm 4^{\circ}\left(\mathrm{N} 10.4^{\circ} \mathrm{E} \pm 4^{\circ}\right)$

AVERAGE DIP/INCLINACION PROMEDIO: High angle to the east

SENSE OF MOVEMENT/SENTIDO DE MOVIMIENTO: Reverse with east-side up.

GEOMORPHIC EXPRESSION/EXPRESION GEOMORFOLOGICA: Strong linear topographic features and offset Quaternary alluvial deposits.

RECURRENCE INTERVAL/INTERVALO DE RECURRENCIA: Unknown 
SLIP RATE/TASA DE MOVIMIENTO: $<0.2 \mathrm{~mm} / \mathrm{yr}$

TIME OF MOST RECENT MOVEMENT/EDAD DEL ULTIMO MOVIMIENTO: Quaternary, <1.6 Ma REFERENCES/REFERENCIAS

Duque-Caro, H., 1980, Geotectónica y Evolución de la región Noroccidental de Colombia: Boletin Geológico INGEOMINAS, Bogotá, v. 23, no.3, p. 4-37.

Page, W.D., 1986, Seismic geology and seismicity of Northwestern Colombia: San Francisco, California, WoodwardClyde Consultants Report for ISA and Integral Ltda., Medellín, 200 p.

Woodward-Clyde Consultants, 1982, Preliminary Seismic Hazard Study, Alto Sinú Proyect Colombia: San Francisco, California, Woodward-Clyde Consultants unpublished report for ISA and Gomez Cajiao y Asociados, Cia Ltda., Bogotá, $105 \mathrm{p}$.

\section{CO-06, TUCURA FAULT}

FAULT NUMBER/NUMERO DE LA FALLA: CO-06

FAULT NAME/NOMBRE DE LA FALLA: Tucura

SYNOPSIS AND GEOLOGIC SETTING/SINOPSIS Y AMBIENTE GEOLOGICO: The Tucura fault is located in the northern part of the Cordillera Central of Colombia, west of the Romeral fault system [CO-15]. It extends from the Rio Paderisco in the south to the Sinu Valley in the north, where it crosses the Serranía de Abibe. The fault crosscuts middle and upper Tertiary folded marine sedimentary rocks and Quaternary alluvial deposits.

COMPILER, AFFILIATION, \& DATE OF COMPILATION/COMPILADOR, AFILIACION Y FECHA DE COMPILACION: Gabriel Paris, INGEOMINAS, Bogotá; November 1993. Reviewed January 1997 at CRQ and UNIQUINDIO, Armenia. Revised by Gabriel Paris, Estudios Geológico Mineros, Cali; June 1998.

TYPE OF STUDIES/TIPOS DE ESTUDIOS: Interpretation of aerial photographs, reconnaissance field studies and detailed local geologic field work.

GEOMETRY OF THE FAULT/GEOMETRIA DE LA FALLA:

LENGTH/LONGITUD: $74.3 \mathrm{~km}$ (74.9 km cumulative)

AVERAGE STRIKE/RUMBO PROMEDIO: $-4.0^{\circ} \pm 8^{\circ}\left(\mathrm{N} 4.0^{\circ} \mathrm{W} \pm 8^{\circ}\right)$

Comments/Comentarios: Page (1986).

AVERAGE DIP/INCLINACION PROMEDIO: $70-80^{\circ} \mathrm{E}$

SENSE OF MOVEMENT/SENTIDO DE MOVIMIENTO: Reverse

Comments/Comentarios: East-side up. Appears to have slight sinistral (left-lateral) movement.

GEOMORPHIC EXPRESSION/EXPRESION GEOMORFOLOGICA: Fault controls drainage, forms linear ridges, topographic lineaments, and fault scarps about $4 \mathrm{~m}$ high on Quaternary terraces south of the town of Dabeiba, Antioquia. There are strong linear features on the right margin of the Esmeralda and Sinú rivers; these include fault saddles and slight slope changes in alluvial terraces. Tertiary rock units are thrust over Quaternary deposits and striae are found on the shear planes.

RECURRENCE INTERVAL/INTERVALO DE RECURRENCIA: Unknown

SLIP RATE/TASA DE MOVIMIENTO: 0.2-1 mm/yr

Comments/Comentarios: Calculated rate of $0.2 \mathrm{~mm} / \mathrm{yr}$ is from inferred age and offset of topographic features.

TIME OF MOST RECENT MOVEMENT/EDAD DEL ULTIMO MOVIMIENTO: Holocene/post glacial, $<15$ ka (?) Comments/Comentarios: Movement probably $<15 \mathrm{ka}$ on basis of slip rate, geomorphic expression, and presence of fault scarps. Possibly historic on basis of three shallow earthquakes that occurred in the vicinity of this fault.

NAME OF EARTHQUAKE/NOMBRE DEL TERREMOTO: Sinu

Comments/Comentarios: Three shallow earthquakes have probably occurred on this fault since 1952.

DATES/FECHAS: February 12, 1952; December 3, 1970; and August 31, 1977.

MAGNITUDE OR INTENSITY/MAGNITUD O INTENSIDAD: M 6.7 (1952), M 5.7 (1970), and M 5.7 (1977)

LENGTH OF SURFACE RUPTURE/LONGITUD DE RUPTURA: Unknown

REFERENCES/REFERENCIAS

Page, W.D., 1986, Seismic geology and seismicity of Northwestern Colombia: San Francisco, California, WoodwardClyde Consultants Report for ISA and Integral Ltda., Medellín, $200 \mathrm{p}$.

Paris, G., y Romero, J., 1994, Fallas Activas en Colombia: INGEOMINAS, Boletin Geológico, v. 34, no. 2-3, p. 3-26 (Santafé de Bogotá). 
Woodward-Clyde Consultants, 1982, Preliminary Seismic Hazard Study, Alto Sinú Proyect Colombia: San Francisco, California, Woodward-Clyde Consultants unpublished report for ISA and Gomez Cajiao y Asociados, Cia Ltda., Bogotá, 105 p.

\section{CO-07, MUTATÁ FAULT}

FAULT NUMBER/NUMERO DE LA FALLA: CO-07

FAULT NAME/NOMBRE DE LA FALLA: Mutatá

SYNOPSIS AND GEOLOGIC SETTING/SINOPSIS Y AMBIENTE GEOLOGICO: The Mutatá fault is located in northwestern Colombia, between the Rio Penderísco and the Caribbean Sea. To the south, near the town of Mutatá, the Mutatá fault approaches the Murri fault [CO-11] and the two fault zones practically merge. In this area, the Mutatá fault places Cretaceous intrusive rocks and greenstones (to the east) in contact with sedimentary Tertiary rocks (to the west). Farther north, the fault cuts Tertiary and Quaternary deposits, with uplift of the eastern block. The Mutatá fault is located near the junction of the Nazca, Caribbean, and South American plates.

COMPILER, AFFILIATION, \& DATE OF COMPILATION/COMPILADOR, AFILIACION Y FECHA DE COMPILACION: Gabriel Paris, Estudios Geológico Mineros, Cali; June 1998.

TYPE OF STUDIES/TIPOS DE ESTUDIOS: Interpretation of satellite images, and morphotectonic field studies.

GEOMETRY OF THE FAULT/GEOMETRIA DE LA FALLA:

LENGTH/LONGITUD: $44.7 \mathrm{~km}$ (45.3 km cumulative)

AVERAGE STRIKE/RUMBO PROMEDIO: $-33.6^{\circ} \pm 11^{\circ}\left(\mathrm{N} 33.6^{\circ} \mathrm{W} \pm 11^{\circ}\right)$

AVERAGE DIP/INCLINACION PROMEDIO: Probably medium to high angle to the east. SENSE OF MOVEMENT/SENTIDO DE MOVIMIENTO: Sinistral (left-lateral) reverse

GEOMORPHIC EXPRESSION/EXPRESION GEOMORFOLOGICA: There is an elongate, tectonically depressed zone between the Mutatá and Murri [CO-11] faults. The Mutatá fault has prominent topographic expression near the town of Mutata, as seen on SIR-A satellite images. To the north of Rio Sucio, the Mutatá fault shows discontinuous linear valleys, notches, and trenches (grabens). There are aligned hills and slope changes close to the Cordillera Occidental. Fault scarps, sag ponds, and aligned valleys are very common tectonic features along most of the fault's trace.

RECURRENCE INTERVAL/INTERVALO DE RECURRENCIA: Unknown

SLIP RATE/TASA DE MOVIMIENTO: 0.2-1 mm/yr

Comments/Comentarios: Low to medium rate is based on displacement of geomorphic features of known age.

TIME OF MOST RECENT MOVEMENT/EDAD DEL ULTIMO MOVIMIENTO: Holocene/post glacial, $<15 \mathrm{ka}$ Comments/Comentarios: Fault offsets mudflows that are 10-50 ka (latest Pleistocene age). However, the most recent movement is perhaps $<1.5 \mathrm{ka}$ or possibly historic if the September 7, 1882 intensity X Turbo earthquake was associated with the fault movement (Page, 1986).

REFERENCES/REFERENCIAS

Page, W.D., 1986, Seismic geology and seismicity of Northwestern Colombia: San Francisco, California, WoodwardClyde Consultants Report for ISA and Integral Ltda., Medellín, 200 p.

Paris, G., y Romero, J., 1994, Fallas Activas en Colombia: INGEOMINAS, Boletin Geológico, v. 34, no. 2-3, p. 3-26 (Santafé de Bogotá).

Ramirez, J.E., 1975, "Historia de los Terremotos de Colombia”, Seg. E.: Instituto Geográfico Agustín Codazzi, 250 p. (Bogotá).

\section{CO-08, MURINDÓ FAULT}

FAULT NUMBER/NUMERO DE LA FALLA: CO-08

FAULT NAME/NOMBRE DE LA FALLA: Murindó

SYNOPSIS AND GEOLOGIC SETTING/SINOPSIS Y AMBIENTE GEOLOGICO: The fault extends along the western slope of the Cordillera Occidental of Colombia, from the Río Arquia in the south to the Rio Sucio and the basin of the Rio Atrato in the north. The Murindo fault places Cretaceous volcanic (basic) rocks against Tertiary turbidites, and crosscuts Tertiary quartz-diorite and granodiorite. 
COMPILER, AFFILIATION, \& DATE OF COMPILATION/COMPILADOR, AFILIACION Y FECHA DE COMPILACION: Gabriel Paris, INGEOMINAS, Bogotá; November 1993. Reviewed January 1997 at CRQ and UNIQUINDIO, Armenia. Revised by Gabriel Paris, Estudios Geológico Mineros, Cali; June 1998.

TYPE OF STUDIES/TIPOS DE ESTUDIOS: Interpretation of aerial photographs and reconnaissance geologic field studies.

GEOMETRY OF THE FAULT/GEOMETRIA DE LA FALLA:

LENGTH/LONGITUD: $60.6 \mathrm{~km}(60.8 \mathrm{~km}$ cumulative)

AVERAGE STRIKE/RUMBO PROMEDIO: $-12.6^{\circ} \pm 6^{\circ}\left(\mathrm{N} 12.6^{\circ} \mathrm{W} \pm 6^{\circ}\right)$

AVERAGE DIP/INCLINACION PROMEDIO: High, probably to the east

SENSE OF MOVEMENT/SENTIDO DE MOVIMIENTO: Sinistral (left-lateral)

Comments/Comentarios: West-side up.

GEOMORPHIC EXPRESSION/EXPRESION GEOMORFOLOGICA: In the southernmost part, the fault shows evidence of tectonic control of streams. It also forms aligned saddles that face toward the mountain front.

RECURRENCE INTERVAL/INTERVALO DE RECURRENCIA: Unknown

SLIP RATE/TASA DE MOVIMIENTO: 0.2-1 mm/yr

Comments/Comentarios: Low to medium rate estimate based on the preservation of geomorphological and neotectonic features. Rate of activity somewhat uncertain in the forested area.

TIME OF MOST RECENT MOVEMENT/EDAD DEL ULTIMO MOVIMIENTO: Historic (1992)

Comments/Comentarios: See information below.

NAME OF EARTHQUAKE/NOMBRE DEL TERREMOTO: Murindó

DATE/FECHA: October 18, 1992; Time 16:12:01

MAGNITUDE OR INTENSITY/MAGNITUD O INTENSIDAD: M 7.3

Comments/Comentarios: It is belived that this earthquake and many others that occurred since 1883 are associated with activity along the Murindo fault (Martinez and others, 1993). A M 6.7 foreshock took place on October 17, 1992.

LENGTH OF SURFACE RUPTURE/LONGITUD DE RUPTURA: No surface rupture is known to be associated with the earthquake

REFERENCES/REFERENCIAS

Page, W.D., 1986, Seismic geology and seismicity of Northwestern Colombia: San Francisco, California, WoodwardClyde Consultants Report for ISA and Integral Ltda., Medellín, 200 p.

Paris, G., y Romero, J., 1994, Fallas Activas en Colombia: INGEOMINAS, Boletin Geológico, v. 34, no. 2-3, p. 3-26 (Santafé de Bogotá).

Martinez, J., M., Parra, E., Paris, G., Forero, C., Bustamante, M., Cardona, O.D., Jaramillo, J.D., 1993, "Los Sismos del Atrato Medio 17 y 18 de Octubre de 1982, Noroccidente de Colombia": INGEOMINAS, Bogotá, 45 p.

\section{CO-09, UNGUIA FAULT}

FAULT NUMBER/NUMERO DE LA FALLA: CO-09

FAULT NAME/NOMBRE DE LA FALLA: Unguía

SYNOPSIS AND GEOLOGIC SETTING/SINOPSIS Y AMBIENTE GEOLOGICO: The fault is located in the Darien area of northwestern Colombia. It has an irregular arcuate strike, but it has a general north tendency. In Colombia, it has been mapped as far north as the town of Acandí: farther north, it enters the Caribbean Sea, where it parallels the coast of Panama (Page, 1986). The Unguía fault is likely a southern continuation of the eastern section of the Northern Panama deformed belt [PA-12c] where it comes onland in northwestern Colombia.

COMPILER, AFFILIATION, \& DATE OF COMPILATION/COMPILADOR, AFILIACION Y FECHA DE COMPILACION: Gabriel Paris, Estudios Geológico Mineros, Cali; June 1998 and December 1999.

TYPE OF STUDIES/TIPOS DE ESTUDIOS: Geologic reconnaissance by Page (1986).

GEOMETRY OF THE FAULT/GEOMETRIA DE LA FALLA:

LENGTH/LONGITUD: $139.9 \mathrm{~km}$ (155.0 km cumulative)

AVERAGE STRIKE/RUMBO PROMEDIO: $-3.7^{\circ} \pm 30^{\circ}\left(\mathrm{N} 3.7^{\circ} \mathrm{W} \pm 30^{\circ}\right)$

AVERAGE DIP/INCLINACION PROMEDIO: Low to moderate to the west

Comments/Comentarios: The attitude of the fault is inferred to be low to moderate as determined by Page (1986) from solutions of focal mechanisms near the fault. 
SENSE OF MOVEMENT/SENTIDO DE MOVIMIENTO: Reverse, dextral (right-lateral)

Comments/Comentarios: This arcuate fault has a reverse (or thrust) and dextral sense of movement according to Page (1986).

GEOMORPHIC EXPRESSION/EXPRESION GEOMORFOLOGICA: The fault is prominent on satellite images and topographic maps. The irregular boundary between the Serrania de Darien and the Valle del Atrato suggests that the fault is a reverse or thrust that dips northwest (Page, 1986). Along its southern extent, the fault forms a scarp that faces east and is a few tens of meters high. The fault separates alluvium of the Atrato and Tuira Rivers from Tertiary strata. To the northwest, where the fault cuts the base of the Serrania del Darien, the scarp and the contact between the Atrato alluvium and Tertiary rocks are sinuous. To the north of Unguia, the fault strikes north through the Bajo Atrato, probably extending either into the Golfo de Uraba or to the northwest into the Caribbean Sea.

RECURRENCE INTERVAL/INTERVALO DE RECURRENCIA: Unknown

SLIP RATE/TASA DE MOVIMIENTO: Unknown, probably 0.2-1 mm/yr

TIME OF MOST RECENT MOVEMENT/EDAD DEL ULTIMO MOVIMIENTO: Probably Quaternary, $<1.6 \mathrm{Ma}$

Comments/Comentarios: Many shallow earthquakes occur along the Unguía fault (Page, 1986) indicating that the fault probably is active. Further studies are needed in order to refine its time of most recent movement.

REFERENCES/REFERENCIAS

Page, W.D., 1986, Seismic geology and seismicity of Northwestern Colombia: San Francisco, California, WoodwardClyde Consultants Report for ISA and Integral Ltda., Medellín, 200 p.

\section{CO-10, BAHIA SOLANO FAULT}

FAULT NUMBER/NUMERO DE LA FALLA: CO-10

FAULT NAME/NOMBRE DE LA FALLA: Bahia Solano

SYNOPSIS AND GEOLOGIC SETTING/SINOPSIS Y AMBIENTE GEOLOGICO: The Bahia Solano fault extends along the Pacific Coast of Colombia. It bounds a structural valley between the Solano Bay and Utria Bay, and displaces Cenozoic sedimentary rocks. THE BAYS MUST BE PLACED ON THE MAP

COMPILER, AFFILIATION, \& DATE OF COMPILATION/COMPILADOR, AFILIACION Y FECHA DE COMPILACION: Gabriel Paris, INGEOMINAS, Bogotá; November 1993. Reviewed January 1997 at CRQ and UNIQUINDIO, Armenia. Revised by Gabriel Paris, Estudios Geológico Mineros, Cali; June 1998.

TYPE OF STUDIES/TIPOS DE ESTUDIOS: Detailed geologic and neotectonic field studies.

GEOMETRY OF THE FAULT/GEOMETRIA DE LA FALLA:

LENGTH/LONGITUD: $290.6 \mathrm{~km}$ (296.5 km cumulative)

AVERAGE STRIKE/RUMBO PROMEDIO: $-3.7^{\circ} \pm 13^{\circ}\left(\mathrm{N} 3.7^{\circ} \mathrm{W} \pm 13^{\circ}\right)$

AVERAGE DIP/INCLINACION PROMEDIO: Unknown, to the west

SENSE OF MOVEMENT/SENTIDO DE MOVIMIENTO: Reverse

Comments/Comentarios: Vertical component is west-side up.

GEOMORPHIC EXPRESSION/EXPRESION GEOMORFOLOGICA: Forms a well developed and continuous fault line (scarp) (Page 1986).

RECURRENCE INTERVAL/INTERVALO DE RECURRENCIA: Unknown

SLIP RATE/TASA DE MOVIMIENTO: 0.2-1 mm/yr

Comments/Comentarios: William Page, written comunication to Michael Machette (July 9, 1999).

TIME OF MOST RECENT MOVEMENT/EDAD DEL ULTIMO MOVIMIENTO: Historic (1970)

NAME OF EARTHQUAKE/NOMBRE DEL TERREMOTO: 1970 Bahia Solano (Puerto Mutis)

DATE/FECHA: 09/26/70

MAGNITUDE OR INTENSITY/MAGNITUD O INTENSIDAD: M 6.5

LENGTH OF SURFACE RUPTURE/LONGITUD DE RUPTURA: Small changes in landscape topography. REFERENCES/REFERENCIAS

Page, W.D., 1986, Seismic geology and seismicity of Northwestern Colombia: San Francisco, California, WoodwardClyde Consultants Report for ISA and Integral Ltda., Medellín, 200 p.

Ramirez, J.E., 1975, "Historia de los Terremotos de Colombia”, Seg. E.: Instituto Geográfico Agustín Codazzi, 250 p. (Bogotá). 


\section{CO-11, MURRI FAULT}

FAULT NUMBER/NUMERO DE LA FALLA: CO-11

FAULT NAME/NOMBRE DE LA FALLA: Murri

SYNOPSIS AND GEOLOGIC SETTING/SINOPSIS Y AMBIENTE GEOLOGICO: Located in the western limb of the Cordillera Occidental of Colombia. The fault puts Cretaceous mafic igneous rock to the east in contact withTertiary marine sedimentary rocks to the west.

COMPILER, AFFILIATION, \& DATE OF COMPILATION/COMPILADOR, AFILIACION Y FECHA DE COMPILACION: Gabriel Paris, INGEOMINAS, Bogotá; November 1993. Reviewed January 1997 at CRQ and UNIQUINDIO, Armenia. Revised by Gabriel Paris, Estudios Geológico Mineros, Cali; June 1998.

TYPE OF STUDIES/TIPOS DE ESTUDIOS: Interpretation of aerial photographs, general and detailed geologic field studies.

GEOMETRY OF THE FAULT/GEOMETRIA DE LA FALLA:

LENGTH/LONGITUD: $87.1 \mathrm{~km}$ (87.3 km cumulative)

AVERAGE STRIKE/RUMBO PROMEDIO: $1.4^{\circ} \pm 5^{\circ}\left(\mathrm{N} 1.4^{\circ} \mathrm{E} \pm 5^{\circ}\right)$

AVERAGE DIP/INCLINACION PROMEDIO: Unknown

SENSE OF MOVEMENT/SENTIDO DE MOVIMIENTO: Reverse sinistral (left lateral)

Comments/Comentarios: Reverse component is east-side up.

GEOMORPHIC EXPRESSION/EXPRESION GEOMORFOLOGICA: The fault cuts mud flows dated at about 10,000 to 15,000 years (Page, 1986). Causes strong lineaments and offsets terraces and alluvial

deposits. Forms well developed scarps of about 20-m high on late Quaternary alluvial deposits.

RECURRENCE INTERVAL/INTERVALO DE RECURRENCIA: Unknown

SLIP RATE/TASA DE MOVIMIENTO: 0.2-1 mm/yr

Comments/Comentarios: Low to medium rate estimate based strictly on vertical (minor) component: $20 \mathrm{~m}$ high scarps on late Quaternary alluvial deposits (i.e., $20 \mathrm{~m}$ vertical slip in 100,000 yrs) yields minimum 0.2 $\mathrm{mm} / \mathrm{yr})$.

TIME OF MOST RECENT MOVEMENT/EDAD DEL ULTIMO MOVIMIENTO: Quaternary, $<1.6 \mathrm{Ma}$

REFERENCES/REFERENCIAS

Page, W.D., 1986, Seismic geology and seismicity of Northwestern Colombia: San Francisco, California, WoodwardClyde Consultants Report for ISA and Integral Ltda., Medellín, 200 p.

Paris, G., y Romero, J., 1994, Fallas Activas en Colombia: INGEOMINAS, Boletin Geológico, v. 34, no. 2-3, p. 3-26 (Santafé de Bogotá).

\section{CO-12, CAÑASGORDAS FAULT}

FAULT NUMBER/NUMERO DE LA FALLA: CO-12

FAULT NAME/NOMBRE DE LA FALLA: Cañasgordas

SYNOPSIS AND GEOLOGIC SETTING/SINOPSIS Y AMBIENTE GEOLOGICO: The Cañasgordas fault is located to the northwest of the city of Medellin. The fault traverses most of the Cordillera Occidental between the towns of Dabeiba and Giraldo in the department (state) of Antioquia. The Cañasgordas fault probably joins the Mutatá fault [CO-07]. The fault displaces Cretaceous sedimentary and volcanic rocks, Tertiary sedimentary rocks, and Quaternary mudflows.

COMPILER, AFFILIATION, \& DATE OF COMPILATION/COMPILADOR, AFILIACION Y FECHA DE COMPILACION: Gabriel Paris, Estudios Geológico Mineros, Cali; February 1998

TYPE OF STUDIES/TIPOS DE ESTUDIOS: Reconnaissance neotectonic and morphotectonic field studies. GEOMETRY OF THE FAULT/GEOMETRIA DE LA FALLA:

LENGTH/LONGITUD: $54.8 \mathrm{~km}$ (54.9 km cumulative)

AVERAGE STRIKE/RUMBO PROMEDIO: $-44.8^{\circ} \pm 4^{\circ}\left(\mathrm{N} 44.8^{\circ} \mathrm{W} \pm 4^{\circ}\right)$

AVERAGE DIP/INCLINACION PROMEDIO: High to the southwest

SENSE OF MOVEMENT/SENTIDO DE MOVIMIENTO: Reverse sinistral (left-lateral)

GEOMORPHIC EXPRESSION/EXPRESION GEOMORFOLOGICA: Fault forms strong linear features on satellite images and aerial photographs and controls the course of the Rio Sucio, which has a prominent, linear V-shaped valley. Fault scarps are formed on Quaternary mudflows.

RECURRENCE INTERVAL/INTERVALO DE RECURRENCIA: Unknown 
SLIP RATE/TASA DE MOVIMIENTO: $<0.2 \mathrm{~mm} / \mathrm{yr}$

Comments/Comentarios: Slip rate of 0.01-0.1 mm/yr deduced from offset of mudflows (see Page, 1986).

TIME OF MOST RECENT MOVEMENT/EDAD DEL ULTIMO MOVIMIENTO: Quaternary, <1.6 Ma

Comments/Comentarios: Probably late Quaternary (<130 k.y.) based on the presence of fault scarps on mudflows.

REFERENCES/REFERENCIAS

Page, W.D., 1986, Seismic geology and seismicity of Northwestern Colombia: San Francisco, California, WoodwardClyde Consultants Report for ISA and Integral Ltda., Medellín, $200 \mathrm{p}$.

Paris, G., y Romero, J., 1994, Fallas Activas en Colombia: INGEOMINAS, Boletin Geológico, v. 34, no. 2-3, p. 3-26 (Santafé de Bogotá).

Woodward-Clyde Consultants, 1980, Phase I, Preliminary Seismic Hazard Study Ituango Proyect, Colombia: San Francisco, California, Woodward-Clyde Consultants unpublished report for Integral Ltda., and ISA, Medellín 97 p.

\section{CO-13, ABRIAQUI FAULT}

FAULT NUMBER/NUMERO DE LA FALLA: CO-13

FAULT NAME/NOMBRE DE LA FALLA: Abriaqui

SYNOPSIS AND GEOLOGIC SETTING/SINOPSIS Y AMBIENTE GEOLOGICO: The Abriaqui fault parallels the Cañasgordas fault [CO-12] to the south, cutting Cretaceous oceanic volcanic rock as well as Tertiary and Cretaceous sedimentary rock.

COMPILER, AFFILIATION, \& DATE OF COMPILATION/COMPILADOR, AFILIACION Y FECHA DE COMPILACION: Gabriel Paris, Estudios Geológico Mineros, Cali; June 1998.

TYPE OF STUDIES/TIPOS DE ESTUDIOS: General geomorphologic and neotectonic studies.

GEOMETRY OF THE FAULT/GEOMETRIA DE LA FALLA:

LENGTH/LONGITUD: $33.8 \mathrm{~km}$ (33.8 km cumulative)

AVERAGE STRIKE/RUMBO PROMEDIO: $-49.0^{\circ} \pm 2^{\circ}\left(\mathrm{N} 49.0^{\circ} \mathrm{W} \pm 2^{\circ}\right)$

AVERAGE DIP/INCLINACION PROMEDIO: High to the northeast

SENSE OF MOVEMENT/SENTIDO DE MOVIMIENTO: Reverse, sinistral (left-lateral)

GEOMORPHIC EXPRESSION/EXPRESION GEOMORFOLOGICA: Well defined fault trace with scarps, saddles, and deflected streams.

RECURRENCE INTERVAL/INTERVALO DE RECURRENCIA: Unknown

SLIP RATE/TASA DE MOVIMIENTO: 0.2-1.0 mm/yr

Comments/Comentarios: Low to moderate rate estimated from displaced geomorphic features.

TIME OF MOST RECENT MOVEMENT/EDAD DEL ULTIMO MOVIMIENTO: Quaternary <1.6 Ma

REFERENCES/REFERENCIAS

Page, W.D.,1983, Quaternary faulting in Northwestern Colombia [abs.]: Transactions of 10th Caribbean Geological Conference, Cartagena, Colombia, p. 254.

Page, W.D., 1986, Seismic geology and seismicity of Northwestern Colombia: San Francisco, California, WoodwardClyde Consultants Report for ISA and Integral Ltda., Medellín, 200 p.

\section{CO-14, URRAO FAULT}

FAULT NUMBER/NUMERO DE LA FALLA: CO-14

FAULT NAME/NOMBRE DE LA FALLA: Urrao

SYNOPSIS AND GEOLOGIC SETTING/SINOPSIS Y AMBIENTE GEOLOGICO: This set of two parallel faults extend along the axis of the Cordillera Occidental close to the valleys of the Anacosca and Penderisco Rivers, and the Frontino "Paramo" (plateau). Located to the west of the city of Medellin, the faults mainly displace Tertiary sedimentary rocks.

COMPILER, AFFILIATION, \& DATE OF COMPILATION/COMPILADOR, AFILIACION Y FECHA DE COMPILACION: Gabriel Paris, Estudios Geológico Mineros, Cali; June 1998.

TYPE OF STUDIES/TIPOS DE ESTUDIOS: Geologic reconnaissance by Page (1986).

GEOMETRY OF THE FAULT/GEOMETRIA DE LA FALLA:

LENGTH/LONGITUD: $30.5 \mathrm{~km}$ (30.5 km cumulative)

AVERAGE STRIKE/RUMBO PROMEDIO: $3.6^{\circ} \pm 1^{\circ}\left(\mathrm{N} 3.6^{\circ} \mathrm{E} \pm 1^{\circ}\right)$

AVERAGE DIP/INCLINACION PROMEDIO: Probably vertical 
SENSE OF MOVEMENT/SENTIDO DE MOVIMIENTO: Sinistral (left-lateral)

Comments/Comentarios: The west branch of the fault has mainly normal slip as observed by Hans

Diederix (personal field observation) from offset alluvial terraces.

GEOMORPHIC EXPRESSION/EXPRESION GEOMORFOLOGICA: Forms spectacular fault scarps on terraces. These scarps are 10-km long and as much as $50-\mathrm{m}$ high. Most of the fault trace has a moderate alignment of topographic features, such as linear streams and offset spurs. Quaternary alluvial sediments of the Panderisco River are offset an unknown amount. The west branch of the fault has mainly normal with vertical offset of alluvial terraces of about $15 \mathrm{~m}$ according to Hans Diederix (personal observation).

RECURRENCE INTERVAL/INTERVALO DE RECURRENCIA: Unknown

SLIP RATE/TASA DE MOVIMIENTO: 0.2-1 mm/yr

Comments/Comentarios: Moderate rate of 0.1-1.0 mm/yr calculated from displaced Quaternary sediment as discussed by Page (1986).

TIME OF MOST RECENT MOVEMENT/EDAD DEL ULTIMO MOVIMIENTO: Quaternary $<1.6 \mathrm{Ma}$

REFERENCES/REFERENCIAS

Page, W.D., 1986, Seismic geology and seismicity of Northwestern Colombia: San Francisco, California, WoodwardClyde Consultants Report for ISA and Integral Ltda., Medellín, 200 p.

Woodward-Clyde Consultants, 1981, Initial evaluation of fault activity, Penderisco Hidroelectric Proyect: Letter report to E. Bacci, Sedic Ltda., Medellín, 3 p.

\section{CO-15, ROMERAL FAULT SYSTEM}

\section{FAULT NUMBER/NUMERO DE LA FALLA: CO-15}

FAULT NAME/NOMBRE DE LA FALLA: Romeral (or Romeral fault system) Comments/Comentarios: The Romeral (or Romeral fault system) is one of the most active and continuous fault systems in Colombia. In the literature, several names have been applied to the fault system as it traverses the length of the country. The oldest name is the Guayaquil-Dolores megashear, which involves a whole set of parallel fractures in Western Colombia. The number of faults that comprise the width of the system ranges between three and five, depending upon location in the country. Near latitude $7^{\circ} \mathrm{N}$, the fault system includes the Peque, Heliconia, Sabanalarga, and Cauca Occidental faults, mainly in the department (state) of Antioquia. Farther south, between about latitudes $1^{\circ}$ and $5^{\circ} \mathrm{N}$, the faults are known from north to south as the Pijao-Silvia, Quebradagrande, Potrerillos, Guabas-Pradera, Cauca-Almaguer, Rosas- Julumito, Popayán, Paispamba, El Rosal, and Buesaco.

SYNOPSIS AND GEOLOGIC SETTING/SINOPSIS Y AMBIENTE GEOLOGICO: This almost 700-km-long fault system is comprised of three or four parallel regional fractures (faults) that form the transition zone between oceanic rocks to the west and continental rocks to the east. The geology of the western domain consists of an ophiolitic belt with oceanic gabroic, basaltic and sedimentary rocks of Cretaceous age. The eastern domain consists primarily of continentalized metamorphic schistose, oceanic, and continental rocks, mainly of Paleozoic age. The Romeral fault system forms a 20- to $40-\mathrm{km}$-wide deformed belt that is parallel to the western slope of the Cordillera Central of Colombia; it extends from the Guayaquil Gulf in Ecuador in the south through Colombia to the Caribbean Sea in the north. At least one ancient subduction zone is believed to underlay some parta of the zone. Although this is the most studied fault system in Colombia, little is still known about its paleoseismic characteristics (most recent faulting, slip rates, and recurrence intervals).

COMPILER, AFFILIATION, \& DATE OF COMPILATION/COMPILADOR, AFILIACION Y FECHA DE COMPILACION: Gabriel Paris, INGEOMINAS, Bogotá; November 1993. Reviewed January 1997 at CRQ and UNIQUINDIO, Armenia. Revised by Gabriel Paris, Estudios Geológico Mineros, Cali; June 1998.

TYPE OF STUDIES/TIPOS DE ESTUDIOS: Several regional and detailed field studies including geophysics, interpretation of aerial photographs and satellite images, neotectonics, microtectonics, morphotectonics, and trench investigations.

GEOMETRY OF THE FAULT/GEOMETRIA DE LA FALLA:

LENGTH/LONGITUD: $697.4 \mathrm{~km}$ (1787.9 km cumulative)

AVERAGE STRIKE/RUMBO PROMEDIO: $17.6^{\circ} \pm 16^{\circ}\left(\mathrm{N} 17.6^{\circ} \mathrm{E} \pm 16^{\circ}\right)$

Comments/Comentarios: NNE from the city of Pasto to around Pereira in the middle part of the country.

Strikes in general north direction from Pereira to the Caribbean Sea (in the north). 


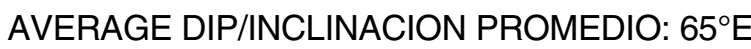

SENSE OF MOVEMENT/SENTIDO DE MOVIMIENTO: Reverse sinistral (left lateral) in the northern part of the country, conspicuous to about latitude $5^{\circ} \mathrm{N}$; from there south to Ecuador it is mainly reverse-dextral (right lateral).

GEOMORPHIC EXPRESSION/EXPRESION GEOMORFOLOGICA: Forms prominent fault line and well developed fault scarps as much as $400 \mathrm{~m}$ high on Pleistocene deposits, and eroded scarps on older Cretaceous to Paleozoic rocks. Forms outstanding break in slope above the easternmost parallel set of faults. The upper part of the easternmost major scarps forms the topographic divide of the Cordillera Central de Colombia. Regional neotectonic features (in different places) include linear valleys, offset drainages, aligned creeks, triangular facets, saddles, and L-shaped spurs and linear ridges. The fault offsets Quaternary volcanic rock, alluvium and colluvium.

NUMBER OF SECTIONS/NOMBRE DE LA SECCIONES: 6 Comments/Comentarios: Although the fault system contains tens of individual faults, only seven faults are described below as sections of the Romeral fault system. Other fault traces of the system (see map plate), which constitute the majority of its nearly $1800 \mathrm{~km}$ of surface ruptures, are not described separately because no detailed neotectonic information is available.

REFERENCES/REFERENCIAS

Duque-Caro, H., 1980, Geotectónica y Evolución de la región Noroccidental de Colombia: Boletin Geológico INGEOMINAS, Bogotá, v. 23, no.3, p. 4-37.

Hutchings, L., Torcotte, T., McBride, J., Rocha, H., 1981, Microseismicity along and near the Dolores shear zone in Antioquia, Colombia: CIAF (Centro Interamericano de Fotointerpretación), Memorias del I Seminario sobre el Cuaternario de Colombia, Agosto 25-29 de 1980, p. 243-285 (Bogotá).

Page, W. D., 1986, Seismic geology and seismicity of Northwestern Colombia. Report for ISA and Integral Ltda. from WCC, Medellín, $200 \mathrm{p}$.

Paris, G., 1993, Investigación Neotectónica en los Sistemas de Falla de Romeral y Cali-Patía, Departamento del Valle , Colombia: VI Seminario Internacional sobre Ingeniería Sísmica, Universidad de los Andes, Santafé de Bogotá, p. 1-29.

Paris, G., y Souret, B., 1993, Microzonificación Sismogeotécnica de Popayán. Subproyecto Neotectónica. Proyecto Colombo-Europeo No. CCE NA 84/03: Comunidad Economica Europea-INGEOMINAS-BRGM-ADK-KS, Publicaciones Especiales de INGEOMINAS, no. 2, p. 28-49, Bogotá.

Paris, G., y Romero, J., 1994, Fallas Activas en Colombia: INGEOMINAS, Boletin Geológico, v. 34, no. 2-3, p. 3-26 (Santafé de Bogotá).

Ramirez, J.E., 1975, "Historia de los Terremotos de Colombia", Seg. E.: Instituto Geográfico Agustín Codazzi, 250 p. (Bogotá).

Woodward-Clyde Consultants, 1979, Preliminary Seismic Hazard Study, Cañafisto Sites, Cauca River Hidroelectric Proyect. Colombia: San Francisco, California, Woodward-Clyde Consultants unpublished report for Integral Ltda., ISA, Medellín, $97 \mathrm{p}$.

Woodward-Clyde Consultants, 1982, Preliminary Seismic Hazard Study, Alto Sinú Proyect Colombia: San Francisco, California, Woodward-Clyde Consultants unpublished report for ISA and Gomez Cajiao y Asociados, Cia Ltda., Bogotá, $105 \mathrm{p}$.

Woodward-Clyde Consultants, 1983, Seismic Hazard Evaluation Calima III proyect: Consorcio Integral-Planes, Ltda., Ingenieros Consultores 1a parte, Corporación Autónoma Regional del Cauca (CVC), Cali, Colombia, 116 p.

\section{CO-15A, MONTENEGRO (FAULT) SECTION, ROMERAL FAULT SYSTEM}

FAULT SECTION NUMBER/NUMERO DE LA FALLA DE LA SECCION: CO-15a

SECTION NAME/NOMBRE DE LA SECCION: Montenegro (fault)

Comments/Comentarios: Though this fault is part of a larger system, a local name has been used because of its particular geometrical, neotectonic, and morphologic characteristics in the vicinity of Montenegro.

SYNOPSIS AND GEOLOGIC SETTING/SINOPSIS Y AMBIENTE GEOLOGICO: The Montenegro fault is part of the Romeral fault system, running through the western slope of the Cordillera Central. The Montenegro fault is located to the west of the city of Armenia. The fault crosscuts and deforms the Pleistocene volcanic and volcano-sedimentary deposits of the "Quindio fan" (Abanico del Quindío), which covers about $400 \mathrm{~km}^{2}$.

COMPILER, AFFILIATION, \& DATE OF COMPILATION/COMPILADOR, AFILIACION Y FECHA DE COMPILACION: Gabriel Paris, Estudios Geológico Mineros, Cali; June 1998. 
GEOMETRY OF THE SECTION/GEOMETRIA DE LA SECCION:

LENGTH/LONGITUD: $21.7 \mathrm{~km}$ (21.8 km cumulative)

AVERAGE STRIKE/RUMBO PROMEDIO: $25.1^{\circ} \pm 9^{\circ}\left(\mathrm{N} 25.1^{\circ} \mathrm{E} \pm 9^{\circ}\right)$

AVERAGE DIP/INCLINACION PROMEDIO: High to the west

SENSE OF MOVEMENT/SENTIDO DE MOVIMIENTO: Normal sinistral (left-lateral)

Comments/Comentarios: West-side up.

GEOMORPHIC EXPRESSION/EXPRESION GEOMORFOLOGICA: Forms outstanding fault scarps as much as $60 \mathrm{~m}$ in height, beheaded streams, hanging valleys, ponded alluvium, aligned and offset drainages, as well as soil and rock slides on the face of the scarps. Fault deforms Quaternary volcanic debris-flows and ash deposits.

RECURRENCE INTERVAL/INTERVALO DE RECURRENCIA: Unknown

SLIP RATE/TASA DE MOVIMIENTO: $<0.2 \mathrm{~mm} / \mathrm{y}$

Comments/Comentarios: Slip rate is $0.1 \mathrm{~mm} / \mathrm{yr}$ according to Page (1986).

TIME OF MOST RECENT MOVEMENT/EDAD DEL ULTIMO MOVIMIENTO: Quaternary (<1.6 Ma)

REFERENCES/REFERENCIAS

Page, W.D., 1986, Seismic geology and seismicity of Northwestern Colombia: San Francisco, California, WoodwardClyde Consultants Report for ISA and Integral Ltda., Medellín, 200 p.

Paris, G., 1993, Investigación Neotectónica en los Sistemas de Falla de Romeral y Cali-Patía, Departamento del Valle , Colombia: VI Seminario Internacional sobre Ingeniería Sísmica, Universidad de los Andes, Santafé de Bogotá, p. 1-29.

Paris, G., 1977, Fallas Potencialmente Sismogénicas que Pueden Afectar las Obras del Complejo Vial y Cruces a Desnivel de la $2^{\circ}$ con la Avenida Bolivar y de la Cejita con la Avenida República del Libano: Trabajo no publicado realizado para la alcaldía de Armenia, $95 p$.

Thouret, J,C., 1988, La cordillera Centrale des Andes de Colombi et sus Bordures: morphogénése Plio-cuaternaire et dynamique recente et actuelle d'une cordillére glasique et englacée: Thése de Doctorat d'etat, 3 tomos, $p p$ 1040, Université J. Fourier, Granoble, 1988, 132 p.

\section{CO-15B, ARMENIA (FAULT) SECTION, ROMERAL FAULT SYSTEM}

FAULT SECTION NUMBER/NUMERO DE LA FALLA DE LA SECCION: CO-15b

SECTION NAME/NOMBRE DE LA SECCION: Armenia (fault)

Comments/Comentarios: The local name Armenia fault is used because of the fault's particular geometric, neotectonic and morphologic characteristics near Armenia.

SYNOPSIS AND GEOLOGIC SETTING/SINOPSIS Y AMBIENTE GEOLOGICO: The Armenia fault is part of the Romeral fault system on the western slope of the Cordillera Central of Colombia. The fault crosses the city of Armenia and displaces Pliocene-Pleistocene volcanic and volcano-sedimentary deposits of the "Quindio fan" (Abanico del Quindío), which covers about 400 square $\mathrm{km}$. The geometric and neotectonic features of the Montenegro [CO-15a] and Armenia faults are very similar.

COMPILER, AFFILIATION, \& DATE OF COMPILATION/COMPILADOR, AFILIACION Y FECHA DE COMPILACION: Gabriel Paris, Estudios Geológico Mineros, Cali; June 1998. Departamento de Geografía Universidad del Valle, Cali, December 1999.

GEOMETRY OF THE SECTION/GEOMETRIA DE LA SECCION: LENGTH/LONGITUD: About $32 \mathrm{~km}$ (cumulative about $33 \mathrm{~km}$ ).

AVERAGE STRIKE/RUMBO PROMEDIO: $23.2^{\circ} \pm 11^{\circ}\left(\mathrm{N} 23.2^{\circ} \mathrm{E} \pm 11^{\circ}\right)$

AVERAGE DIP/INCLINACION PROMEDIO: Very high to the west

SENSE OF MOVEMENT/SENTIDO DE MOVIMIENTO: Normal sinistral (left-lateral)

Comments/Comentarios: West-side up.

GEOMORPHIC EXPRESSION/EXPRESION GEOMORFOLOGICAL: Forms well developed fault scarp as much as $50 \mathrm{~m}$ high, characterized by beheaded streams, ponded alluvium, aligned and offset drainages, soil and rock slides on the face of the scarp, and localized tilting of terrain. Fault deforms Quaternary volcano-sedimentary debris-flow and pyroclastic flow deposits.

RECURRENCE INTERVAL/INTERVALO DE RECURRENCIA: About 1 k.y. Comments/Comentarios: A maximum moment magnitude of 6.5-6.8 and reccurrence interval of $1 \mathrm{k} . \mathrm{y}$. is estimated for this fault by Paris (1997) based on the length of Quaternary rupture and displacement of topographic features at fault. 
SLIP RATE/TASA DE MOVIMIENTO: $<0.2 \mathrm{~mm} / \mathrm{yr}$

Comments/Comentarios: Slip rate of $0.1 \mathrm{~mm} / \mathrm{yr}$ was based on average scarp height and age of deposit, and degree of preservation of morphotectonic features.

TIME OF MOST RECENT MOVEMENT/EDAD DEL ULTIMO MOVIMIENTO: Holocene/post glacial, $<15 \mathrm{ka}$ Comments/Comentarios: This section has Holocene movement. A trench opened in April 2001 near Circacia, about $20 \mathrm{~km}$ north of Armenia (see inset map), indicates that the fault last movement is younger than 4,820 years (and probably $<3,000 \mathrm{yr}$ ) based on a previously dated bed of lapilli (plinean horizon) that was erupted by the Machín volcano (Espinosa, 2001).

REFERENCES/REFERENCIAS

Espinosa, A., 2001, Estudio de la actividad de la falla de Armenia: Convenio CRQ-Uniquindío, Informe final, Universidad del Quindío, Facultad de Ingeniería, 19 p. (Inédito)

Page, W.D., 1986, Seismic Geology and Seismicity of Northwestern Colombia: San Francisco, California, WoodwardClyde Consultants Report for ISA and Integral Ltda., Medellín, 200 p.

Paris, G., 1993, Investigación Neotectónica en los Sistemas de Falla de Romeral y Cali-Patía, Departamento del Valle, Colombia: VI Seminario Internacional sobre Ingeniería Sísmica, Universidad de los Andes, Santafé de Bogotá, p. 1-29.

Paris, G., y Romero, J., 1994, Fallas Activas en Colombia: INGEOMINAS, Boletin Geológico, v. 34, no. 2-3, p. 3-26 (Santafé de Bogotá).

Paris, G., 1977, Fallas Potencialmente Sismogénicas que Pueden Afectar las Obras del Complejo Vial y Cruces a Desnivel de la $2^{\circ}$ con la Avenida Bolivar y de la Cejita con la Avenida República del Libano: Trabajo no publicado realizado para la alcaldía de Armenia, $95 \mathrm{p}$.

Vergara, H., y Moreno, M., 1997, Actividad Neotectónica en el Departamento del Quindío con énfasis en la Falla de Armenia: Memorias del Seminario de Sismotectónica del Noroccidente Colombiano: INGEOMINAS, Medellín, $13 p$.

\section{CO-15C, PARAISO SECTION, ROMERAL FAULT SYSTEM}

FAULT SECTION NUMBER/NUMERO DE LA FALLA DE LA SECCION: CO-15c SECTION NAME/NOMBRE DE LA SECCION: Paraiso

SYNOPSIS AND GEOLOGIC SETTING/SINOPSIS Y AMBIENTE GEOLOGICO: The Paraiso section is part of the Romeral fault system in southwestern Colombia. It is located at the western slope of the Cordillera Central, east of the city of Palmira. The fault displaces alluvial fans and debris flows on the eastern border of the Valle del Cauca. North of the Amaime River, the fault seems to be more active in late Quaternary than the portion south of the river. Two trenches were opened in the northern part: the Venecia and Piedechinche trenches, each of which show Holocene tectonic deformation.

COMPILER, AFFILIATION, \& DATE OF COMPILATION/COMPILADOR, AFILIACION Y FECHA DE COMPILACION: Gabriel Paris, Department of Geography, Universidad del Valle, Cali; August 1999. From Page 1986

GEOMETRY OF THE SECTION/GEOMETRIA DE LA SECCION:

LENGTH/LONGITUD: $35.3 \mathrm{~km}$ (35.3 km cumulative)

AVERAGE STRIKE/RUMBO PROMEDIO: $12.5^{\circ} \pm 3^{\circ}\left(\mathrm{N} 12.5^{\circ} \mathrm{E} \pm 3^{\circ}\right)$

Comments/Comentarios: Has local variations to the NW and NE.

AVERAGE DIP/INCLINACION PROMEDIO: Varies from $12^{\circ} \mathrm{NE}$ to about $30^{\circ} \mathrm{E}$ SENSE OF MOVEMENT/SENTIDO DE MOVIMIENTO: Thrust fault, minor dextral (right lateral). Comments/Comentarios: Vertical component is east-side up.

GEOMORPHIC EXPRESSION/EXPRESION GEOMORFOLOGICAL: The Paraiso section is concave to the $\mathrm{E}$ and shows an outstanding linear trace for more than $20 \mathrm{~km}$. The fault (section -07c) is divided in two portions: the south portion, about $15 \mathrm{~km}$ long, is located to the south of the Amaime River; the northern portionextends about $7 \mathrm{~km}$ north of the river. Geographic expression suggests that the northern portion is more active than the southern one. The fault is characterized by a series of discontinuos short sinous scarps ( 1 to $2 \mathrm{~km}$ long). The height of the scarps varies from 2 to 10 meters.

RECURRENCE INTERVAL/INTERVALO DE RECURRENCIA: Unknown

SLIP RATE/TASA DE MOVIMIENTO: 0.2-1.0 mm/yr

Comments/ comentarios: Medium slip rate from Page, 1986; the northern section is moderately active, the southern portion is of low to moderate activity. 
TIME OF MOST RECENT MOVEMENT/EDAD DEL ULTIMO MOVIMIENTO: Holocene/post glacial, <15 ka Comments/Comentarios: Two trenches were opened in the northern part of the fault: the Venecia and Piedechinche trenches, each of which show Holocene tectonic deformation. Movement is well defined as early Holocene; according to Page, it is younger than 6,320 yr as determined from C-14 ages of folded paleosoils sampled in the Venecia trench.

REFERENCES/REFERENCIAS

Page, W.D., 1986, Seismic geology and seismicity of Northwestern Colombia: San Francisco, California, WoodwardClyde Consultants Report for ISA and Integral Ltda., Medellín, 200 p.

\section{CO-15D, PIENDAMÓ (FAULT) SECTION, ROMERAL FAULT SYSTEM}

FAULT SECTION NUMBER/NUMERO DE LA FALLA DE LA SECCION: CO-15d SECTION NAME/NOMBRE DE LA SECCION: Piendamó (fault)

SYNOPSIS AND GEOLOGIC SETTING/SINOPSIS Y AMBIENTE GEOLOGICO: The Piendamó fault (section) is part of Romeral fault system in southwestern Colombia; it is located at the base of the mountain front of the western slope of the Cordillera Central, north of the city of Popayán. The fault displaces volcanic pyroclastic deposits and mud flows of the Tertiary-Quaternary Popayán Formation. It forms an outstanding topographic and tectonic block bounded by two intersecting faults.

COMPILER, AFFILIATION, \& DATE OF COMPILATION/COMPILADOR, AFILIACION Y FECHA DE COMPILACION: Gabriel Paris, Estudios Geológico Mineros, Cali; June 1998; Departamento de Geografía, Universidad del Valle, Cali, December 1999.

GEOMETRY OF THE SECTION/GEOMETRIA DE LA SECCION: LENGTH/LONGITUD: $28.3 \mathrm{~km}$ (28.9 km cumulative)

AVERAGE STRIKE/RUMBO PROMEDIO: $-8.4^{\circ} \pm 18^{\circ}\left(\mathrm{N} 8.4^{\circ} \mathrm{W} \pm 18^{\circ}\right)$

Comments/Comentarios: Strike is variable, ranging from $\mathrm{N} 40^{\circ} \mathrm{W}$ in the southern part to about $\mathrm{N} 10^{\circ} \mathrm{E}$ in the northern part.

AVERAGE DIP/INCLINACION PROMEDIO: Probably medium to high angle to the east and northeast. Comments/Comentarios: Dip based on observations from several years of regional field work by Gabriel Paris in northern Cauca area.

SENSE OF MOVEMENT/SENTIDO DE MOVIMIENTO: Reverse dextral (right-lateral)

Comments/Comentarios: The deflection of creeks and gullies indicates dextral movement with east-side up.

GEOMORPHIC EXPRESSION/EXPRESION GEOMORFOLOGICA: Forms an outstanding prismatic-tectonic mountain block comprised of pyroclastic flow and ash-fall deposits. This block is bounded by two well developed fault scarps of about $400 \mathrm{~m}$ (maximum) height; one facing WSW and the other facing SSW. There is geomorphic evidence of scarp degradation and old landslides on the face of these scarps. Deep canyons cut about $200 \mathrm{~m}$ into scarps formed against a flat-topped $400-\mathrm{m}$-high mountain. Several close fault lines parallel the WSW-facing scarp. The $400 \mathrm{~m}$-high Piendamo scarp is one of the largest for neotectonic (Quaternary) faults in western Colombia.

RECURRENCE INTERVAL/INTERVALO DE RECURRENCIA: Unknown

SLIP RATE/TASA DE MOVIMIENTO: 0.2-1 mm/yr

Comments/Comentarios: Low to medium rate based on the state of preservation of geomorphic features and height of scarps.

TIME OF MOST RECENT MOVEMENT/EDAD DEL ULTIMO MOVIMIENTO: Quaternary(?), <1.6 Ma REFERENCES/REFERENCIAS

Page, W.D., 1986, Seismic geology and seismicity of Northwestern Colombia: San Francisco, California, WoodwardClyde Consultants Report for ISA and Integral Ltda., Medellín, 200 pp

Paris, G., y Souret, B., 1993, Microzonificación Sismogeotécnica de Popayán. Subproyecto Neotectónica. Proyecto Colombo-Europeo No. CCE NA 84/03: Comunidad Economica Europea-INGEOMINAS-BRGM-ADK-KS, Publicaciones Especiales de INGEOMINAS, no. 2, p. 28-49, Bogotá.

Paris, G., y Romero, J., 1994, Fallas Activas en Colombia: INGEOMINAS, Boletin Geológico, v. 34, no. 2-3, p. 3-26 (Santafé de Bogotá).

Woodward-Clyde Consultants, 1983, Seismic Hazard Evaluation Calima III proyect: Consorcio Integral-Planes, Ltda., Ingenieros Consultores 1a parte, Corporación Autónoma Regional del Cauca (CVC), Cali, Colombia, 116 p. 


\section{CO-15E, ROSAS-JULUMITO (FAULT) SECTION, ROMERAL FAULT SYSTEM}

FAULT SECTION NUMBER/NUMERO DE LA FALLA DE LA SECCION: CO-15e

SECTION NAME/NOMBRE DE LA SECCION: Rosas-Julumito (fault)

SYNOPSIS AND GEOLOGIC SETTING/SINOPSIS Y AMBIENTE GEOLOGICO: The Rosas-Julimito fault is part of the much longer Romeral fault system. It is a rather short section of about $43 \mathrm{~km}$ length, $17 \mathrm{~km}$ of which have active movement. The fault section parallels the Cauca-Almaguer fault, which is one of the largest older fracture zones in western Colombia. The Rosas-Julimito fault is about $5 \mathrm{~km}$ west of the city of Popayan. The fault crosses the Pliocene-Pleistocene Popayán Formation, which consists of pyroclastic-flow, mud-flow and ash-fall deposits. It is believed that either the Rosas fault or the nearby Julumito fault ( $<2 \mathrm{~km}$ to the west) produced the earthquake of March 31, 1983 that partially destroyed the city of Popayan.

COMPILER, AFFILIATION, \& DATE OF COMPILATION/COMPILADOR, AFILIACION Y FECHA DE COMPILACION: Gabriel Paris, Estudios Geológico Mineros, Cali; August 1997.

TYPE OF STUDIES: Morphotectonics, microtectonics, and detailed neotectonic field work. Exploratory trenches were excavated across the fault.

GEOMETRY OF THE SECTION/GEOMETRIA DE LA SECCION:

LENGTH/LONGITUD: $43.3 \mathrm{~km}$ (43.6 km cumulative)

AVERAGE STRIKE/RUMBO PROMEDIO: $26.9^{\circ} \pm 7^{\circ}\left(\mathrm{N} 26.9^{\circ} \mathrm{E} \pm 7^{\circ}\right)$

AVERAGE DIP/INCLINACION PROMEDIO: Moderate to high angle to the west.

Comments/Comentarios: Estimated from sheared deposits in the Timbío trench by Paris and Sauret (1993).

SENSE OF MOVEMENT/SENTIDO DE MOVIMIENTO: Reverse, dextral (right-lateral)

Comments/Comentarios: Based on WSW-ENE compressional stress field, calculated from focal mechanism solution, and microtectonics work. West side is up.

GEOMORPHIC EXPRESSION/EXPRESION GEOMORFOLOGICA: The fault section runs through the smooth but hilly topography that is formed by sediment of the Popayan Formation. The fault morphology is easily observed on aerial photographs and satellite images and from aircraft. The most noticeable features are fault saddles, ponded Quaternary alluvial valleys, stream deflections, offset drainages, linear fault ridges, and shutter ridges. Beyond the Popayan Formation, where the fault is in older rock formations, the topographic expression of the fault is still noticeable. The active portion of the fault is only about $17 \mathrm{~km}$ long.

RECURRENCE INTERVAL/INTERVALO DE RECURRENCIA: 7-70 k.y.

Comments/Comentarios: A maximum moment magnitude of 6.8 is assumed for this fault using only $17 \mathrm{~km}$ for its probable total surface rupture length.

SLIP RATE/TASA DE MOVIMIENTO: 0.2-1 mm/yr

Comments/Comentarios: Low to medium rate estimated from the degree of preservation of neotectonic landforms and offset streams.

TIME OF MOST RECENT MOVEMENT/EDAD DEL ULTIMO MOVIMIENTO: Historic (1983)

Comments/Comentarios: During the 1983 earthquake, several cracks with generally north trends developed at the surface in an area 2-km wide and 2.5-km long, north of Popayán. Individual cracks were a few meters to tens of meters long and few milimeters in width.

NAME OF EARTHQUAKE/NOMBRE DEL TERREMOTO: Popayan Earthquake of 31 March 1983 Comments/Comentarios: The Associated Press reported about 300 deaths from this earthquake.

DATE/FECHA: 3/31/83, Time 13:13

DEPTH/PROFUNDIDAD: $12 \mathrm{~km}$

MAGNITUDE OR INTENSITY/MAGNITUD O INTENSIDAD: Mb 5.5

REFERENCES/REFERENCIAS

INGEOMINAS, 1986, "El sismo de Popayán del 31 de Marzo de 1983": INGEOMINAS, Bogotá, 320 p.

Page, W.D., 1983, Popayan Earthquake of 31 March 1983: Geological and seismological aspects, 9 p. (unpublished report ).

Page, W.D., 1986, Seismic geology and seismicity of Northwestern Colombia: San Francisco, California, WoodwardClyde Consultants Report for ISA and Integral Ltda., Medellín, 200 pp 
Paris, G., Marin, P., Romero, J., y Wagner, J, J., 1989, “Actividad Neotectónica en el Suroccidente Colombiano": Memorias $5^{\circ}$ Congreso Colombiano de Geología, Bucaramanga, Marzo 14-17, Soc. Col. de Geol., p. $193-213$ (Bogotá).

Paris, G., y Souret, B., 1993, Microzonificación Sismogeotécnica de Popayán. Subproyecto Neotectónica. Proyecto Colombo-Europeo No. CCE NA 84/03: Comunidad Economica Europea-INGEOMINAS-BRGM-ADK-KS, Publicaciones Especiales de INGEOMINAS, no. 2, p. 28-49, Bogotá.

Sarria, A., 1990, Ingeniería Sísmica: Bogotá, Universidad de los Andes, Facultad de Ingeniería, Departamento de Ingeniería Civil, Edición Uniandes, 610 p. (Bogotá).

Woodward-Clyde Consultants, 1983, Seismic Hazard Evaluation Calima III proyect: Consorcio Integral-Planes, Ltda., Ingenieros Consultores 1a parte, Corporación Autónoma Regional del Cauca (CVC), Cali, Colombia, 116 p.

\section{CO-15F, CORDOBA-NAVARCO (FAULT) SECTION, ROMERAL FAULT SYSTEM}

FAULT SECTION NUMBER/NUMERO DE LA FALLA DE LA SECCION: CO-15f

SECTION NAME/NOMBRE DE LA SECCION: Cordoba and Navarco (fault)

SYNOPSIS AND GEOLOGIC SETTING/SINOPSIS Y AMBIENTE GEOLOGICO: This section of the fault system is formed by the Cordoba and Navarco faults (local names), which are eastern strands of Romeral fault system, south of the city of Armenia. These faults are only approximately located on the map, but lie within the epicenter area of the Armenia earthquake of January 25,1999. The faults extend through sheared cataclastic and undeformed basaltic and sedimentry Cretaceous oceanic rocks, cropping out on the eastern slope of the Cordillera Central of Colombia.

COMPILER, AFFILIATION, \& DATE OF COMPILATION/COMPILADOR, AFILIACION Y FECHA DE COMPILACION: Gabriel Paris, Departamento de Geografía, Universidad del Valle, Cali, December 1999.

GEOMETRY OF THE SECTION/GEOMETRIA DE LA SECCION:

LENGTH/LONGITUD: $21.2 \mathrm{~km}$ (21.2 km cumulative)

AVERAGE STRIKE/RUMBO PROMEDIO: $18.5^{\circ} \pm 4^{\circ}\left(\mathrm{N} 18.5^{\circ} \mathrm{E} \pm 4^{\circ}\right)$

AVERAGE DIP/INCLINACION PROMEDIO: Vertical

Comments/Comentarios: See INGEOMINAS (1999c).

SENSE OF MOVEMENT/SENTIDO DE MOVIMIENTO: Sinistral (left lateral)

Comments/Comentarios: Offset and deflected streams in a sinistral sense.

GEOMORPHIC EXPRESSION/EXPRESION GEOMORFOLOGICA: Well preserved fault trace controls stream draingages. Forms fault saddles and eroded fault scarps. Neotectonic features are not very outstanding. Slopes in this part of the Cordillera Central are rather steep, so erosion rate is high.

RECURRENCE INTERVAL/INTERVALO DE RECURRENCIA: Unknown

RATE/TASA DE MOVIMIENTO: $<0.2 \mathrm{~mm} / \mathrm{yr}$

Comments/Comentarios: Rate is likely low to very low $(<0.2 \mathrm{~mm} / \mathrm{yr})$ based on poor development of morpho-neotectonic features.

TIME OF MOST RECENT MOVEMENT/EDAD DEL ULTIMO MOVIMIENTO: Historic (1999)

Comments/Comentarios: This earthquake caused extensive damage and ground deformation in the epicentral region.

NAME OF EARTHQUAKE/NOMBRE DEL TERREMOTO: Armenia (1999).

DATE/FECHA: 1/25/99 TME 13:19

DEPTH/PROFUNDIDAD: $12-15 \mathrm{~km}$

MAGNITUDE OR INTENSITY/MAGNITUD O INTENSIDAD: Ms 6.2

LENGTH OF SURFACE RUPTURE/LONGITUD DE RUPTURA: Although no surface rupture was observed, the near surface rupture was about $20 \mathrm{~km}$ long as estimated from the NNE-SSW distribution of epicenters.

REFERENCES/REFERENCIAS

INGEOMINAS, 1999a, Terremoto del Quindío (Enero 25 de 1999). Informe tecnico No.2, Armenia, Santafé de Bogotá, $52 p$.

INGEOMINAS, 1999b, Terremoto del Quindío (Enero 25 de 1999). Informe técnico preliminar No 3, Evaluación de los daños, en Calarcá, Pijao y Cordoba, Santafé de Bogotá, 35pp

INGEOMINAS, 1999c, Analisis de la secuencia de réplicas del sismo del 25 de Enero de 1999, con base en una red, sismológica local (Enero 26-Marzo31) Zonificación sismogeotécnica indicativa para la reconstrucción de Armenia, Vol. 1, 84p. 


\section{CO-15G, BUESACO-ARANDA (FAULT) SECTION, ROMERAL FAULT SYSTEM}

FAULT SECTION NUMBER/NUMERO DE LA FALLA DE LA SECCION: CO-15g

SECTION NAME/NOMBRE DE LA SECCION: Buesaco-Aranda (fault)

Comments/Comentarios: Though the Buesaco and Aranda faults belong to the Romeral Fault System, they were studied separatedly in detail by Tibaldi and Romero (2000), focusing on the fault's morphotectonic characteristics near Buesaco, a few kilometers to the NE of Pasto where it shows outstanding neotectonic features.

SYNOPSIS AND GEOLOGIC SETTING/SINOPSIS Y AMBIENTE GEOLOGICO: The Buesaco-Aranda faults, which are parallel, extend in a NNE to NE direction from near the Galeras volcano in SW Colombia. The Buesaco fault is located $5 \mathrm{~km}$ to the west of the Aranda fault. On the eastern block of the Buesaco fault, the basement rock consists of basic volcanic, andesite and dark sedimentary rocks which probably developed in a marginal basin environment during early Cretaceous time (Nivia and others, 1996). On the western block of the fault are a group of low-grade metamorphic rocks which consist of greenschist, anphibolite, quartzite and black schist, all of Paleozoic age. The area is mostly covered by a Pliocene blanket of pyroclastic rocks and calc-alkalin lavas, Quaternary lahars and fluvioglacial deposits.

COMPILER, AFFILIATION, \& DATE OF COMPILATION/COMPILADOR, AFILIACION Y FECHA DE COMPILACION: Gabriel Paris, Departamento de Geografia Universidad del Valle, Cali, January 2001.

GEOMETRY OF THE SECTION/GEOMETRIA DE LA SECCION:

LENGTH/LONGITUD: $29 \mathrm{~km}$ (cumulative $29 \mathrm{~km}$ )

AVERAGE STRIKE/RUMBO PROMEDIO: NE-SW

AVERAGE DIP/INCLINACION PROMEDIO: Vertical and high angle to the west

SENSE OF MOVEMENT/SENTIDO DE MOVIMIENTO: Dextral (right lateral)

Comments/Comentarios: Fault plane solution from historic seismic event (see below) on fault section indicates normal-dextral faulting on a plane striking $N 53^{\circ} \mathrm{E}$ and dipping $73^{\circ} \mathrm{W}$ (Ingeominas, 1995).

GEOMORPHIC EXPRESSION/EXPRESION GEOMORFOLOGICAL: Very outstanding fault line trace, strongly deformed landforms of Pleistocene-Holocene age, clear break on slopes of eroded fault scarps, and fault scarps facing either SE or NW, which are characteristic of transcurrent faults. Systemmatic right lateral deflections of some stream gullies, river channels, and ridges. Offsets features in confined alluvial deposits and in recent alluvial fans have fresh scarp morphology. Net cumulative horizontal slip calculated is $188 \pm 14 \mathrm{~m}$ (Tibaldi and Romero, 2000), with $160 \pm 10 \mathrm{~m}$ of displacement in offset landforms along the Aranda fault

RECURRENCE INTERVAL/INTERVALO DE RECURRENCIA: Unknown Comments/Comentarios:

SLIP RATE/TASA DE MOVIMIENTO: $1-5 \mathrm{~mm} / \mathrm{yr}$ Comments/Comentarios: Estimate of $1.2 \mathrm{~mm} / \mathrm{yr}$ from offset Quaternary morphologic features (see Tibaldi and Romero, 2000).

TIME OF MOST RECENT MOVEMENT/EDAD DEL ULTIMO MOVIMIENTO: Historic (1995) Comments/Comentarios: The last strong seismic event occurred on the Buesaco fault on March 4, 1995; the coda duration magnitude of the biggest shock was M 5.1 (local Richter magnitude, Ingeominas, 1995). REFERENCES/REFERENCIAS

Ingeominas, 1995, El Sismo de Pasto (Nariño) del 4 de Marzo de 1995: Bol. de Sismos, 3(1) Jan-March, p. 63-70, Bogotá.

Nivia,A., Marriner, G., and Kerr, A.,1996, El Complejo Quebradagrande una posible cuenca marginal intracratonica del Cretaceo inferior en la cordillera de los Andes colombianos. VII Congreso Colombiano de Geología,III,108-123

Tibaldi, A., And Romero, J., 2000, Morphometry of late Pleistocene-Holocene faulting and volcanotectonic relationship in the southern Andes of Colombia: Tectonics, v. 19, p. 358-377.

\section{CO-16, SANTA RITA FAULT}

FAULT NUMBER/NUMERO DE LA FALLA: CO-16

FAULT NAME/NOMBRE DE LA FALLA: Santa Rita (Romeral fault system)

SYNOPSIS AND GEOLOGIC SETTING/SINOPSIS Y AMBIENTE GEOLOGICO: The Santa Rita fault displaces metamorphosed volcanic and sedimentary rocks through most of its length; in the northern part, the fault 
places Cretaceous basic volcanic rocks against Tertiary and Quaternary sedimentary rocks. To the south, the Santa Rita fault intercepts the Espiritu Santo fault [CO-17].

COMPILER, AFFILIATION, \& DATE OF COMPILATION/COMPILADOR, AFILIACION Y FECHA DE COMPILACION: Gabriel Paris, INGEOMINAS, Cali; August, 1993. Revised by Gabriel Paris, Estudios Geológico Mineros, Cali; June 1998.

TYPE OF STUDIES/TIPOS DE ESTUDIOS. Interpretation of aerial photographs, regional and detailed local geologic field studies, geomorphology and instrumental seismology.

GEOMETRY OF THE FAULT/GEOMETRIA DE LA FALLA:

LENGTH/LONGITUD: $81.0 \mathrm{~km}$ (81.3 km cumulative)

AVERAGE STRIKE/RUMBO PROMEDIO: $10.6^{\circ} \pm 6^{\circ}\left(\mathrm{N} 10.6^{\circ} \mathrm{E} \pm 6^{\circ}\right)$

AVERAGE DIP/INCLINACION PROMEDIO: High angle to the east.

SENSE OF MOVEMENT/SENTIDO DE MOVIMIENTO: Sinistral (left-lateral)

Comments/Comentarios: Compatible with NW-SE compressional stress field in this area.

GEOMORPHIC EXPRESSION/EXPRESION GEOMORFOLOGICA: Well-defined fault trace seen on satellite images. The trace is characterized by linear valleys, strong breaks in slope, offset alluvial fans and colluvial deposits, and local subsidence of the soil.

RECURRENCE INTERVAL/INTERVALO DE RECURRENCIA: 20-200 k.y. Comments/Comentarios: Estimated from slip rate and maximum probable magnitude.

SLIP RATE CATEGORY/CATEGORICA DE TASA DE MOVIMIENTO: $<0.2 \mathrm{~mm} / \mathrm{yr}$ Comments/Comentarios: Low rate of $0.01-0.1 \mathrm{~mm} / \mathrm{yr}$ is based on preservation of morphotectonic features.

TIME OF MOST RECENT MOVEMENT/EDAD DEL ULTIMO MOVIMIENTO: Quaternary, <1.6 Ma Comments/Comentarios: This fault might be the source of a historic M 4.8 earthquake (information taken from seismic catalog).

REFERENCES/REFERENCIAS

Page, W.D., 1986, Seismic geology and seismicity of Northwestern Colombia: San Francisco, California, WoodwardClyde Consultants Report for ISA and Integral Ltda., Medellín, 200 p.

Paris, G., y Romero, J., 1994, Fallas Activas en Colombia: INGEOMINAS, Boletin Geológico, v. 34, no. 2-3, p. 3-26 (Santafé de Bogotá).

Woodward-Clyde Consultants, 1980, Phase I, Preliminary Seismic Hazard Study Ituango Proyect, Colombia: San Francisco, California, Woodward-Clyde Consultants unpublished report for Integral Ltda., and ISA, Medellín 97 p.

\section{CO-17, ESPIRITU SANTO FAULT}

FAULT NUMBER/NUMERO DE LA FALLA: CO-17

FAULT NAME/NOMBRE DE LA FALLA: Espiritu Santo

SYNOPSIS AND GEOLOGIC SETTING/SINOPSIS Y AMBIENTE GEOLOGICO: One of the more prominent

Cenozoic faults in the northern Cordillera Central of Colombia. The Espiritu Santo fault extends from the Sabanalarga fault near the town of Liborina (in the southwest), as far northeast as the town of Caceres in the Bajo Cauca area. There, it disappears under young sediment of the Cauca and Nechi river valleys. It has a reverse sense in the northern part and normal sense in the southern part. The Espiritu Santo fault places Precambrian metamorphic rocks to the south against Paleozoic metamorphic rocks to the north. The fault displaces rocks of the Puquí complex, Valdivia group, and mafic and ultramafic rocks and sediments of the Bajo Cauca.

COMPILER, AFFILIATION, \& DATE OF COMPILATION/COMPILADOR, AFILIACION Y FECHA DE COMPILACION: Gabriel Paris, INGEOMINAS, Cali; August, 1993. Revised by Gabriel Paris, Estudios Geológico Mineros, Cali; June 1998.

TYPE OF STUDIES/TIPOS DE ESTUDIOS: Interpretation of aerial photographs and satellite images, general and detailed geologic field studies, as well as morphotectonics, neotectonics, and instrumental local seismicity. Integral (1998) reported results from five trenches.

GEOMETRY OF THE FAULT/GEOMETRIA DE LA FALLA:

LENGTH/LONGITUD: $124.4 \mathrm{~km}$ (124.9 km cumulative)

AVERAGE STRIKE/RUMBO PROMEDIO: $33.9^{\circ} \pm 5^{\circ}\left(\mathrm{N} 33.9^{\circ} \mathrm{E} \pm 5^{\circ}\right)$

AVERAGE DIP/INCLINACION PROMEDIO: Mainly vertical, high angle to the northwest 
SENSE OF MOVEMENT/SENTIDO DE MOVIMIENTO: Normal and oblique dextral

Comments/Comentarios: Vertical component is east-side up. According to Integral (1998), the focal mechanisms of local seismicity show normal and dextral fault movements, which correspond to results of neotectonic field studies.

GEOMORPHIC EXPRESSION/EXPRESION GEOMORFOLOGICA: Well developed fault lines and valleys. Trace marked by young morphologic features such as ground ruptures, saddles, shutter ridges, closed depressions, aligned and captured drainages and linear scarps on recent sediment (Integral, 1998) There is clear offset of 50-100 k.y. old terraces and Quaternary deposits around "El Doce". In addition, the fault has displaced a Tertiary erosion surface.

RECURRENCE INTERVAL/INTERVALO DE RECURRENCIA: 2-5 k.y.

Comments/Comentarios: Estimated from slip rate and maximum probable magnitude. INGEOMINAS calculated a maximum probable magnitude of Mw 6-6.5 taking into account only the length of neotectonic features along the fault trace.

SLIP RATE/TASA DE MOVIMIENTO: 0.2-1 mm/yr

Comments/Comentarios: Long-term rate of $0.3-0.4 \mathrm{~mm} / \mathrm{yr}$ based on offset of Tertiary erosion surface (Integral, 1998).

TIME OF MOST RECENT MOVEMENT/EDAD DEL ULTIMO MOVIMIENTO: Holocene/post glacial, $<15$ ka Comments/Comentarios: Activity is Holocene. According to Integral (1998), last movement was about 500 yrs ago, with no more recent activity.

REFERENCES/REFERENCIAS

Integral, 1998, Proyecto Hidroélectrico del Nechí. Sismologia. Informe final. Evaluación de la amenaza sismica. Documento No 3045-04 rev 0. Consorcio Integral-Sedic, 130 p.

Page, W.D., 1986, Seismic geology and seismicity of Northwestern Colombia: San Francisco, California, WoodwardClyde Consultants Report for ISA and Integral Ltda., Medellín, 200 p.

Paris, G., y Romero, J., 1994, Fallas Activas en Colombia: INGEOMINAS, Boletin Geológico, v. 34, no. 2-3, p. 3-26 (Santafé de Bogotá).

Ramirez, J.E., 1975, "Historia de los Terremotos de Colombia", Seg. E.: Instituto Geográfico Agustín Codazzi, 250 p. (Bogotá).

Woodward-Clyde Consultants, 1980, Phase I, Preliminary Seismic Hazard Study Ituango Proyect, Colombia: San Francisco, California, Woodward-Clyde Consultants unpublished report for Integral Ltda., and ISA, Medellín 97 p.

\section{CO-18, OTU NORTE FAULT}

FAULT NUMBER/NUMERO DE LA FALLA: CO-18

FAULT NAME/NOMBRE DE LA FALLA: Otú Norte

SYNOPSIS AND GEOLOGIC SETTING/SINOPSIS Y AMBIENTE GEOLOGICO: The Otú Norte fault strikes SSE and appears to offset the La Palestina fault [CO-20] (see Page, 1986). The Otú fault extends in a northwest direction to near Bajo Nechí, where it is covered by young Quaternary deposits. The fault separates blocks of totally dissimilar geology and lithology: Precambrian and Ordovician rocks on the east are juxtaposed against arc rocks on the west. The northern end apparently splays into several faults that cross the Nechi River.

COMPILER, AFFILIATION, \& DATE OF COMPILATION/COMPILADOR, AFILIACION Y FECHA DE COMPILACION: Gabriel Paris, Departamento de Geografía Universidad del Valle, January 2000.

TYPE OF STUDIES/TIPOS DE ESTUDIOS: Geologic reconnaissance by Page (1986).

GEOMETRY OF THE FAULT/GEOMETRIA DE LA FALLA:

LENGTH/LONGITUD: $144.4 \mathrm{~km}$ (139.1 km cumulative)

AVERAGE STRIKE/RUMBO PROMEDIO: $-13.4^{\circ} \pm 8^{\circ}\left(\mathrm{N} 13.4^{\circ} \mathrm{W} \pm 8^{\circ}\right)$

AVERAGE DIP/INCLINACION PROMEDIO: Probably high to the east

SENSE OF MOVEMENT/SENTIDO DE MOVIMIENTO: Sinistral (left lateral) reverse

Comments/Comentarios: Vertical component is east-side up. Attitude is assumed from similar general behavior of neighbouring faults, such as the Palestina fault [CO-20] (see Page's map, 1986).

GEOMORPHIC EXPRESSION/EXPRESION GEOMORFOLOGICA: The fault is prominent on satellite images and aerial photographs.

RECURRENCE INTERVAL/INTERVALO DE RECURRENCIA: Unknown 
SLIP RATE/TASA DE MOVIMIENTO: $<0.2 \mathrm{~mm} / \mathrm{yr}$

Comments/Comentarios: A low to very low rate $(<0.2 \mathrm{~mm} / \mathrm{yr})$ was estimated by Page (1986).

TIME OF MOST RECENT MOVEMENT/EDAD DEL ULTIMO MOVIMIENTO: Quaternary (<1.6 Ma) Comments/Comentarios: Displaced Quaternary terraces as high as $140 \mathrm{~m}$ are reported by Shlemon (1970, cited in Page, 1986) and the fault offsets the Tertiary erosion surface of the Cordillera Central (Page, 1986).

REFERENCES/REFERENCIAS

Mann, P., and Burke, K., 1984, Neotectonics of the Caribbean: Rev. Geophys., v. 22, p. 309-362,

Page, W.D., 1986, Seismic geology and seismicity of Northwestern Colombia: San Francisco, California, WoodwardClyde Consultants Report for ISA and Integral Ltda., Medellín, 200 p.

\section{CO-19, BAGRE NORTE FAULT}

FAULT NUMBER/NUMERO DE LA FALLA: CO-19

FAULT NAME/NOMBRE DE LA FALLA: Bagre Norte

SYNOPSIS AND GEOLOGIC SETTING/SINOPSIS Y AMBIENTE GEOLOGICO: The Bagre Norte fault branches from La Palestina fault [CO-20] (Page, 1986) close to the Alicante River. The fault juxaposes Precambrian metamorphic rocks on the east against sedimentary rocks on the west.

COMPILER, AFFILIATION, \& DATE OF COMPILATION/COMPILADOR, AFILIACION Y FECHA DE COMPILACION: Gabriel Paris, Departamento de Geografía Universidad del Valle, January 2000.

TYPE OF STUDIES/TIPOS DE ESTUDIOS: Geologic reconnaissance by Page (1986).

GEOMETRY OF THE FAULT/GEOMETRIA DE LA FALLA:

LENGTH/LONGITUD: $159.3 \mathrm{~km}$ (160.9 km cumulative)

AVERAGE STRIKE/RUMBO PROMEDIO: $-1.0^{\circ} \pm 14^{\circ}\left(\mathrm{N} 1.0^{\circ} \mathrm{W} \pm 14^{\circ}\right)$

AVERAGE DIP/INCLINACION PROMEDIO: Probably high to the east

Comments/Comentarios: Estimated on basis of the general behavior of neighboring faults (Page, 1986).

SENSE OF MOVEMENT/SENTIDO DE MOVIMIENTO: Sinistral (left lateral) and reverse.

Comments/Comentarios: Vertical component is east-side up.

GEOMORPHIC EXPRESSION/EXPRESION GEOMORFOLOGICA: The fault shows as a prominent topographic lineament on satellite images and aerial photographs. Prominent scarp faces west, fault appears to displace erosion surface of the Cordillera Central about $200 \mathrm{~m}$ (Page, 1986). The strong geomorphic expression suggests Quaternary activity.

RECURRENCE INTERVAL/INTERVALO DE RECURRENCIA: Unknown

SLIP RATE/TASA DE MOVIMIENTO: <0.2-1 mm/yr

Comments/Comentarios: Low rate as estimated by Page (1986)

TIME OF MOST RECENT MOVEMENT/EDAD DEL ULTIMO MOVIMIENTO: Quaternary (<1.6 m.y.) Comments/Comentarios: Inferred by Page (1986) because of its strong geomorphic expression. REFERENCES/REFERENCIAS

Page, W.D., 1986, Seismic geology and seismicity of Northwestern Colombia: San Francisco, California, WoodwardClyde Consultants Report for ISA and Integral Ltda., Medellín, 200 p.

\section{CO-20, PALESTINA FAULT}

FAULT NUMBER/NUMERO DE LA FALLA: CO-20

FAULT NAME/NOMBRE DE LA FALLA: Palestina

SYNOPSIS AND GEOLOGIC SETTING/SINOPSIS Y AMBIENTE GEOLOGICO: The Palestina fault extends from the Departamento (state) of Antioquia in the north to the Nevado del Ruiz (volcanic) zone in the south. It mainly extends along the eastern slope of the Cordillera Central of Colombia, displacing Paleozoic crystalline metamorphic rocks and, in lesser amounts, Mesozoic plutonic rocks. The oldest rocks are mainly in the western block, which elevates a probable Miocene erosion surface whose eroded remnants are characterized by aligned flat narrow benches and spurs.

COMPILER, AFFILIATION, \& DATE OF COMPILATION/COMPILADOR, AFILIACION Y FECHA DE COMPILACION: Gabriel Paris, INGEOMINAS, Bogotá; November 1993. Reviewed January 1997 at CRQ and UNIQUINDIO, Armenia. Revised by Gabriel Paris, Estudios Geológico Mineros, Cali; June 1998. 
TYPE OF STUDIES/TIPOS DE ESTUDIOS: General interpretation of aerial photographs, regional geologic field studies, and local microtectonic and morphotectonic studies.

GEOMETRY OF THE FAULT/GEOMETRIA DE LA FALLA:

LENGTH/LONGITUD: $369.6 \mathrm{~km}$ (430.6 km cumulative)

AVERAGE STRIKE/RUMBO PROMEDIO: $17.8^{\circ} \pm 11^{\circ}\left(\mathrm{N} 17.8^{\circ} \mathrm{E} \pm 11^{\circ}\right)$

AVERAGE DIP/INCLINACION PROMEDIO: Moderate to high angle to the west

Comments/Comentarios: On some strands, east side is up to the west.

SENSE OF MOVEMENT/SENTIDO DE MOVIMIENTO: Sinistral (left lateral), reverse.

Comments/Comentarios: Generally has west-side up, but some exposures show reverse faulting with the east-side up.

GEOMORPHIC EXPRESSION/EXPRESION GEOMORFOLOGICA: Forms outstanding slope break between the western uplifted block and the eastern peneplain surface. In the western block, there are flat benchlike remnants of a Tertiary (Miocene?) erosion surface. The fault zone is characterized by fault scarps, saddles, linear ridges, displaced streams, shutter ridges, and aligned springs. Some topographic features show evidence of sinistral offset. Locally two fault traces bound a depressed block (pull-apart graben). Based on stratigraphic evidence, Feininger (1970) reported dextral movement of about $15 \mathrm{~km}$, which probably occurred before Quaternary time. However, the Quaternary movement is believed to be sinistral. Before Miocene time, most of the faults of northern and western Colombia probably had dextral movement.

RECURRENCE INTERVAL/INTERVALO DE RECURRENCIA: Unknown

SLIP RATE/TASA DE MOVIMIENTO: 0.2-1 mm/yr

Comments/Comentarios: Slip rate of $0.2 \mathrm{~mm} / \mathrm{yr}$ estimated on basis of geomorphic features and displacement of a Tertiary erosion surface (pre-Mesa Formation).

TIME OF MOST RECENT MOVEMENT/EDAD DEL ULTIMO MOVIMIENTO: Quaternary, <1.6 Ma REFERENCES/REFERENCIAS

Feininger, T., 1970, The Palestina fault, Colombia: Geological Society of America Bulletin, v. 81, p.1201-1216.

Page, W.D., 1986, Seismic geology and seismicity of Northwestern Colombia: San Francisco, California, WoodwardClyde Consultants Report for ISA and Integral Ltda., Medellín, 200 p.

Paris, G., y Romero, J., 1994, Fallas Activas en Colombia: INGEOMINAS, Boletin Geológico, v. 34, no. 2-3, p. 3-26 (Santafé de Bogotá).

Vergara, H., Paris, G., Taboada, A., Romero, y J., Castro, E., 1996, Actividad Neotectónica en las Fuentes Sismogénicas de la Región Central de Colombia: Memorias VII $\left(7^{\text {th }}\right)$ Congreso Colombiano de Geología, INGEOMINAS, Santafé de Bogotá, Colombia, 13 .

\section{CO-21, CIMITARRA FAULT}

FAULT NUMBER/NUMERO DE LA FALLA: CO-21

FAULT NAME/NOMBRE DE LA FALLA: Cimitarra

SYNOPSIS AND GEOLOGIC SETTING/SINOPSIS Y AMBIENTE GEOLOGICO: The Cimitarra fault departs (splays) from the Palestina fault [CO-20] in a northeasterly direction on the eastern border of the Cordillera Central. The fault displaces Jurassic-Cretaceous volcanic rocks, Mesozoic igneous rocks, a Tertiary erosion surface in the Cordillera Central, and late Quaternary sediments. Portions of the fault are prePliocene in age since it is locally covered by undeformed Pliocene sediments. Farther northeast, the fault is overlain by young alluvial deposits of the middle Magdalena Valley.

COMPILER, AFFILIATION, \& DATE OF COMPILATION/COMPILADOR, AFILIACION Y FECHA DE COMPILACION: Gabriel Paris, INGEOMINAS, Bogotá; November 1993. Reviewed January 1997 at CRQ and UNIQUINDIO, Armenia. Revised by Gabriel Paris, Estudios Geológico Mineros, Cali; June 1998.

TYPE OF STUDIES/TIPOS DE ESTUDIOS: Interpretation of aerial photographs, and reconnaissance morphotectonic and neotectonic field studies.

GEOMETRY OF THE FAULT/GEOMETRIA DE LA FALLA:

LENGTH/LONGITUD: $136.5 \mathrm{~km}$ (136.7 km cumulative)

AVERAGE STRIKE/RUMBO PROMEDIO: $-37.0^{\circ} \pm 3^{\circ}\left(\mathrm{N} 37.0^{\circ} \mathrm{E} \pm 3^{\circ}\right)$

AVERAGE DIP/INCLINACION PROMEDIO: Unknown 
SENSE OF MOVEMENT/SENTIDO DE MOVIMIENTO: Reverse

Comments/Comentario: Vertical component is east-side up; may also have sinistral (left-lateral) motion.

GEOMORPHIC EXPRESSION/EXPRESION GEOMORFOLOGICA: Fault is marked by well preserved fault scarps, long straight traces, displaced drainages, and it forms aligned river courses.

RECURRENCE INTERVAL/INTERVALO DE RECURRENCIA: Unknown

SLIP RATE/TASA DE MOVIMIENTO: $<0.2 \mathrm{~mm} / \mathrm{yr}$

Comments/Comentario: Very low slip rate of $0.01-0.1 \mathrm{~mm} / \mathrm{yr}$ calculated on basis of displaced Quaternary morphologic features.

TIME OF MOST RECENT MOVEMENT/EDAD DEL ULTIMO MOVIMIENTO: Quaternary, <1.6 Ma

REFERENCES/REFERENCIAS

Asociación Colombiana de Ingeniería Sísmica (AIS) 1996, INGEOMINAS-Uniandes, Estudio general de la amenaza sísmica en Colombia: INGEOMINAS, Bogotá, 254 p.

Page, W.D., 1986, Seismic geology and seismicity of Northwestern Colombia: San Francisco, California, WoodwardClyde Consultants Report for ISA and Integral Ltda., Medellín, 200 p.

Taborda, B.A., 1965, Guidebook to the Geology of the De Mares Concession, Field Trip of Febuary 26-28, 1965: Colombian Soc. Petr. Geol. y Geoph., 25 p. (Bogotá).

\section{CO-22, MULATO-GETUDO FAULT}

FAULT NAME/NOMBRE DE LA FALLA: Mulato-Getudo

SYNOPSIS AND GEOLOGIC SETTING/SINOPSIS Y AMBIENTE GEOLOGICO: This fault extends along the eastern foot of the Cordillera Central where it marks the abrupt break in slope of the east-tilted Tertiary (Pre-Mesa) erosion surface of the Cordillera and the flat alluvial plains of the Magdalena Valley.

COMPILER, AFFILIATION, \& DATE OF COMPILATION/COMPILADOR, AFILIACION Y FECHA DE COMPILACION: Gabriel Paris, INGEOMINAS, Bogotá; November 1993. Reviewed January 1997 at CRQ and UNIQUINDIO, Armenia. Revised by Gabriel Paris, Estudios Geológico Mineros, Cali; June 1998.

TYPE OF STUDIES/TIPOS DE ESTUDIOS: Interpretation of aerial photographs, satellite imagery, and preliminary neotectonic studies.

GEOMETRY OF THE FAULT/GEOMETRIA DE LA FALLA:

LENGTH/LONGITUD: $187.3 \mathrm{~km}$ (188.8 km cumulative)

AVERAGE STRIKE/RUMBO PROMEDIO: $16.7^{\circ} \pm 9^{\circ}\left(\mathrm{N} 16.7^{\circ} \mathrm{E} \pm 9^{\circ}\right)$

AVERAGE DIP/INCLINACION PROMEDIO: High to medium angle to the west.

SENSE OF MOVEMENT/SENTIDO DE MOVIMIENTO: Reverse, sinistral (left lateral)

Comments/Comentarios: Vertical component is west-side up.

GEOMORPHIC EXPRESSION/EXPRESION GEOMORFOLOGICA: Forms a regional-scale degraded fault escarpment with an oustanding break in slope. Fault offsets Pliocene-Quaternary deposits and an extensive tilted erosional surface of probable Miocene to Pliocene age (pre-Mesa Formation, >1.5 Ma).

The northern half of the fault is characterized by aligned drainages and broad valleys.

RECURRENCE INTERVAL/INTERVALO DE RECURRENCIA: Unknown

SLIP RATE/TASA DE MOVIMIENTO: $<0.2 \mathrm{~mm} / \mathrm{yr}$ Comments/Comentarios: Very low slip rate of $0.01-0.1 \mathrm{~mm} / \mathrm{yr}$ based on displaced topographic features.

TIME OF MOST RECENT MOVEMENT/EDAD DEL ULTIMO MOVIMIENTO: Quaternary, <1.6 Ma Comments/Comentarios: Movement probably restricted to the early Quaternary (0.75-1.6 Ma).

REFERENCES/REFERENCIAS

Asociación Colombiana de Ingeniería Sísmica (AIS) 1996, INGEOMINAS—Uniandes, Estudio general de la amenaza sísmica en Colombia: INGEOMINAS, Bogotá, 254 p.

Page, W.D., 1986, Seismic geology and seismicity of Northwestern Colombia: San Francisco, California, WoodwardClyde Consultants Report for ISA and Integral Ltda., Medellín, 200 p.

Paris, G., y Romero, J., 1994, Fallas Activas en Colombia: INGEOMINAS, Boletin Geológico, v. 34, no. 2-3, p. 3-26 (Santafé de Bogotá).

Taborda, B.A., 1965, Guidebook to the Geology of the De Mares Concession, Field Trip of Febuary 26-28, 1965: Colombian Soc. Petr. Geol. y Geoph., 25 p. (Bogotá).

Vergara, H., 1989, Rasgos Neotectónicos en el Departamento del Tolima: INGEOMINAS, Boletin Geológico, v. 30 , no. 1, p. 21-42 (Santafé de Bogotá). 
Vergara, H., Paris, G., Taboada, A., Romero, y J., Castro, E., 1996, Actividad Neotectónica en las Fuentes Sismogénicas de la Región Central de Colombia: Memorias VII ( $7^{\text {th }}$ ) Congreso Colombiano de Geología, INGEOMINAS, Santafé de Bogotá, Colombia, 13 p.

Woodward-Clyde Consultants, 1980, Preliminary seismic hazard study, Stage A, Phase 1, San Carlos Proyect, Colombia: Report to Integral Ltda. and Interconexión Eléctrica S.A. (ISA), Bogotá, p. 9-77.

\section{CO-23, HONDA FAULT}

FAULT NUMBER/NUMERO DE LA FALLA: CO-23

FAULT NAME/NOMBRE DE LA FALLA: Honda

SYNOPSIS AND GEOLOGIC SETTING/SINOPSIS Y AMBIENTE GEOLOGICO: The Honda fault extends through the Middle Magdalena Valley, close to the Magdalena River and the cities of Ambalema, Honda, and La Dorada. It offsets beds of the Miocene Honda Formation, Pliocene Mesa Formation, and Quaternary sediment in alluvial terraces.

COMPILER, AFFILIATION, \& DATE OF COMPILATION/COMPILADOR, AFILIACION Y FECHA DE COMPILACION: Gabriel Paris, INGEOMINAS, Bogotá; November 1993. Reviewed January 1997 at CRQ and UNIQUINDIO, Armenia. Revised by Gabriel Paris, Estudios Geológico Mineros, Cali; June 1998.

TYPE OF STUDIES/TIPOS DE ESTUDIOS: Neotectonic field studies, and morphotectonic and microtectonics studies.

GEOMETRY OF THE FAULT/GEOMETRIA DE LA FALLA:

LENGTH/LONGITUD: $187.3 \mathrm{~km}$ (188.8 km cumulative)

AVERAGE STRIKE/RUMBO PROMEDIO: $16.6^{\circ} \pm 12^{\circ}\left(\mathrm{N} 16.6^{\circ} \mathrm{E} \pm 12^{\circ}\right)$

AVERAGE DIP/INCLINACION PROMEDIO: Unknown to the east

SENSE OF MOVEMENT/SENTIDO DE MOVIMIENTO: Reverse sinistral? (left lateral)

Comments/Comentarios: Vertical component is east-side up.

GEOMORPHIC EXPRESSION/EXPRESION GEOMORFOLOGICA: Characterized by continuous prominent scarps, aligned drainages, fault saddles, linear ridges and valleys, sag ponds, degraded scarps, and localized uplifts.

RECURRENCE INTERVAL/INTERVALO DE RECURRENCIA: Unknown

SLIP RATE/TASA DE MOVIMIENTO: $<1 \mathrm{~mm} / \mathrm{yr}$

Comments/Comentarios: Based on displaced geomorphic features and dated Quaternary terraces. The southern half of the fault has a very low to low slip rate $(<0.2 \mathrm{~mm} / \mathrm{yr})$; the northern half is low to medium (0.2 to $1 \mathrm{~mm} / \mathrm{yr}$ ).

TIME OF MOST RECENT MOVEMENT/EDAD DEL ULTIMO MOVIMIENTO: Holocene/post glacial, <15. k.y. Comments/Comentarios: Holocene terraces are offset by the fault.

REFERENCES/REFERENCIAS

Taborda, B.A., 1965, Guidebook to the Geology of the De Mares Concession, Field Trip of Febuary 26-28, 1965: Colombian Soc. Petr. Geol. y Geoph., 25 p. (Bogotá).

Vergara, H., 1989, Rasgos Neotectónicos en el Departamento del Tolima: INGEOMINAS, Boletin Geológico, v. 30, no. 1, p. 21-42 (Santafé de Bogotá).

Vergara, H., Paris, G., Taboada, A., Romero, y J., Castro, E., 1996, Actividad Neotectónica en las Fuentes Sismogénicas de la Región Central de Colombia: Memorias VII $\left(7^{\text {th }}\right)$ Congreso Colombiano de Geología, INGEOMINAS, Santafé de Bogotá, Colombia, $13 p$.

\section{CO-24, ALTO DEL TRIGO FAULT (PART OF SALINAS FAULT SYSTEM)}

FAULT NUMBER/NUMERO DE LA FALLA: CO-24

FAULT NAME/NOMBRE DE LA FALLA: Alto del Trigo (Salinas fault system)

SYNOPSIS AND GEOLOGIC SETTING/SINOPSIS Y AMBIENTE GEOLOGICO: The Alto del Trigo fault extends along the western slope of the Cordillera Oriental of Colombia, to the northwest of Santafé de Bogotá. It is part of the larger Salinas fault system. The fault places upper Cretaceous rocks on the east against Tertiary sedimentary rocks on the west. Synclines are developed on both sides of the fault suggesting oblique compression across the fault. Outcrops of faulted sedimentary rocks are common along the western slope of the Cordillera Oriental and middle part of the Magdalena Valley. 
COMPILER, AFFILIATION, \& DATE OF COMPILATION/COMPILADOR, AFILIACION Y FECHA DE COMPILACION: Gabriel Paris, INGEOMINAS, Bogotá; November 1993. Reviewed January 1997 at CRQ and UNIQUINDIO, Armenia. Revised by Gabriel Paris, Estudios Geológico Mineros, Cali; June 1998.

TYPE OF STUDIES/TIPOS DE ESTUDIOS: Reconnaisance field studies in neotectonics and morphotectonics.

GEOMETRY OF THE FAULT/GEOMETRIA DE LA FALLA:

LENGTH/LONGITUD: $114.9 \mathrm{~km}$ (117.6 km cumulative)

AVERAGE STRIKE/RUMBO PROMEDIO: $13.8^{\circ} \pm 12^{\circ}\left(\mathrm{N} 13.8^{\circ} \mathrm{E} \pm 12^{\circ}\right)$

Comments/Comentarios: The fault strike changes from NE to N-S to NW along length.

AVERAGE DIP/INCLINACION PROMEDIO: Moderate to high angle to east (?).

SENSE OF MOVEMENT/SENTIDO DE MOVIMIENTO: Reverse, probably sinistral (left lateral)

Comments/Comentarios: Vertical component is east-side up.

GEOMORPHIC EXPRESSION/EXPRESION GEOMORFOLOGICA: Fairly well defined fault line with old fault scarps, saddles, triangular facets, aligned drainages, and ponded (confined) alluvial deposits.

RECURRENCE INTERVAL/INTERVALO DE RECURRENCIA: 10 k.y. to 400 k.y.

SLIP RATE/TASA DE MOVIMIENTO: $<0.2 \mathrm{~mm} / \mathrm{yr}$

Comments/Comentarios: Slip rate of $0.01-0.1 \mathrm{~mm} / \mathrm{yr}$ estimated from amount of offset of neotectonic topographic features.

TIME OF MOST RECENT MOVEMENT/EDAD DEL ULTIMO MOVIMIENTO: Quaternary, $<1.6 \mathrm{Ma}$

REFERENCES/REFERENCIAS

Asociación Colombiana de Ingeniería Sísmica (AIS) 1996, INGEOMINAS—Uniandes, Estudio general de la amenaza sísmica en Colombia: INGEOMINAS, Bogotá, 254 p.

Vergara, H., Paris, G., Taboada, A., Romero, y J., Castro, E., 1996, Actividad Neotectónica en las Fuentes Sismogénicas de la Región Central de Colombia: Memorias VII $\left(7^{\text {h }}\right)$ Congreso Colombiano de Geología, INGEOMINAS, Santafé de Bogotá, Colombia, $13 p$.

\section{CO-25, BITUIMA FAULT (PART OF SALINAS FAULT SYSTEM)}

FAULT NUMBER/NUMERO DE LA FALLA: CO-25

FAULT NAME/NOMBRE DE LA FALLA: Bituima (part of Salinas fault system)

SYNOPSIS AND GEOLOGIC SETTING/SINOPSIS Y AMBIENTE GEOLOGICO: The Bituima fault extends through the western slope of the Cordillera Oriental of Colombia, west of Santafe de Bogotá and close to the towns of Utica and Bituima. The fault displaces sedimentary rocks of Tertiary, and upper and lower Cretaceous age. The fault very closely parallels the Alto del Trigo fault [CO-24], which is also part of the larger Salinas fault system.

COMPILER, AFFILIATION, \& DATE OF COMPILATION/COMPILADOR, AFILIACION Y FECHA DE COMPILACION: Gabriel Paris, INGEOMINAS, Bogotá; November, 1993. Revised by Gabriel Paris, Estudios Geológico Mineros, Cali; June 1998.

TYPE OF STUDIES/TIPOS DE ESTUDIOS: Reconnaissance geology, neotectonic, microtectonic and morphotectonic field studies.

GEOMETRY OF THE FAULT/GEOMETRIA DE LA FALLA:

LENGTH/LONGITUD: $179.5 \mathrm{~km}$ (186.3 km cumulative)

AVERAGE STRIKE/RUMBO PROMEDIO: $28.5^{\circ} \pm 17^{\circ}\left(\mathrm{N} 28.5^{\circ} \mathrm{E} \pm 17^{\circ}\right)$

Comments/Comentarios: Varies from about N-S to NE

AVERAGE DIP/INCLINACION PROMEDIO: Probably high to the east

SENSE OF MOVEMENT/SENTIDO DE MOVIMIENTO: Reverse, sinistral (left lateral)

Comments/Comentarios: Vertical component is east-side up.

GEOMORPHIC EXPRESSION/EXPRESION GEOMORFOLOGICA: Well developed Quaternary morphologic features such as ridges and fault-controlled streams.

RECURRENCE INTERVAL/INTERVALO DE RECURRENCIA: 3 k.y. to 30 k.y.

Comments/Comentarios: Calculated on basis of slip rate and probable moment magnitude of 6.3.

SLIP RATE/TASA DE MOVIMIENTO: $<0.2 \mathrm{~mm} / \mathrm{yr}$

Comments/Comentarios: Slip rate of 0.01-0.1 mm/yr estimated on basis of deformed morphological

features by the Asociación Colombiana de Ingeniería Sísmica (AIS), 1996. 
TIME OF MOST RECENT MOVEMENT/EDAD DEL ULTIMO MOVIMIENTO: Quaternary, $<1.6 \mathrm{Ma}$ Comments/Comentarios: Movement probably restricted to the early Quaternary (0.75-1.6 Ma). REFERENCES/REFERENCIAS

Asociación Colombiana de Ingeniería Sísmica (AIS), 1996, INGEOMINAS-Uniandes, Estudio general de la amenaza sísmica en Colombia: INGEOMINAS, Bogotá, $254 p$.

Vergara, H., Paris, G., Taboada, A., Romero, y J., Castro, E., 1996, Actividad Neotectónica en las Fuentes Sismogénicas de la Región Central de Colombia: Memorias VII (7th) Congreso Colombiano de Geología, INGEOMINAS, Santafé de Bogotá, Colombia, $13 p$.

\section{CO-26, SUAREZ FAULT}

FAULT NUMBER/NUMERO DE LA FALLA: CO-26

FAULT NAME/NOMBRE DE LA FALLA: Suarez

SYNOPSIS AND GEOLOGIC SETTING/SINOPSIS Y AMBIENTE GEOLOGICO: The Suarez fault joins the Bucaramanga fault [CO-02b] a few kilometers to the north of the city of Bucaramanga. The Suarez fault cuts Jurassic and Cretaceous sedimentary rocks, and Quaternary alluvial deposits and mudflows that form the "Bucaramanga Terrace".

COMPILER, AFFILIATION, \& DATE OF COMPILATION/COMPILADOR, AFILIACION Y FECHA DE COMPILACION: Gabriel Paris, INGEOMINAS, Cali; August, 1992. Revised by Gabriel Paris, Estudios Geológico Mineros, Cali; June 1998.

TYPE OF STUDIES/TIPOS DE ESTUDIOS: Interpretation of aerial photographs and general geologic field studies; reconnaissance microtectonic and morphotectonic studies.

GEOMETRY OF THE FAULT/GEOMETRIA DE LA FALLA:

LENGTH/LONGITUD: $98.3 \mathrm{~km}$ (98.7 km cumulative)

AVERAGE STRIKE/RUMBO PROMEDIO: $21.1^{\circ} \pm 8^{\circ}\left(\mathrm{N} 21.1^{\circ} \mathrm{E} \pm 8^{\circ}\right)$

AVERAGE DIP/INCLINACION PROMEDIO: $60^{\circ}-90^{\circ} \mathrm{W}$

SENSE OF MOVEMENT/SENTIDO DE MOVIMIENTO: Reverse sinistral (left lateral)

Comments/Comentarios: West-side up.

GEOMORPHIC EXPRESSION/EXPRESION GEOMORFOLOGICA: The trace of the fault is well defined, controls linear drainages such as the Suarez River for several kilometers, has sag ponds, and locally dams alluvium. The fault vertically offsets debris flows in the area of Giron and La Fuente and displaces a

Tertiary erosion surface.

RECURRENCE INTERVAL/INTERVALO DE RECURRENCIA:

SLIP RATE/TASA DE MOVIMIENTO: $<0.2 \mathrm{~mm} / \mathrm{yr}$

Comments/Comentarios: Slip rate of $0.1 \mathrm{~mm} / \mathrm{yr}$ is based on displaced Quaternary deposits.

TIME OF MOST RECENT MOVEMENT/EDAD DEL ULTIMO MOVIMIENTO: Quaternary, <1.6 Ma

REFERENCES/REFERENCIAS

Page, W.D., 1986, Seismic geology and seismicity of Northwestern Colombia: San Francisco, California, WoodwardClyde Consultants Report for ISA and Integral Ltda., Medellín, 200 p.

Paris, G., y Sarria, A., 1986, Proyecto Geofísico del Nordeste Colombiano-Neotectónica del Nororiente Colombiano: INGEOMINAS, Bogotá, Informe INGEOMINAS-ISA (Interconexión Eléctrica S.A.), 59 p.

Paris, G., y Romero, J., 1994, Fallas Activas en Colombia: INGEOMINAS, Boletin Geológico, v. 34, no. 2-3, p. 3-26 (Santafé de Bogotá).

Woodward-Clyde Consultants, 1982, Initial Seismic Hazards Evaluations, Fonce-Suarez Proyect, Colombia: San Francisco, California, Woodward-Clyde Consultants, unpublished report.

\section{CO-27, MORRONEGRO-LAS MERCEDES FAULT SYSTEM}

FAULT NUMBER/NUMERO DE LA FALLA: CO-27

FAULT NAME/NOMBRE DE LA FALLA: Morronegro-Las Mercedes (fault system) Comments/Comentarios: The central and northern part of this fault were mapped by Page (1986) as Las Mercedes fault; it is herein considered to be part of the larger Morronegro-Las Mercedes fault system.

SYNOPSIS AND GEOLOGIC SETTING/SINOPSIS Y AMBIENTE GEOLOGICO: Comprised of several faults in the northeast corner of the Colombian Cordillera Oriental. This is part of a broad zone of curved faults that change trend from NW to N and NE as they enter Venezuela. They are believed to be reverse faults in 
Colombia that are associated with the southwestward extension of the Boconó fault [VE-08] from

Venezuela into Colombia (see Audemard and others, 2000). The fault system displaces Paleozoic and

Cretaceous rocks. To the south of the town of Arboledas and between Arboledas and Cucutilla

(Santander del Norte) the faults seem to have Quaternary displacement (Page, 1986).

COMPILER, AFFILIATION, \& DATE OF COMPILATION/COMPILADOR, AFILIACION Y FECHA DE

COMPILACION: Gabriel Paris, INGEOMINAS, Bogotá; November 1993. Reviewed January 1997 at CRQ and UNIQUINDIO, Armenia. Revised by Gabriel Paris, Estudios Geológico Mineros, Cali; June 1998 and Departamento de Geografia, Univalle, Cali, December 1999.

TYPE OF STUDIES/TIPOS DE ESTUDIOS: Interpretation of aerial photographs and general geologic field studies; preliminary microtectonic and morphotectonic studies.

GEOMETRY OF THE FAULT/GEOMETRIA DE LA FALLA:

LENGTH/LONGITUD: $204.3 \mathrm{~km}$ (214.7 km cumulative)

AVERAGE STRIKE/RUMBO PROMEDIO: $-20.3^{\circ} \pm 17^{\circ}\left(\mathrm{N} 20.3^{\circ} \mathrm{W} \pm 17^{\circ}\right)$

AVERAGE DIP/INCLINACION PROMEDIO: Various

Comments/Comentarios: Strike varies from NW in the south, to N-S and NE in the northern part where it bends towards the Boconó fault [VE-06] of Venezuela (see Audemard and others, 2000).

SENSE OF MOVEMENT/SENTIDO DE MOVIMIENTO: Reverse, strike slip.

Comments/Comentarios: Vertical component is west-side up in the north and east-side up in the south. Movement is sinistral (left lateral) at the southern end and dextral (right lateral) in the northern part.

GEOMORPHIC EXPRESSION/EXPRESION GEOMORFOLOGICA: Characteristic expression includes fault saddles, sag ponds, aligned and offset hills, faulting and folding of Quaternary beds. Overall, the fault has a prominent set of aligned geomorphic features. Ridgelines with sinistral offset are found near Pamplona and offset hills near Bochalema. In addition, there is a striking change in regional slope on both sides of the fault system.

RECURRENCE INTERVAL/INTERVALO DE RECURRENCIA: Unknown

SLIP RATE/TASA DE MOVIMIENTO: 0.2-1.0 mm/yr

Comments/Comentarios: Low to moderate rate estimated on basis of offset of deformed Quaternary geomorphic features (Page, 1986).

TIME OF MOST RECENT MOVEMENT/EDAD DEL ULTIMO MOVIMIENTO: Quaternary $<1.6 \mathrm{Ma}$ REFERENCES/REFERENCIAS

Audemard, F.A., Machette, M.N., Dart, R.L., and Haller, K.M., 2000, Map and Database of Quaternary Faults in Venezuela and its Offshore Regions: U.S. Geological Survey Open-File Report 00-018, 76 p., 1 plate $(1: 2,000,000$ scale).

Page, W.D., 1986, Seismic geology and seismicity of Northwestern Colombia: San Francisco, California, WoodwardClyde Consultant Report for ISA and Integral Ltda., Medellín, 200 p.

Paris, G., y Sarria, A., 1986, Proyecto Geofísico del Nordeste Colombiano-Neotectónica del Nororiente Colombiano: INGEOMINAS, Bogotá, Informe INGEOMINAS-ISA (Interconexión Eléctrica S.A.), 59 p.

Paris, G., y Romero, J., 1994, Fallas Activas en Colombia: INGEOMINAS, Boletin Geológico, v. 34, no. 2-3, p. 3-26 (Santafé de Bogotá).

\section{CO-28, CHITAGA-PAMPLONA FAULTS}

FAULT NUMBER/NUMERO DE LA FALLA: CO-28

FAULT NAME/NOMBRE DE LA FALLA: Chitaga-Pamplona

SYNOPSIS AND GEOLOGIC SETTING/SINOPSIS Y AMBIENTE GEOLOGICO: This set of faults parallels the Morronegro fault [CO-27]. The Chitaga-Pamplona fault places Paleozoic rocks (on the west) against Tertiary and Cretaceous rocks (on the east). The structural behavior of the fault is very similar to faults of the Morronegro-Las Mercedes fault system [CO-27]. Both faults [CO-27 and CO-28] are believed to be an extension of the Bocono fault [VE-06] and associated faults of the Venezuelan Andes (see Audemard and others, 2000) and are shown thus on the map.

COMPILER, AFFILIATION, \& DATE OF COMPILATION/COMPILADOR, AFILIACION Y FECHA DE COMPILACION: Gabriel Paris, INGEOMINAS, Bogotá; November 1993. Reviewed January 1997 at CRQ and UNIQUINDIO, Armenia. Revised by Gabriel Paris, Estudios Geológico Mineros, Cali, June 1998, and Departamento de Geografía Univalle, Cali, December 1999. 
TYPE OF STUDIES/TIPOS DE ESTUDIOS: Reconnaissance field and morphotectonic studies.

GEOMETRY OF THE FAULT/GEOMETRIA DE LA FALLA:

LENGTH/LONGITUD: $192.5 \mathrm{~km}$ (354.3 km cumulative)

AVERAGE STRIKE/RUMBO PROMEDIO: $-4.8^{\circ} \pm 30^{\circ}\left(\mathrm{N} 4.8^{\circ} \mathrm{W} \pm 30^{\circ}\right)$

Comments/Comentarios: Strike varies from $\mathrm{N} 45^{\circ} \mathrm{W}$ to $\mathrm{N} 30-45^{\circ} \mathrm{E}$

AVERAGE DIP/INCLINACION PROMEDIO: Variable to the east and west

SENSE OF MOVEMENT/SENTIDO DE MOVIMIENTO: Reverse and sinistral, with northern side west-side up and southern side east-side up

GEOMORPHIC EXPRESSION/EXPRESION GEOMORFOLOGICA: Well expressed but local neotectonic

geomorphic features such as sag ponds, fault scarps, and abrupt changes in slope on both sides of fault.

RECURRENCE INTERVAL/INTERVALO DE RECURRENCIA: Unknown

SLIP RATE/TASA DE MOVIMIENTO: Unknown, probably 0.2-1 mm/yr.

TIME OF MOST RECENT MOVEMENT/EDAD DEL ULTIMO MOVIMIENTO: Quaternary <1.6 Ma

Comments/Comentarios: Certainly Quaternary, and probably early Quaternary (750 ka-1.6 Ma). However, no young Quaternary deposits were observed or reported as offset.

REFERENCES/REFERENCIAS

Audemard, F.A., Machette, M.N., Dart, R.L., and Haller, K.M., 2000, Map and Database of Quaternary Faults in Venezuela and its Offshore Regions: U.S. Geological Survey Open-File Report 00-018, 76 p., 1 plate $(1: 2,000,000$ scale).

Page, W.D., 1986, Seismic geology and seismicity of Northwestern Colombia: San Francisco, California, WoodwardClyde Consultants Report for ISA and Integral Ltda., Medellín, 200 p.

Paris, G., y Sarria, A., 1986, Proyecto Geofísico del Nordeste Colombiano-Neotectónica del Nororiente Colombiano: INGEOMINAS, Bogotá, Informe INGEOMINAS-ISA (Interconexión Eléctrica S.A.), 59 p.

Paris, G., y Romero, J., 1994, Fallas Activas en Colombia: INGEOMINAS, Boletin Geológico, v. 34, no. 2-3, p. 3-26 (Santafé de Bogotá).

\section{CO-29, EASTERN FRONTAL FAULT SYSTEM}

FAULT NUMBER/NUMERO DE LA FALLA: CO-29

FAULT NAME/NOMBRE DE LA FALLA: Eastern Frontal fault system

Comments/Comentarios: The Eastern Frontal fault system is one of the most active and continuous fault systems in Colombia. Several names have been given to it according to where it has been studied along its length. Local common fault names or "sections" from north to south are the Guaicaramo, Yopal, San José, Servitá-Santa Maria, Guayuriba, Algeciras, Mocoa, Florencia and Afiladores. Other less common names include the Pajarito, Colepato, Acacias, and Colonia. The fault system is probably an extension of the Bocono fault [VE-06] and associated faults of the Venezuelan Andes and likely continues south as a dextral fault [EC-29a] in the Republic of Ecuador. The faults of the Eastern Frontal system are named and numbered as separate sections until futher research and field work is done on them.

SYNOPSIS AND GEOLOGIC SETTING/SINOPSIS Y AMBIENTE GEOLOGICO: The Eastern Frontal fault system is the main fault system bounding the Andean Ranges (in the east) and the lowlands or "Los Llanos Orientales" plains in the east. This fault system is the southern continuation of the Bocono Fault in Venezuela and extends all the way south to the Jambali Graben in the gulf of Guayaquil in Ecuador. It is considered by some authors to be the actual plate boundary of the South American Plate disconnecting it from the North Andes Block (Aggarwal, 1983) The Eastern Frontal fault system extends from near latitude $3^{\circ} \mathrm{N}$, north into the Venezuelan Andes, close to San Cristobal at about latitude $7.5^{\circ} \mathrm{N}$. The Eastern Frontal fault system developed from an initial set of distensional parallel fractures that dipped westward and which formed the eastern border of a huge Paleozoic to Cretaceous sedimentary basin. Later in the Neogene, regional uplift and shortening of the crust gave rise to the Cordillera Oriental of Colombia. The initial normal faults reversed motion and became thrust faults in the "Borde Llanero". The "Guaicaramo" fault [South Guaicaramo section, CO-29c] deforms late Neogene deposits and is characterized by neotectonic morphology that is some of the most outstanding and continuous in the country.

COMPILER, AFFILIATION, \& DATE OF COMPILATION/COMPILADOR, AFILIACION Y FECHA DE COMPILACION: Gabriel Paris, INGEOMINAS, Bogotá; November 1993. Reviewed January 1997 at CRQ and UNIQUINDIO, Armenia. Revised by Gabriel Paris, Estudios Geológico Mineros, Cali; June 1998. 
TYPE OF STUDIES/TIPOS DE ESTUDIOS: Interpretation of aerial photographs, field studies in neotectonics, morphotectonics, and microtectonics.

GEOMETRY OF THE FAULT/GEOMETRIA DE LA FALLA:

LENGTH/LONGITUD: $921.4 \mathrm{~km}$ (1821.8 km cumulative)

AVERAGE STRIKE/RUMBO PROMEDIO: $42.1^{\circ} \pm 19^{\circ}\left(\mathrm{N} 42.1^{\circ} \mathrm{E} \pm 19^{\circ}\right)$

AVERAGE DIP/INCLINACION PROMEDIO: $30-40^{\circ}$ to the west

Comments/comentarios: The fault dip is much flatter at its northern end, steeping gradually to the south

where it may attain near vertical dips with pure strike-slip displacement.

SENSE OF MOVEMENT/SENTIDO DE MOVIMIENTO: Reverse, dextral (right lateral), west-side up.

NUMBER OF SECTIONS/NUMERO DE SECCIONES: 10

Comments/Comentarios: This long complex fault system is informally divided into ten sections. The name Guaicaramo is used for three fault sections (north, central and south) close to the region so named. The other sections are named after localities near each section.

REFERENCES/REFERENCIAS

Aggarwal, Y., 1983, Seismic slip rates and earthquakes ruptures zones in the southern Caribbean-Implications for plate motions and earthquake hazard in this region (abstract): Abstracts $10^{\text {th }}$ Caribb. Geol. Conf., $16 \mathrm{p}$.

\section{CO-29A, NORTHERN GUAICARAMO SECTION, EASTERN FRONTAL FAULT SYSTEM}

SECTION NUMBER/NUMERO DE LA SECCION: CO-29a

SECTION NAME/NOMBRE DE LA SECCION: Northern Guaicaramo

GEOMETRY OF THE SECTION/GEOMETRIA DE LA SECCION:

LENGTH/LONGITUD: $145.5 \mathrm{~km}$ (167.2 km cumulative)

AVERAGE STRIKE/RUMBO PROMEDIO: $19.5^{\circ} \pm 20^{\circ}\left(\mathrm{N} 19.5^{\circ} \mathrm{E} \pm 20^{\circ}\right)$

AVERAGE DIP/INCLINACION PROMEDIO: $30-35^{\circ}$ to the west

Comments/Comentarios: Attitude estimated from geomorphic features by AIS (1996).

SENSE OF MOVEMENT/SENTIDO DE MOVIMIENTO: Reverse, dextral (right-lateral)

Comments/Comentarios: West-side up.

GEOMORPHIC EXPRESSION/EXPRESION GEOMORFOLOGICA: Prominent fault trace as observed in satellite images. Trace is marked by well developed scarps on Tertiary formations and young fault scarps on Quaternary mudflows and alluvial fan deposits. The morphology of the fault includes saddles, aligned drainages, offset drainages, and tilted and folded sequences of stream terraces.

RECURRENCE INTERVAL/INTERVALO DE RECURRENCIA: Unknown

SLIP RATE/TASA DE MOVIMIENTO: $1-5 \mathrm{~mm} / \mathrm{yr}$

Comments/Comentarios: Based on offset of Quaternary alluvial terraces and other landforms.

TIME OF MOST RECENT MOVEMENT/EDAD DEL ULTIMO MOVIMIENTO: Holocene/post glacial, $<15 \mathrm{ka}$ Comments/Comentarios: Quaternary alluvial terraces and other landforms are disrupted. Holocene displacement is fairly certain from geomorphology.

REFERENCES/REFERENCIAS

Asociación Colombiana de Ingeniería Sísmica (AIS) 1996, INGEOMINAS-Uniandes, Estudio general de la amenaza sísmica en Colombia: INGEOMINAS, Bogotá, 254 p.

Page, W.D., 1986, Seismic geology and seismicity of Northwestern Colombia: San Francisco, California, WoodwardClyde Consultants Report for ISA and Integral Ltda., Medellín, 200 p.

Paris, G., y Sarria, A., 1986, Proyecto Geofísico del Nordeste Colombiano-Neotectónica del Nororiente Colombiano: INGEOMINAS, Bogotá, Informe INGEOMINAS-ISA (Interconexión Eléctrica S.A.), 59 p.

Paris, G., y Romero, J., 1994, Fallas Activas en Colombia: INGEOMINAS, Boletin Geológico, v. 34, no. 2-3, p. 3-26 (Santafé de Bogotá).

Vergara, H., Paris, G., Taboada, A., Romero, y J., Castro, E., 1996, Neotectónica del Borde Llanero—Resultados preliminares. Memorias del Seminario de Sismotectónica del Borde Llanero Colombiano, INGEOMINAS, Medellín, $13 p$.

CO-29B, CENTRAL GUAICARAMO SECTION, EASTERN FRONTAL FAULT SYSTEM

SECTION NUMBER/NUMERO DE LA SECCION: CO-29b

SECTION NAME/NOMBRE DE LA SECCION: Central Guaicaramo 
GEOMETRY OF THE SECTION/GEOMETRIA DE LA SECCION:

LENGTH/LONGITUD: $121.9 \mathrm{~km}$ (123.8 km cumulative)

AVERAGE STRIKE/RUMBO PROMEDIO: $25.9^{\circ} \pm 17^{\circ}\left(\mathrm{N} 25.9^{\circ} \mathrm{E} \pm 17^{\circ}\right)$

AVERAGE DIP/INCLINACION PROMEDIO: $30-35^{\circ} \mathrm{W}$

Comments/Comentarios: Dip estimated from outcrops by AIS (1996).

SENSE OF MOVEMENT/SENTIDO DE MOVIMIENTO: Reverse dextral (right-lateral)

GEOMORPHIC EXPRESSION/EXPRESION GEOMORFOLOGICA: Outstanding topographic fault trace marked by Quaternary fault scarps, saddles, ponded Quaternary alluvium, aligned and offset drainages, drainages reversed and beheading and tilted and folded stream terraces.

RECURRENCE INTERVAL/INTERVALO DE RECURRENCIA: Unknown

SLIP RATE/TASA DE MOVIMIENTO: $1-5 \mathrm{~mm} / \mathrm{yr}$

Comments/Comentarios: A high rate was calculated from offset Quaternary deposits. Average values for slip rate are close to $2.0 \mathrm{~mm} / \mathrm{yr}$. This is the one of the fastest moving faults in eastern Colombia.

TIME OF MOST RECENT MOVEMENT/EDAD DEL ULTIMO MOVIMIENTO: Historic (1995)

Comments/Comentarios: No surface rupture was identified. See discussion below.

NAME OF EARTHQUAKE/NOMBRE DEL TERREMOTO: Tauramena

DATE/FECHA: 01/19/95, Time 20:47:39.9

MAGNITUDE OR INTENSITY/MAGNITUD O INTENSIDAD: M 6.5, lo VII in epicenter Comments/Comentarios: The epicenter was located in the very southern part of the central Guaicaramo section, but near the southern Guaicaramo section; location may have been at boundary between the two sections.

REFERENCES/REFERENCIAS

Page, W.D., 1986, Seismic geology and seismicity of Northwestern Colombia: San Francisco, California, WoodwardClyde Consultants Report for ISA and Integral Ltda., Medellín, 200 p.

Paris, G., y Romero, J., 1994, Fallas Activas en Colombia: INGEOMINAS, Boletin Geológico, v. 34, no. 2-3, p. 3-26 (Santafé de Bogotá).

Vergara, H., Paris, G., Taboada, A., Romero, y J., Castro, E., 1996, Actividad Neotectónica en las Fuentes Sismogénicas de la Región Central de Colombia: Memorias VII ( $\left.7^{\text {th }}\right)$ Congreso Colombiano de Geología, INGEOMINAS, Santafé de Bogotá, Colombia, $13 \mathrm{p}$.

Vergara, H., Paris, G., Taboada, A., Romero, y J., Castro, E., 1996, Neotectónica del Borde Llanero-Resultados preliminares. Memorias del Seminario de Sismotectónica del Borde Llanero Colombiano, INGEOMINAS, Medellín, $13 p$.

\section{CO-29C, SOUTHERN GUAICARAMO SECTION, EASTERN FRONTAL FAULT SYSTEM}

SECTION NUMBER/NUMERO DE LA SECCION: CO-29c

SECTION NAME/NOMBRE DE LA SECCION: Southern Guaicaramo

Comments/Comentarios: This was named the Guaicaramo fault by Page (1986) and very closely parallels the Cumaral fault (San Pedro-Cumaral section [CO-29e]) to the east.

GEOMETRY OF THE SECTION/GEOMETRIA DE LA SECCION:

LENGTH/LONGITUD: $75.9 \mathrm{~km}$ (130.6 km cumulative)

AVERAGE STRIKE/RUMBO PROMEDIO: $45.6^{\circ} \pm 9^{\circ}\left(\mathrm{N} 45.6^{\circ} \mathrm{E} \pm 9^{\circ}\right)$

AVERAGE DIP/INCLINACION PROMEDIO: $30-35^{\circ} \mathrm{W}$

Comments/Comentarios: Dip measured from outcrops of sheared rocks by AIS (1996).

SENSE OF MOVEMENT/SENTIDO DE MOVIMIENTO: Reverse, dextral (right lateral)

GEOMORPHIC EXPRESSION/EXPRESION GEOMORFOLOGICA: Trace characterized by well defined fault scarps, saddles, and offset Quaternary alluvial fans. A prominent fault trace bounds the Serrania de Las Palomas on the east.

RECURRENCE INTERVAL/INTERVALO DE RECURRENCIA: 2-20 k.y. Comments/Comentarios: Calculation from slip rate and probable magnitude values.

SLIP RATE/TASA DE MOVIMIENTO: 1-5 mm/yr Comments/Comentarios: Calculated from deformed and offset Holocene features.

TIME OF MOST RECENT MOVEMENT/EDAD DEL ULTIMO MOVIMIENTO: Holocene/post glacial, <15 ka(?) Comments/Comentarios: Quaternary alluvial fans and other landforms are disrupted. Holocene displacement is fairly certain from geomorphology. 


\section{REFERENCES/REFERENCIAS}

Asociación Colombiana de Ingeniería Sísmica (AIS) 1996, INGEOMINAS-Uniandes, Estudio general de la amenaza sísmica en Colombia: INGEOMINAS, Bogotá, 254 p.

Page, W.D., 1986, Seismic geology and seismicity of Northwestern Colombia: San Francisco, California, WoodwardClyde Consultants Report for ISA and Integral Ltda., Medellín, $200 \mathrm{p}$.

Paris, G., y Romero, J., 1994, Fallas Activas en Colombia: INGEOMINAS, Boletin Geológico, v. 34, no. 2-3, p. 3-26 (Santafé de Bogotá).

Vergara, H., Paris, G., Taboada, A., Romero, y J., Castro, E., 1996, Actividad Neotectónica en las Fuentes Sismogénicas de la Región Central de Colombia: Memorias VII ( $\left.7^{\text {th }}\right)$ Congreso Colombiano de Geología, INGEOMINAS, Santafé de Bogotá, Colombia, 13 p.

Vergara, H., Paris, G., Taboada, A., Romero, y J., Castro, E., 1996, Neotectónica del Borde Llanero-Resultados preliminares. Memorias del Seminario de Sismotectónica del Borde Llanero Colombiano, INGEOMINAS, Medellín, $13 p$.

Woodward-Clyde Consultants, 1982, Preliminary evaluation of seismic hazards and of erosion and sediment sources (geomorphology), Rio Negro-Guayuriba Proyect, Colombia: Report to Gomez Cajiao y Asociados Cia Ltda y la Empresa de Energía de Bogotá, 43p.

\section{CO-29D, YOPAL (FAULT) SECTION, EASTERN FRONTAL FAULT SYSTEM}

SECTION NUMBER/NUMERO DE LA SECCION: CO-29d

SECTION NAME/NOMBRE DE LA SECCION: Yopal (fault)

SYNOPSIS AND GEOLOGIC SETTING/SINOPSIS Y AMBIENTE GEOLOGICO: The Yopal fault is the easternmost active geologic thrust fault known in northeastern Colombia. North of the city of Yopal, it places Neogene rocks on the west against Quaternary alluvial deposits (or "Los Llanos" plains) on the east.

COMPILER, AFFILIATION, \& DATE OF COMPILATION/COMPILADOR, AFILIACION Y FECHA DE COMPILACION: Gabriel Paris, Estudios Geológico Mineros, Cali; June 1998.

TYPE OF STUDIES/TIPOS DE ESTUDIOS: Reconnaissance morphotectonic and neotectonic field studies. GEOMETRY OF THE SECTION/GEOMETRIA DE LA SECCION:

LENGTH/LONGITUD: $220.0 \mathrm{~km}$ (232.0 km cumulative)

AVERAGE STRIKE/RUMBO PROMEDIO: $26.9^{\circ} \pm 21^{\circ}\left(\mathrm{N} 26.9^{\circ} \mathrm{E} \pm 21^{\circ}\right)$

Comments/Comentarios: Strike varies from N-S to NE.

AVERAGE DIP/INCLINACION PROMEDIO: $20^{\circ}-30^{\circ} \mathrm{W}$

SENSE OF MOVEMENT/SENTIDO DE MOVIMIENTO: Reverse, dextral (right-lateral)

GEOMORPHIC EXPRESSION/EXPRESION GEOMORFOLOGICA: Characterized by scarps with consistent height (10-15 m) for long distances; a few scarps are as much as $60 \mathrm{~m}$ high. Faulting has formed superposed terraces with different angles of deposition, tilted terraces and gouge zones in Quaternary deposits. In addition, there are open folds in Pliocene-Quaternary sediments and thrusting of Tertiary beds over Quaternary terraces. Streams show a consistent pattern of narrowing from the west side to the east side of fault traces. Defeated, beheaded and reversed streams are common to the north of Yopal. There is abundant evidence for displacement of Quaternary unconsolidated deposits (Page, 1986).

RECURRENCE INTERVAL/INTERVALO DE RECURRENCIA: Unknown

SLIP RATE/TASA DE MOVIMIENTO: $1-5 \mathrm{~mm} / \mathrm{yr}$

Comments/Comentarios: High slip rate calculated from height of scarps on Quaternary mudflows and alluvial fans of late Quaternary age.

TIME OF MOST RECENT MOVEMENT/EDAD DEL ULTIMO MOVIMIENTO: Holocene/post glacial, $<15 \mathrm{ka}$ Comments/Comentarios: Movement probably as young as late Holocene.

REFERENCES/REFERENCIAS

Page, W.D., 1986, Seismic geology and seismicity of Northwestern Colombia: San Francisco, California, WoodwardClyde Consultants Report for ISA and Integral Ltda., Medellín, 200 p. 


\section{CO-29E, SAN PEDRO-CUMARAL (FAULT) SECTION, EASTERN FRONTAL FAULT SYSTEM}

SECTION NUMBER/NUMERO DE LA SECCION: CO-29e

SECTION NAME/NOMBRE DE LA SECCION: San Pedro-Cumaral (fault)

Comments/Cometarios: The Cumaral fault is located close to and west of the San Pedro fault. Together they form the San Pedro-Cumaral section.

GEOMETRY OF THE SECTION/GEOMETRIA DE LA SECCION:

LENGTH/LONGITUD: $69.7 \mathrm{~km}$ (136.8 km cumulative)

AVERAGE STRIKE/RUMBO PROMEDIO: $37.5^{\circ} \pm 6^{\circ}\left(\mathrm{N} 37.5^{\circ} \mathrm{E} \pm 6^{\circ}\right)$

AVERAGE DIP/INCLINACION PROMEDIO: $20-30^{\circ} \mathrm{W}$

SENSE OF MOVEMENT/SENTIDO DE MOVIMIENTO: Reverse, slightly dextral (right lateral)

GEOMORPHIC EXPRESSION/EXPRESION GEOMORFOLOGICA: Well defined fault scarps on Tertiary and

Quaternary sedimentary rocks that form hilly landscapes, upwarping and tilting of terraces, deflected

streams, linear fault ridges, and narrowing of sreams on east sides of the fault.

RECURRENCE INTERVAL/INTERVALO DE RECURRENCIA: Unknown

SLIP RATE/TASA DE MOVIMIENTO: $1-5 \mathrm{~mm} / \mathrm{yr}$

Comments/Comentarios: High rate calculated on basis of offset alluvial gravels that have no visible rims of alteration in pebbles. Gravels are probably of Holocene age.

TIME OF MOST RECENT MOVEMENT/EDAD DEL ULTIMO MOVIMIENTO: Holocene/post glacial, $<15 \mathrm{ka}$ REFERENCES/REFERENCIAS

Asociación Colombiana de Ingeniería Sísmica (AIS) 1996, INGEOMINAS-Uniandes, Estudio general de la amenaza sísmica en Colombia: INGEOMINAS, Bogotá, 254 p.

Paris, G., y Sarria, A., 1986, Proyecto Geofísico del Nordeste Colombiano-Neotectónica del Nororiente Colombiano: INGEOMINAS, Bogotá, Informe INGEOMINAS-ISA (Interconexión Eléctrica S.A.), 59 p.

Vergara, H., Paris, G., Taboada, A., Romero, y J., Castro, E., 1996, Actividad Neotectónica en las Fuentes Sismogénicas de la Región Central de Colombia: Memorias VII ( $\left.7^{\text {th }}\right)$ Congreso Colombiano de Geología, INGEOMINAS, Santafé de Bogotá, Colombia, $13 p$.

\section{CO-29F, SERVITA-SANTA MARIA (FAULT GROUP) SECTION, EASTERN FRONTAL FAULT SYSTEM}

SECTION NUMBER/NUMERO DE LA SECCION: CO-29f

SECTION NAME/NOMBRE DE LA SECCION: Servita-Santa Maria (fault group)

SYNOPSIS AND GEOLOGIC SETTING/SINOPSIS Y AMBIENTE GEOLOGICO: The Servita-Santa Maria group of faults extends close to the east margin of the Eastern Colombian Range near the Guaicaramo fault system, east of Santafe de Bogotá. These faults are grouped in a system for practical purposes because of their morphologic similarity, geometric characteristics and Quaternary activity and includes the Servita fault to the south and Santa Maria and San Pedro de Jagua faults to the north. Thrusting of Paleozoic rocks over younger formations is seen along faults of this group. The faults offset Jurassic, Cretaceous and Tertiary strata and deform Quaternary strata.

COMPILER, AFFILIATION, \& DATE OF COMPILATION/COMPILADOR, AFILIACION Y FECHA DE COMPILACION: Gabriel Paris, INGEOMINAS, Bogotá; August, 1993. Revised by Gabriel Paris, Estudios Geológico Mineros, Cali; June 1998; Departamento de Geografía, Universidad del Valle, December 1999.

TYPE OF STUDIES/TIPOS DE ESTUDIOS: Interpretation of aerial photographs, morphotectonics, and reconnaissance neotectonic field studies. This fault system deserves more detailed neotectonic studies in order to be better understood.

GEOMETRY OF THE SECTION/GEOMETRIA DE LA SECCION:

LENGTH/LONGITUD: $295.8 \mathrm{~km}$ (509.8 km cumulative)

AVERAGE STRIKE/RUMBO PROMEDIO: $42.3^{\circ} \pm 15^{\circ}\left(\mathrm{N} 42.3^{\circ} \mathrm{E} \pm 15^{\circ}\right)$

AVERAGE DIP/INCLINACION PROMEDIO: $30^{\circ}-45^{\circ} \mathrm{W}$

Comments/Comentarios: Estimated by AIS (1997) from geomorphic expression and general attitude of beds. 
SENSE OF MOVEMENT/SENTIDO DE MOVIMIENTO: Reverse, dextral(?) (right lateral?)

Comments/Comentarios: The vertical component is west-side up.

GEOMORPHIC EXPRESSION/EXPRESION GEOMORFOLOGICA: Strong change in slope between hard

Paleozoic rocks on the west and soft Cretaceous and Tertiary rock and Quaternary sediments on the east. Fault trace characterized by breaks in slope, upwarping of Quaternary deposits, prominent fault scarps on unconsolidated sediments, offset colluvium and alluvial terrace sediment, offset streams, saddles, aligned river valleys, and linear fault ridges. Displacement in late Quaternary is very large

(Page, 1986), but unstated.

RECURRENCE INTERVAL/INTERVALO DE RECURRENCIA: Unknown

Comments/Comentarios: Maximum moment magnitude of 7.6 is calculated assuming a total rupture of the faults length.

SLIP RATE/TASA DE MOVIMIENTO: $1-5 \mathrm{~mm} / \mathrm{yr}$

Comments/Comentarios: A slip rate is $1-2 \mathrm{~mm} / \mathrm{yr}$ was determined from measurements of deformed Quaternary alluvial gravel deposits along the Servita fault trace (AIS, 1996). Lower slip rates (0.2-1 mm/yr) are shown for the multiple thrust strands at the faults northern end.

TIME OF MOST RECENT MOVEMENT/EDAD DEL ULTIMO MOVIMIENTO: Quaternary, <1.6 Ma Comments/Comentarios: If the above slip rate is correct, the most recent movement is possibly $<15 \mathrm{ka}$.

REFERENCES/REFERENCIAS

Asociación Colombiana de Ingeniería Sísmica (AIS) 1996, INGEOMINAS—Uniandes, Estudio general de la amenaza sísmica en Colombia: INGEOMINAS, Bogotá, 254 p.

Page, W.D., 1986, Seismic geology and seismicity of Northwestern Colombia: San Francisco, California, WoodwardClyde Consultants Report for ISA and Integral Ltda., Medellín, 200 p.

Vergara, H., Paris, G., Taboada, A., Romero, Y J., Castro, E., 1996, Actividad Neotectónica En Las Fuentes Sismogénicas De La Región Central De Colombia: Memorias Vii $\left(7^{\text {th }}\right)$ Congreso Colombiano De Geología, INGEOMINAS, Santafé De Bogotá, Colombia, $13 \mathrm{Pp}$.

Woodward-Clyde Consultants, 1982, Preliminary evaluation of seismic hazards and of erosion and sediment sources (geomorphology), Rio Negro-Guayuriba Proyect, Colombia: Report to Gomez Cajiao y Asociados Cia Ltda y la Empresa de Energía de Bogotá, 43p.

\section{CO-29G, GUAYURIBA (FAULT) SECTION, EASTERN FRONTAL FAULT SYSTEM}

SECTION NUMBER/NUMERO DE LA SECCION: CO-29g

SECTION NAME/NOMBRE DE LA SECCION: Guayuriba (fault)

SYNOPSIS AND GEOLOGIC SETTING/SINOPSIS Y AMBIENTE GEOLOGICO: The Guayuriba fault is located to the southeast the Servitá-Santa Maria section [CO-29f]. It lies south of and close to the city of

Villavicencio, at the base of the eastern front of the Cordillera Oriental of Colombia, and extends along the change of slope between the uplifted Cordillera and the flat plains of Los Llanos.

COMPILER, AFFILIATION, \& DATE OF COMPILATION/COMPILADOR, AFILIACION Y FECHA DE COMPILACION: Gabriel Paris, Estudios Geológico Mineros, Cali; June 1998; Departamento de Geografía Universidad del Valle, Cali, December 1999.

TYPE OF STUDIES/TIPOS DE ESTUDIOS: Reconnaissance neotectonic field studies, as well as morphotectonics, and microtectonics.

GEOMETRY OF THE SECTION/GEOMETRIA DE LA SECCION:

LENGTH/LONGITUD: $131.0 \mathrm{~km}$ (142.3 km cumulative)

AVERAGE STRIKE/RUMBO PROMEDIO: $40.7^{\circ} \pm 25^{\circ}\left(\mathrm{N} 40.7^{\circ} \mathrm{E} \pm 25^{\circ}\right)$

AVERAGE DIP/INCLINACION PROMEDIO: $30^{\circ}-40^{\circ} \mathrm{W}$

SENSE OF MOVEMENT/SENTIDO DE MOVIMIENTO: Reverse, dextral (right lateral)

GEOMORPHIC EXPRESSION/EXPRESION GEOMORFOLOGICA: Trace characterized by continuous fault scarp, beheaded streams, upwarping, strong breaks in slope, fault saddles, aligned and offset drainages, and formation of stair-like drainages.

RECURRENCE INTERVAL/INTERVALO DE RECURRENCIA: 700 yrs

Comments/Comentarios: Estimated from slip rate and a maximum moment magnitude of 7.0 based on total rupture of this fault. 
SLIP RATE/TASA DE MOVIMIENTO: $1-5 \mathrm{~mm} / \mathrm{yr}$

Comments/Comentarios: High rate calculated from offset gravel pebbles showing no alteration rims.

Gravels are probably of Holocene age.

TIME OF MOST RECENT MOVEMENT/EDAD DEL ULTIMO MOVIMIENTO: Quaternary, $<1.6 \mathrm{Ma}$ Comments/Comentarios: If the above slip rate is correct, the most recent movement is probably late Quaternary (<50 k.y.).

REFERENCES/REFERENCIAS

Asociación Colombiana de Ingeniería Sísmica (AIS) 1996, INGEOMINAS-Uniandes, Estudio general de la amenaza sísmica en Colombia: INGEOMINAS, Bogotá, 254 p.

Page, W.D., 1986, Seismic geology and seismicity of Northwestern Colombia: San Francisco, California, WoodwardClyde Consultants Report for ISA and Integral Ltda., Medellín, 200 p.

Paris, G., y Romero, J., 1994, Fallas Activas en Colombia: INGEOMINAS, Boletin Geológico, v. 34, no. 2-3, p. 3-26 (Santafé de Bogotá).

Vergara, H., Paris, G., Taboada, A., Romero, y J., Castro, E., 1996, Actividad Neotectónica en las Fuentes Sismogénicas de la Región Central de Colombia: Memorias VII $\left(7^{\text {th }}\right)$ Congreso Colombiano de Geología, INGEOMINAS, Santafé de Bogotá, Colombia, $13 p$.

Vergara, H., Paris, G., Taboada, A., Romero, y J., Castro, E., 1996, Neotectónica del Borde Llanero-Resultados preliminares. Memorias del Seminario de Sismotectónica del Borde Llanero Colombiano, INGEOMINAS, Medellín, 13 p. (CO-29G, Guayuriba Fault).

Woodward-Clyde Consultants, 1982, Preliminary evaluation of seismic hazards and of erosion and sediment sources (geomor phology), Rio Negro-Guayuriba Proyect, Colombia: Report to Gomez Cajiao y Asociados Cia Ltda y la Empresa de Energía de Bogotá, 43p.

\section{CO-29H, ALGECIRAS (FAULT) SECTION, EASTERN FRONTAL FAULT SYSTEM}

SECTION NUMBER/NUMERO DE LA SECCION: CO-29h

SECTION NAME/NOMBRE DE LA SECCION: Algeciras (fault)

SYNOPSIS AND GEOLOGIC SETTING/SINOPSIS Y AMBIENTE GEOLOGICO: The Algeciras fault section crosses the southward narrowing Cordillera Oriental at an oblique angle, with its southern extension following the Cordillera's western flank. The fault displaces Precambrian crystalline shield rocks and Mesozoic granites. Neotectonic deformation is suggested by the formation of a narrow and long pull-apart basin filled with Quaternary sediment. Younger faults cross the basin diagonally. The fault is part of a set of major strike-slip faults that farther north probably join the Guayuriba dextral/reverse fault [CO-29g], which borders the Cordillera Oriental to the northeast.

COMPILER, AFFILIATION, \& DATE OF COMPILATION/COMPILADOR, AFILIACION Y FECHA DE COMPILACION: Gabriel Paris, INGEOMINAS, Bogotá; November 1993. Reviewed January 1997 at CRQ and UNIQUINDIO, Armenia. Revised by Gabriel Paris, Estudios Geológico Mineros, Cali; June 1998: Departamento de Geografía, Universidad del Valle, Cali, December 1999.

TYPE OF STUDIES/TIPOS DE ESTUDIOS: Interpretation of aerial photographs and satellite images, preliminary morphotectonic and neotectonic field studies.

GEOMETRY OF THE SECTION/GEOMETRIA DE LA SECCION:

LENGTH/LONGITUD: $156.5 \mathrm{~km}$ (159.2 km cumulative)

AVERAGE STRIKE/RUMBO PROMEDIO: $51.6^{\circ} \pm 12\left(\mathrm{~N} 51.6^{\circ} \mathrm{E} \pm 12^{\circ}\right)$

AVERAGE DIP/INCLINACION PROMEDIO: Vertical

SENSE OF MOVEMENT/SENTIDO DE MOVIMIENTO: Dextral (right-lateral)

GEOMORPHIC EXPRESSION/EXPRESION GEOMORFOLOGICA: The prominent tectonic alignments through the Algeciras valley center are due to youngest movements of the fault. These include well developed fault valleys and fault-aligned morphotectonic features, truncated alluvial fans, shutter ridges, beheaded drainages, L-shaped spurs, offset streams, hanging valleys, sagponds, linear fault ridges, and scarp inversion (Hans Diederix, personal field observations), and a large primary pull-apart basin with a clearly defined western wall.

RECURRENCE INTERVAL/INTERVALO DE RECURRENCIA: Unknown

SLIP RATE/TASA DE MOVIMIENTO: $1-5 \mathrm{~mm} / \mathrm{yr}$

Comments/Comentarios: High rate estimated from offset of deformed Quaternary features. 
TIME OF MOST RECENT MOVEMENT/EDAD DEL ULTIMO MOVIMIENTO: Quaternary <1.6 Ma Comments/comentarios: If the above slip rate is correct, the most recent movement is probably $<130 \mathrm{ka}$ (late Quaternary) or younger. This fault is very possibly associated with $9^{\text {th }}$ Feb. $1867 \mathrm{M}$ 6.3-6.7 destructive earthquake which affected a large part of southern Colombia including the Bogotá area (Ramirez, 1975). This earthquake was manifested surface rupturing or cracking in the vicinity of El Paraiso, which is situated on the fault trace northeast of Algeciras, as reported by the local population (Hans Diederix, personal field observatios)

REFERENCES/REFERENCIAS

Page, W.D., 1986, Seismic Geology and Seismicity of Northwestern Colombia: San Francisco, California, WoodwardClyde Consultants Report for ISA and Integral Ltda., Medellín, $200 \mathrm{p}$.

Paris, G., y Romero, J., 1994, Fallas Activas en Colombia: INGEOMINAS, Boletin Geológico, v. 34, no. 2-3, p. 3-26 (Santafé de Bogotá).

Ramirez, J.E., 1975, "Historia de los Terremotos de Colombia", Seg. Ed. Instituto Geografico Agustin Codazzi, 250 p., (Bogotá)

Vergara, H., 1996, Rasgos y Actividad Neotectónica en la Falla de Algeciras: Memorias VI $\left(6^{\text {th }}\right)$ Congreso Colombiano de Geología, 10 p. (Bogotá).

\section{CO-29I, GARZON-PITALITO (FAULT) SECTION, EASTERN FRONTAL FAULT SYSTEM}

FAULT NUMBER/NUMERO DE LA FALLA: CO-29i

FAULT NAME/NOMBRE DE LA FALLA: Garzon-Pitalito (fault)

SYNOPSIS AND GEOLOGIC SETTING/SINOPSIS Y AMBIENTE GEOLOGICO: The Garzon-Pitalito fault extends along the western slope of the Cordillera Oriental southeast from the city of Neiva and crosses the upper part of the Magdalena Valley. In the northern half, the fault places Jurassic-Triassic sedimentary rocks on the eastern side in contact with Quaternary alluvium and colluvium on the western side. Along its southern half, the fault places Jurassic-Triassic rocks in contact with Cretaceous rocks. The Garzon-Pitalito fault strikes toward and merges with the Algeciras section [CO-29h] of the Eastern Frontal fault system to the north. To the south it passes the towns of Garzon, Altamira, Timana, Pitalito and San Agustin. In Pitalito, it creates a pull-apart basin (not shown on map owing to scale). The Garzon-Pitalito fault appears to dextrally displace the Suaza fault [CO-29j]. The place of the offset is marked by a large shutteridge near where the Suaza River was dammed by huge landslides as a result of the earthquake of November 16, 1827 (Ramirez, 1975).

COMPILER, AFFILIATION, \& DATE OF COMPILATION/COMPILADOR, AFILIACION Y FECHA DE COMPILACION: Gabriel Paris, INGEOMINAS, Bogotá; November 1993. Reviewed January 1997 at CRQ and UNIQUINDIO, Armenia. Revised by Gabriel Paris, Estudios Geológico Mineros, Cali; June 1998.

TYPE OF STUDIES/TIPOS DE ESTUDIOS: General reconnaissance field studies.

GEOMETRY OF THE FAULT/GEOMETRIA DE LA FALLA:

LENGTH/LONGITUD: $125.5 \mathrm{~km}(128.7 \mathrm{~km}$ cumulative)

AVERAGE STRIKE/RUMBO PROMEDIO: $48.8^{\circ} \pm 13^{\circ}\left(\mathrm{N} 48.9^{\circ} \mathrm{E} \pm 13^{\circ}\right)$

AVERAGE DIP/INCLINACION PROMEDIO: High to the E.

SENSE OF MOVEMENT/SENTIDO DE MOVIMIENTO: Probably dextral (right lateral) and reverse.

GEOMORPHIC EXPRESSION/EXPRESION GEOMORFOLOGICA: The fault trace is marked by

topographically aligned features such as straight valleys, fault saddles, prominent breaks in slope along the fault trace, confined (ponded) Quaternary deposits, shutteridges, sagponds, fault trenches, and pullappart basin. Most of these topographic features show evidence of dextral (right lateral) movement.

RECURRENCE INTERVAL/INTERVALO DE RECURRENCIA: Unknown

SLIP RATE/TASA DE MOVIMIENTO: Probably $1-5 \mathrm{~mm} / \mathrm{yr}$

Comments/Comentarios: High slip rate estimated from similarity youthful geomorphologic features and proximity to the Algeciras section [CO-29h].

TIME OF MOST RECENT MOVEMENT/EDAD DEL ULTIMO MOVIMIENTO: Holocene/post glacial, $<15$ ka Comments/Comentarios: Movement probably as young as Holocene.

REFERENCES/REFERENCIAS

Baker,J. 1990., Tectonic and climatic controls on late Quaternary sedimentary processes in a neotectonic intramontane basin (The Pitalito Basin, South Colombia); PHd. Thesis, Univ. Of Amsterdam, The Netherlands 
Ramirez, J E., 1975, "Historia de los Terremotos de Colombia”, Seg. Ed. Instituto Geografico Agustin Codazzi, 250 p., Bogotá

Vergara, H., 1996, Rasgos y Actividad Neotectónica en la Falla de Algeciras: Memorias VI (6 ${ }^{\text {th }}$ ) Congreso Colombiano de Geología, 10 p. (Bogotá).

\section{CO-29J, SUAZA (FAULT) SECTION, EASTERN FRONTAL FAULT SYSTEM}

FAULT NUMBER/NUMERO DE LA FALLA: CO-29j

FAULT NAME/NOMBRE DE LA FALLA: Suaza

SYNOPSIS AND GEOLOGIC SETTING/SINOPSIS Y AMBIENTE GEOLOGICO: The Suaza fault crosses the western slope of the Cordillera Oriental, close to the upper Magdalena Valley. It puts Precambrian crystalline rocks on the east against Jurassic and Cretaceous sedimentary rocks on the west. Mesozoic granites are also displaced by the fault. A broad and long valley along the fault is filled with Quaternary sediments. Near the town of Suaza, exposures show at least two episodes of neotectonic deformation: 1) early thrusting of Jurassic rocks over older Quaternary deposits, and 2) later deformation affecting the Jurassic rocks, old Quaternary deposits, and the relatively young Quaternary sediments. Most of the fault trace south of the upper Magdalena valley is poorly located and documented. On the basis of regional correlations, it is believed that the Garzon-Suaza fault [CO-29i), the Suaza fault [CO-29j], and the Algeciras fault [CO-29h] all are continuous southward extensions of the Guaicaramo fault sections [CO-29a-c].

COMPILER, AFFILIATION, \& DATE OF COMPILATION/COMPILADOR, AFILIACION Y FECHA DE COMPILACION: Gabriel Paris, INGEOMINAS, Bogotá; November 1993. Reviewed January 1997 at CRQ and UNIQUINDIO, Armenia. Revised by Gabriel Paris, Estudios Geológico Mineros, Cali; June 1998.

TYPE OF STUDIES/TIPOS DE ESTUDIOS: Interpretation of aerial photographs andsatellite images, reconnaissance morphotectonics and neotectonic field studies.

GEOMETRY OF THE FAULT/GEOMETRIA DE LA FALLA: LENGTH/LONGITUD: $125.8 \mathrm{~km}$ (129.4 km cumulative)

AVERAGE STRIKE/RUMBO PROMEDIO: $50.9^{\circ} \pm 15^{\circ}\left(\mathrm{N} 50.9^{\circ} \mathrm{E} \pm 9^{\circ}\right)$

AVERAGE DIP/INCLINACION PROMEDIO: Moderate to the east

SENSE OF MOVEMENT/SENTIDO DE MOVIMIENTO: Dextral (right lateral) and reverse

GEOMORPHIC EXPRESSION/EXPRESION GEOMORFOLOGICA: The fault forms a well-developed valley with displaced Quaternary sediment. It has tilted older Quaternary terraces, causing reverse-gradient slopes and fault saddles.

RECURRENCE INTERVAL/INTERVALO DE RECURRENCIA: Unknown

SLIP RATE/TASA DE MOVIMIENTO: 0.2-1.0 mm/yr

Comments/Comentarios: Unknown to moderate rate (probably $<1.0 \mathrm{~mm} / \mathrm{yr}$ ) is based on geomorphic features and association with Algeciras fault section [CO-29h].

TIME OF MOST RECENT MOVEMENT/EDAD DEL ULTIMO MOVIMIENTO: Quaternary <1.6 Ma REFERENCES/REFERENCIAS

Paris, G., Marin, P., Romero, J., y Wagner, J, J., 1989, "Actividad Neotectónica en el Suroccidente Colombiano": Memorias $5^{\circ}$ Congreso Colombiano de Geología, Bucaramanga, Marzo 14-17: Soc. Col. de Geol., p. $193-213$ (Bogotá).

\section{CO-29K, MOCOA (FAULT) SECTION, EASTERN FRONTAL FAULT SYSTEM}

SECTION NUMBER/NUMERO DE LA SECCION: CO-29k

SECTION NAME/NOMBRE DE LA SECCION: Mocoa (fault)

SYNOPSIS AND GEOLOGIC SETTING/SINOPSIS Y AMBIENTE GEOLOGICO: The Mocoa fault strikes close to the base of the eastern side of the mountain front of the central mountains and coincides with the abrupt change in slope between the Andean Range (on the west) and the dense forest-covered hilly lowlands (on the east). The fault places Cretaceous and Jurassic sedimentary rocks and TertiaryQuaternary volcanics on the west against Precambrian crystalline rocks on the east. 
COMPILER, AFFILIATION, \& DATE OF COMPILATION/COMPILADOR, AFILIACION Y FECHA DE COMPILACION: Gabriel Paris, INGEOMINAS, Bogotá; April 1992. Revised by Gabriel Paris, Estudios Geológico Mineros, Cali; June 1998; Departamento de Geografía Universidad del Valle, December 1999. TYPE OF STUDIES/TIPOS DE ESTUDIOS: Short-duration detailed local geologic studies around the city of Mocoa. Interpretation of aerial photographs, but no systematic neotectonic work has been done.

GEOMETRY OF THE SECTION/GEOMETRIA DE LA SECCION:

LENGTH/LONGITUD: $117.1 \mathrm{~km}$ (119.1 km cumulative)

AVERAGE STRIKE/RUMBO PROMEDIO: $55.1^{\circ} \pm 11^{\circ}\left(\mathrm{N} 55.1^{\circ} \mathrm{E} \pm 11^{\circ}\right)$

AVERAGE DIP/INCLINACION PROMEDIO: Unknown to the west?

The fault may dip to the east as a back thrust associated with west-dipping frontal faults farther to the east. SENSE OF MOVEMENT/SENTIDO DE MOVIMIENTO: Reverse, dextral (right lateral)

Comments/Comentarios: Vertical component is west-side up.

GEOMORPHIC EXPRESSION/EXPRESION GEOMORFOLOGICA: Well marked morphological slope change along the fault line. Fault forms a wide zone of cataclastic rocks, truncates late Tertiary volcanic deposits, and confines (ponds?) Quaternary deposits.

RECURRENCE INTERVAL/INTERVALO DE RECURRENCIA: Unknown

Comments/Comentarios: Low to moderate slip rate estimated from association with moderate to high slip rate faults to north on the Eastern Frontal fault system.

SLIP RATE/TASA DE MOVIMIENTO: Unknown, probably 0.2-1 mm/yr

TIME OF MOST RECENT MOVEMENT/EDAD DEL ULTIMO MOVIMIENTO: Quaternary, $<1.6 \mathrm{Ma}$ Comments/Comentarios: Probably late Quaternary (<130 k.y.), but not documented.

REFERENCES/REFERENCIAS

Hidroestudios Ltda, Ingenieros Consultores, 1982, Estudio de la Variante Mocoa-San Francisco (Putumayo): Realizado para el Ministerio de Obras Públicas y Transporte (MOPT), Bogotá, 718 p.

\section{CO-29L, SIBUNDOY (FAULT) SECTION, EASTERN FRONTAL FAULT SYSTEM}

FAULT NUMBER/NUMERO DE LA FALLA: CO-29I

FAULT NAME/NOMBRE DE LA FALLA: Sibundoy

SYNOPSIS AND GEOLOGIC SETTING/SINOPSIS Y AMBIENTE GEOLOGICO: The Sibundoy fault is located in the "Cordillera Centro-Oriental" to the east of the city of Pasto, which is south of where the cordillera splits in two ranges (Eastern and Central Cordilleras) (this location is known as "Macizo Colombiano"). The Sibundoy fault is probably the southward extension of the Suaza fault [CO-46] and may well be part of the Afiladores fault [CO-35] to the south. At the "Valle de Sibundoy" (the locality where the Sibundoy fault is best studied), the fault displaces Precambrian, Jurassic and Cretaceous rocks, and deforms Quaternary topographic features.

COMPILER, AFFILIATION, \& DATE OF COMPILATION/COMPILADOR, AFILIACION Y FECHA DE COMPILACION: Gabriel Paris, Estudios Geológico Mineros, Cali; June 1998.

TYPE OF STUDIES/TIPOS DE ESTUDIOS: There have been general neotectonic and morphotectonic field studies mainly in the Sibundoy Valley, and detailed neotectonic observations on the eastern, faulted side of the valley. This description of the fault is based on unpublished information from INGEOMINAS and neotectonic work in the area by the compiler in 1988-1989.

GEOMETRY OF THE FAULT/GEOMETRIA DE LA FALLA:

LENGTH/LONGITUD: $57.9 \mathrm{~km}$ (58.5 km cumulative)

AVERAGE STRIKE/RUMBO PROMEDIO: $44.5^{\circ} \pm 9^{\circ}\left(\mathrm{N} 44.5^{\circ} \mathrm{E} \pm 9^{\circ}\right)$

AVERAGE DIP/INCLINACION PROMEDIO: Generally vertical

SENSE OF MOVEMENT/SENTIDO DE MOVIMIENTO: Dextral (right lateral)

Comments/Comentarios: Regionally, vertical component is up to the west. Locally west side is down in pull-apart basins.

GEOMORPHIC EXPRESSION/EXPRESION GEOMORFOLOGICA: Fault has very well defined trace with degraded fault scarps, L-shaped spurs, triangular facets, localized trenches (grabens), linear ridges and fault saddles. Extension has formed a $25-$ by $20-\mathrm{km}$ wide pull apart basin, the eastern boundary of which has the well developed tectonic morphology and evidence of offset Holocene(?) alluvial-fan deposits.

RECURRENCE INTERVAL/INTERVALO DE RECURRENCIA: Unknown 
SLIP RATE/TASA DE MOVIMIENTO: $1-5 \mathrm{~mm} / \mathrm{yr}$

Comments/Comentarios: High rate estimated on basis of the state of preservation of deformed late Quaternary landforms.

TIME OF MOST RECENT MOVEMENT/EDAD DEL ULTIMO MOVIMIENTO: Holocene/post glacial, $<15$ ka Comments/Comentarios: Movement is probably Holocene and possibly historic (1834, see below). No surface rupture has been identified in association with the 1834 earthquake.

NAME OF EARTHQUAKE/NOMBRE DEL TERREMOTO: 1834 Sibundoy

Comments/Comentarios: This was one of the largest historical earthquakes in Colombia

DATE/FECHA: Jan. 20, 1834

MAGNITUDE OR INTENSITY/MAGNITUD O INTENSIDAD: Io X in epicentral area.

REFERENCES/REFERENCIAS

Hidroestudios Ltda, Ingenieros Consultores, 1982, Estudio de la Variante Mocoa-San Francisco (Putumayo): Realizado para el Ministerio de Obras Públicas y Transporte (MOPT), Bogotá, 718 p.

Ramirez, J.E., 1975, "Historia de los Terremotos de Colombia", Seg. E.: Instituto Geográfico Agustín Codazzi, 250 p. (Bogotá).

Unpublished information from INGEOMINAS and neotectonic work in the area by compiler in 1988-1989.

\section{CO-29M, AFILADORES (FAULT) SECTION, EASTERN FRONTAL FAULT SYSTEM}

SECTION NUMBER/NUMERO DE LA FALLA: CO-29m

SECTION NAME/NOMBRE DE LA FALLA: Afiladores (fault)

SYNOPSIS AND GEOLOGIC SETTING/SINOPSIS Y AMBIENTE GEOLOGICO: The Afiladores fault runs through a geographic area of the Andes where the Central and Eastern Ranges merge into a single range known as the Cordillera Centro-Oriental de Colombia. The fault offsets Precambrian gneisses and schists, metamorphic Paleozoic rocks, Mesozoic granitic rocks, and Tertiary sedimentary deposits. The fault extends south into the Republic of Ecuador and probably connects with the Chingual fault [EC-29a].

COMPILER, AFFILIATION, \& DATE OF COMPILATION/COMPILADOR, AFILIACION Y FECHA DE COMPILACION: Gabriel Paris, INGEOMINAS, Bogotá; November 1993. Reviewed January 1997 at CRQ and UNIQUINDIO, Armenia. Revised by Gabriel Paris, Estudios Geológico Mineros, Cali; June 1998 and Departamento de Geografía Universidad del Valle, Cali, December 1999.

TYPE OF STUDIES/TIPOS DE ESTUDIOS: Interpretation of aerial photographs and reconnaissance geologic field studies, preliminary morphotectonic and neotectonic studies.

GEOMETRY OF THE SECTION/GEOMETRIA DE LA SECCION:

LENGTH/LONGITUD: $99.9 \mathrm{~km}$ (101.2 km cumulative)

AVERAGE STRIKE/RUMBO PROMEDIO: $52.1^{\circ} \pm 10^{\circ}\left(\mathrm{N} 52.1^{\circ} \mathrm{E} \pm 10^{\circ}\right)$

AVERAGE DIP/INCLINACION PROMEDIO: Probably to the west.

Comments/Comentarios: The dip direction is mainly inferred from the general attitude of other faults in the area and farther north, to which it probably connects along strike.

SENSE OF MOVEMENT/SENTIDO DE MOVIMIENTO: Reverse, dextral (right lateral)

Comments/Comentarios: The Chingual fault [EC-29a] south in Ecuador is shown as a dextral fault.

GEOMORPHIC EXPRESSION/EXPRESION GEOMORFOLOGICA: Pronounced V-shaped fault valleys in old rocks, well developed scarps on Tertiary rocks, saddles, and small areas of confined (ponded) Quaternary deposits.

RECURRENCE INTERVAL/INTERVALO DE RECURRENCIA: Unknown

SLIP RATE/TASA DE MOVIMIENTO: Unknown, probably 0.2-1 mm/yr

Comments/Comentarios: Low to moderate slip rate estimated from association with moderate to high slip rate faults to north on the Eastern Frontal fault system.

TIME OF MOST RECENT MOVEMENT/EDAD DEL ULTIMO MOVIMIENTO: Quaternary <1.6 Ma. REFERENCES/REFERENCIAS

Paris, G., y Romero, J., 1994, Fallas Activas en Colombia: INGEOMINAS, Boletin Geológico, v. 34, no. 2-3, p. 3-26 (Santafé de Bogotá). 


\section{CO-30, LA MACARENA FAULT}

FAULT NUMBER/NUMERO DE LA FALLA: CO-30

FAULT NAME/NOMBRE DE LA FALLA: La Macarena

SYNOPSIS AND GEOLOGIC SETTING/SINOPSIS Y AMBIENTE GEOLOGICO: The Macarena fault extends along the eastern border of La Serranía de La Macarena, which is an isolated tectonic block to the east of the Eastern Colombian Range. The fault thrusts Precambrian crystalline rocks and Tertiary oceanic rocks on the west over Tertiary and Pleistocene continental rocks on the east.

COMPILER, AFFILIATION, \& DATE OF COMPILATION/COMPILADOR, AFILIACION Y FECHA DE COMPILACION: Gabriel Paris, Estudios Geológico Mineros, Cali; November 1998.

TYPE OF STUDIES/TIPOS DE ESTUDIOS: Interpretation of aerial photograph and radar images.

GEOMETRY OF THE FAULT/GEOMETRIA DE LA FALLA:

LENGTH/LONGITUD: $50.3 \mathrm{~km}$ (50.9 km cumulative)

AVERAGE STRIKE/RUMBO PROMEDIO: $0.6^{\circ} \pm 9^{\circ}\left(\mathrm{N} 0.6^{\circ} \mathrm{E} \pm 9^{\circ}\right)$

AVERAGE DIP/INCLINACION PROMEDIO: Unknown to the west

SENSE OF MOVEMENT/SENTIDO DE MOVIMIENTO: Reverse

Comments/Comentarios: Vertical component is west-side up.

GEOMORPHIC EXPRESSION/EXPRESION GEOMORFOLOGICA: The course of the Guayabero River is controlled by the fault, showing strong lineations. Pleistocene sediment and alluvial terraces are apparently offset. There is a prominent fault scarp on the west side of the river.

RECURRENCE INTERVAL/INTERVALO DE RECURRENCIA: Unknown

SLIP RATE/TASA DE MOVIMIENTO: Unknown, probably $<0.2 \mathrm{~mm} / \mathrm{yr}$.

Comments/Comentarios: There are no field measurements of offset.

TIME OF MOST RECENT MOVEMENT/EDAD DEL ULTIMO MOVIMIENTO: Quaternary $<1.6 \mathrm{Ma}$

REFERENCES/REFERENCIAS

Page, W.D., 1986, Seismic geology and seismicity of Northwestern Colombia: San Francisco, California, WoodwardClyde Consultants Report for ISA and Integral Ltda., Medellín, 200 p.

Woodward-Clyde Consultants, 1982, Preliminary evaluation of seismic hazards and of erosion and sediment sources (geomor phology), Rio Negro-Guayuriba Proyect, Colombia: Report to Gomez Cajiao y Asociados Cia Ltda y la Empresa de Energía de Bogotá, 43p.

\section{CO-31, BOGOTÁ FAULT}

FAULT NUMBER/NUMERO DE LA FALLA: CO-31

FAULT NAME/NOMBRE DE LA FALLA: Bogotá

SYNOPSIS AND GEOLOGIC SETTING/SINOPSIS Y AMBIENTE GEOLOGICO: The Bogotá fault extends along the base of the mountain front that borders the flat old lake deposit known a "La Sabana de Bogotá" to the east. The fault mainly cuts Cretaceous and Tertiary sedimentary rocks and, to some extent, early Quaternary deposits.

COMPILER, AFFILIATION, \& DATE OF COMPILATION/COMPILADOR, AFILIACION Y FECHA DE COMPILACION: Gabriel Paris, Estudios Geológico Mineros, Cali; August 1997.

TYPE OF STUDIES/TIPOS DE ESTUDIOS: Interpretation of aerial photographs, preliminary neotectonic and morphotectonic field studies.

GEOMETRY OF THE FAULT/GEOMETRIA DE LA FALLA:

LENGTH/LONGITUD: $78.8 \mathrm{~km}$ (79.3 km cumulative)

AVERAGE STRIKE/RUMBO PROMEDIO: $13.5^{\circ} \pm 7^{\circ}\left(\mathrm{N} 13.5^{\circ} \mathrm{E} \pm 7^{\circ}\right)$

AVERAGE DIP/INCLINACION PROMEDIO: High to the east

SENSE OF MOVEMENT/SENTIDO DE MOVIMIENTO: Reverse, dextral (right-lateral)

GEOMORPHIC EXPRESSION/EXPRESION GEOMORFOLOGICA: Strong slope change between different geologic units on both sides of the fault plane and degraded fault scarps.

RECURRENCE INTERVAL/INTERVALO DE RECURRENCIA: 10-40 k.y.

Comments/Comentarios: Calculated from slip rate and probable magnitude values. 
SLIP RATE/TASA DE MOVIMIENTO: $<0.2 \mathrm{~mm} / \mathrm{yr}$

Comments/Comentarios: Slip rate of $0.01-0.1 \mathrm{~mm} / \mathrm{yr}$ calculated from displaced geomorphic Quaternary features.

TIME OF MOST RECENT MOVEMENT/EDAD DEL ULTIMO MOVIMIENTO: Quaternary, $<1.6 \mathrm{Ma}$ REFERENCES/REFERENCIAS

Asociación Colombiana de Ingeniería Sísmica (AIS) 1996, INGEOMINAS—Uniandes, Estudio general de la amenaza sísmica en Colombia: INGEOMINAS, Bogotá, $254 \mathrm{p}$.

Vergara, H., Paris, G., Taboada, A., Romero, y J., Castro, E., 1996, Actividad Neotectónica en las Fuentes Sismogénicas de la Región Central de Colombia: Memorias VII $\left(7^{\text {th }}\right)$ Congreso Colombiano de Geología, INGEOMINAS, Santafé de Bogotá, Colombia, $13 p$.

\section{CO-32, VIANI FAULT}

FAULT NUMBER/NUMERO DE LA FALLA: CO-32

FAULT NAME/NOMBRE DE LA FALLA: Viani

SYNOPSIS AND GEOLOGIC SETTING/SINOPSIS Y AMBIENTE GEOLOGICO: The Viani fault is located on the western slope of the Cordillera Oriental of Colombia. The fault places lower Cretaceous rocks to the northwest against upper Cretaceous rock to the southeast.

COMPILER, AFFILIATION, \& DATE OF COMPILATION/COMPILADOR, AFILIACION Y FECHA DE COMPILACION: Gabriel Paris, Estudios Geológico Mineros, Cali; June 1998.

TYPE OF STUDIES/TIPOS DE ESTUDIOS: Reconnaissance (preliminary) neotectonic and morphotectonic field studies.

GEOMETRY OF THE FAULT/GEOMETRIA DE LA FALLA:

LENGTH/LONGITUD: $38.3 \mathrm{~km}$ (39.6 km cumulative)

AVERAGE STRIKE/RUMBO PROMEDIO: $55.5^{\circ} \pm 15\left(\mathrm{~N} 55.5^{\circ} \mathrm{E} \pm 15^{\circ}\right)$

AVERAGE DIP/INCLINACION PROMEDIO: Probably low to medium to the Southeast SENSE OF MOVEMENT/SENTIDO DE MOVIMIENTO: Reverse, dextral (right-lateral)

GEOMORPHIC EXPRESSION/EXPRESION GEOMORFOLOGICA: Trace characterized by offset spurs, degraded fault scarps, saddles, small pull-apart basins, aligned drainage, and deflected streams.

RECURRENCE INTERVAL/INTERVALO DE RECURRENCIA: 10-100 k.y. Comments/Comentarios: Graphic calculation from slip rate and magnitude values. Maximum moment magnitude is estimated to be 7.2 on the basis of probable rupture of entire fault length.

SLIP RATE/TASA DE MOVIMIENTO: $<0.2 \mathrm{~mm} / \mathrm{yr}$ Comments/Comentarios: Slip rate of $0.01-0.1 \mathrm{~mm} / \mathrm{yr}$ based on offset morphologic and neotectonic features.

TIME OF MOST RECENT MOVEMENT/EDAD DEL ULTIMO MOVIMIENTO: Quaternary < $1.6 \mathrm{Ma}$ REFERENCES/REFERENCIAS

Asociación Colombiana de Ingeniería Sísmica (AIS) 1996, INGEOMINAS—Uniandes, Estudio general de la amenaza sísmica en Colombia: INGEOMINAS, Bogotá, $254 \mathrm{p}$.

Vergara, H., Paris, G., Taboada, A., Romero, y J., Castro, E., 1996, Actividad Neotectónica en las Fuentes Sismogénicas de la Región Central de Colombia: Memorias VII $\left(7^{\text {th }}\right)$ Congreso Colombiano de Geología, INGEOMINAS, Santafé de Bogotá, Colombia, $13 p$.

\section{CO-33, USME FAULT}

FAULT NUMBER/NUMERO DE LA FALLA: CO-33

FAULT NAME/NOMBRE DE LA FALLA: Usme

SYNOPSIS AND GEOLOGIC SETTING/SINOPSIS Y AMBIENTE GEOLOGICO: The Usme fault is located in the Cordillera Oriental south of Santafé de Bogotá and extends along the west margin of the Rio Tunjuelito valley. The fault displaces Cretaceous and Tertiary rocks as well as Quaternary alluvial and glacial (moraine) deposits.

COMPILER, AFFILIATION, \& DATE OF COMPILATION/COMPILADOR, AFILIACION Y FECHA DE COMPILACION: Gabriel Paris, Estudios Geológico Mineros, Cali; August 1997.

TYPE OF STUDIES/TIPOS DE ESTUDIOS: Preliminary morphotectonics and neotectonics field studies. 
GEOMETRY OF THE FAULT/GEOMETRIA DE LA FALLA:

LENGTH/LONGITUD: $64.9 \mathrm{~km}$ (65.1 km cumulative)

AVERAGE STRIKE/RUMBO PROMEDIO: $22.7^{\circ} \pm 6^{\circ}\left(\mathrm{N} 22.7^{\circ} \mathrm{E} \pm 6^{\circ}\right)$

AVERAGE DIP/INCLINACION PROMEDIO: High angle to vertical to the east

Comments/Comentarios: The scarp has triangular facets that conform to a normal fault that dips east.

SENSE OF MOVEMENT/SENTIDO DE MOVIMIENTO: Normal, dextral (right-lateral)

Comments/Comentarios: The west-side of the fault is probably up. The fault valley shows features

suggesting a half graben with a steep slope wall on the west and low-angle slope on the east.

GEOMORPHIC EXPRESSION/EXPRESION GEOMORFOLOGICA: The fault forms a steep, prominent (ca.

40-m-high) east-facing scarp on Cretaceous rocks that show initial development of triangular facets. The

hanging valleys have Quaternary alluvial deposits on the west (uplifted) block. The scarp forms the

western wall of a narrow and long valley (graben?). To the south of Santafé de Bogotá, it appears that

Pleistocene moraines are offset as recorded by east-facing well-preserved scarps about $3 \mathrm{~m}$ high.

RECURRENCE INTERVAL/INTERVALO DE RECURRENCIA: Unknown

SLIP RATE/TASA DE MOVIMIENTO: $1-5 \mathrm{~mm} / \mathrm{yr}$

Comments/Comentarios: Slip rate of $2.0 \mathrm{~mm} / \mathrm{yr}$ calculated on basis of amount of displacement of

Quaternary alluvial (gravel) deposits.

TIME OF MOST RECENT MOVEMENT/EDAD DEL ULTIMO MOVIMIENTO: Holocene/post glacial, <15 ka Comments/Comentarios: Holocene or latest Pleistocene; probably historic according to Espinosa (1989).

REFERENCES/REFERENCIAS

Asociación Colombiana de Ingeniería Sísmica (AIS) 1996, INGEOMINAS—Uniandes, Estudio general de la amenaza sísmica en Colombia: INGEOMINAS, Bogotá, 254 p.

Espinosa, A., 1989, Hacia un Nuevo Catálogo Colombiano de Simicidad Histórica: Memorias $V\left(5^{\text {th }}\right)$ Congreso Colombiano de Geología, Tomo 1, Bucaramanga, $12 p$.

Vergara, H., Paris, G., Taboada, A., Romero, y J., Castro, E., 1996, Actividad Neotectónica en las Fuentes Sismogénicas de la Región Central de Colombia: Memorias VII $\left(7^{\text {h }}\right)$ Congreso Colombiano de Geología, INGEOMINAS, Santafé de Bogotá, Colombia, $13 p$.

\section{CO-34, CUCUANA FAULT}

FAULT NUMBER/NUMERO DE LA FALLA: CO-34

FAULT NAME/NOMBRE DE LA FALLA: Cucuana

SYNOPSIS AND GEOLOGIC SETTING/SINOPSIS Y AMBIENTE GEOLOGICO: The Cucuana fault is parallel to and south of the Ibagué fault [CO-35] in the Cordillera Central, crossing Paleozoic metamorphic rocks, Mesozoic igneous rocks (Ibagué batholith), and Tertiary beds. The fault extends into the Cordillera Oriental across the Magdalena Valley, cutting Cretaceous beds. The Quaternary sedimentary and volcanic fill of the Magdalena River valley is not reported as having been deformed by the fault.

COMPILER, AFFILIATION, \& DATE OF COMPILATION/COMPILADOR, AFILIACION Y FECHA DE COMPILACION: Gabriel Paris, Estudios Geológico Mineros, Cali; June 1998.

TYPE OF STUDIES/TIPOS DE ESTUDIOS: Regional geomorphology and neotectonic studies.

GEOMETRY OF THE FAULT/GEOMETRIA DE LA FALLA:

LENGTH/LONGITUD: $141.4 \mathrm{~km}$ (142.1 km cumulative)

AVERAGE STRIKE/RUMBO PROMEDIO: $67.9^{\circ} \pm 6^{\circ}\left(\mathrm{N} 67.9^{\circ} \mathrm{E} \pm 6^{\circ}\right)$

AVERAGE DIP/INCLINACION PROMEDIO: Vertical

SENSE OF MOVEMENT/SENTIDO DE MOVIMIENTO: Dextral (right-lateral)

GEOMORPHIC EXPRESSION/EXPRESION GEOMORFOLOGICA: This fault has a prominent trace on

satellite images. It has displaced drainages, spurs, fault saddles, and formed triangular facets, and appears to structurally control the course of the Cucuana River.

RECURRENCE INTERVAL/INTERVALO DE RECURRENCIA: 600-6,000 yrs

Comments/Comentarios: From slip rate and magnitude values using graphical relations.

SLIP RATE/TASA DE MOVIMIENTO: $<0.2 \mathrm{~mm} / \mathrm{yr}$

Comments/Comentarios: Slip rate of $0.01-0.1 \mathrm{~mm} / \mathrm{yr}$ based on displaced Quaternary morphologic

features.

TIME OF MOST RECENT MOVEMENT/EDAD DEL ULTIMO MOVIMIENTO: Quaternary <1.6 Ma 


\section{REFERENCES/REFERENCIAS}

Asociación Colombiana de Ingeniería Sísmica (AIS) 1996, INGEOMINAS-Uniandes, Estudio general de la amenaza sísmica en Colombia: INGEOMINAS, Bogotá, $254 \mathrm{p}$.

Vergara, H., 1989, Rasgos Neotectónicos en el Departamento del Tolima: INGEOMINAS, Boletin Geológico, v. 30, no. 1, p. 21-42 (Santafé de Bogotá).

\section{CO-35, IBAGUÉ FAULT}

FAULT NUMBER/NUMERO DE LA FALLA: CO-35

FAULT NAME/NOMBRE DE LA FALLA: Ibagué

SYNOPSIS AND GEOLOGIC SETTING/SINOPSIS Y AMBIENTE GEOLOGICO: The Ibagué fault crosses the central part and eastern slope of the Colombian Cordillera Central, close to the city of Ibagué. The fault cuts Precambrian rocks and the Jurassic age Ibagué batholith. The fault strikes WSW-ENE controlling the Cocora River and displacing and deforming the Neogene Ibagué fan (Abanico de Ibagué), which is of volcano-sedimentary origin.

COMPILER, AFFILIATION, \& DATE OF COMPILATION/COMPILADOR, AFILIACION Y FECHA DE COMPILACION: Gabriel Paris, INGEOMINAS, Bogotá; November 1993. Reviewed January 1997 at CRQ and UNIQUINDIO, Armenia. Revised by Gabriel Paris, Estudios Geológico Mineros, Cali; June 1998.

TYPE OF STUDIES/TIPOS DE ESTUDIOS: Field reconnaissance, neotectonic studies, radiocarbon dating, and interpretation of photogeology and radar imagery.

GEOMETRY OF THE FAULT/GEOMETRIA DE LA FALLA: LENGTH/LONGITUD: $123.9 \mathrm{~km}$ (126.1 km cumulative) AVERAGE STRIKE/RUMBO PROMEDIO: $67.9^{\circ} \pm 11^{\circ}\left(\mathrm{N} 67.9^{\circ} \mathrm{E} \pm 11^{\circ}\right)$ AVERAGE DIP/INCLINACION PROMEDIO: Commonly vertical SENSE OF MOVEMENT/SENTIDO DE MOVIMIENTO: Dextral (right-lateral), slightly oblique Comments/Comentarios: Dextral displacement of terrain irregularities show alternating scarplets on both sides of the fault. Vertical component is probably south-side up.

GEOMORPHIC EXPRESSION/EXPRESION GEOMORFOLOGICA: Well developed fault trace with prominent linear fault ridges (whale backs) as much as $800-\mathrm{m}$ long and $50-\mathrm{m}$ high, fault scarplets aligned with ridges, sag ponds, fault-controlled drainage, tilted deposits and upwarping. There is about $600 \mathrm{~m}$ of (young) displacement along strike as calculated by Diederix (1987) from a "whale back" offset by the fault.

RECURRENCE INTERVAL/INTERVALO DE RECURRENCIA: 500-5,000 yrs Comments/Comentarios: Calculated moment magnitude of 7.0-7.2 is based on most probable fault rupture length of about $45 \mathrm{~km}$, from lbagué to Piedras. Total length of fault is slightly over $100 \mathrm{~km}$.

SLIP RATE/TASA DE MOVIMIENTO: $1-5 \mathrm{~mm} / \mathrm{yr}$ Comments/Comentarios: A rate of $1.2 \mathrm{~mm} / \mathrm{yr}$ is published based on deformed and offset Quaternary features and dated deposits (Vergara, 1989)

TIME OF MOST RECENT MOVEMENT/EDAD DEL ULTIMO MOVIMIENTO: Holocene/post glacial, $<15 \mathrm{ka}$ Comments/Comentarios: Most recent movement is about 3,500 yrs ago on basis of dated deposits ((Diederix, 1987)

\section{REFERENCES/REFERENCIAS}

Diederix, H., Gomez, H., Khobzi, J., y Singer, A., 1987, Indicios Neotectónicos en la Falla de Ibague-Piedras, Departamento del Tolima, Colombia: Revista CIAF (Centro Interamericano de Fotointerpretación), v. 11, no. 1-3, p. 242-252 (Bogotá).

Page, W.D., 1986, Seismic geology and seismicity of Northwestern Colombia: San Francisco, California, WoodwardClyde Consultants Report for ISA and Integral Ltda., Medellín, $200 \mathrm{p}$.

Paris, G., y Romero, J., 1994, Fallas Activas en Colombia: INGEOMINAS, Boletin Geológico, v. 34, no. 2-3, p. 3-26 (Santafé de Bogotá).

Vergara, H., 1989, Rasgos Neotectónicos en el Departamento del Tolima: INGEOMINAS, Boletin Geológico, v. 30 , no. 1, p. 21-42 (Santafé de Bogotá).

Vergara, H., 1989, H., Actividad Neotectónica en la Falla de Ibagué: Memorias V ( $\left.5^{\text {th }}\right)$ Congreso Colombiano de Geología, Tomo 1, Bucaramanga, p. 24-27. 


\section{CO-36, TORO FAULT}

FAULT NUMBER/NUMERO DE LA FALLA: CO-36

FAULT NAME/NOMBRE DE LA FALLA: Toro

SYNOPSIS AND GEOLOGIC SETTING/SINOPSIS Y AMBIENTE GEOLOGICO: The Toro fault cuts accreted oceanic rocks of the Cordillera Occidental, close to the Cauca River valley. It is one of the faults of the regional Cauca-Patia fault system that bounds the eastern side of the Cordillera Occidental along most of the range's length.

COMPILER, AFFILIATION, \& DATE OF COMPILATION/COMPILADOR, AFILIACION Y FECHA DE COMPILACION: Gabriel Paris, Estudios Geológico Mineros, Cali; June 1998.

TYPE OF STUDIES/TIPOS DE ESTUDIOS: Neotectonic reconnaissance field studies.

GEOMETRY OF THE SECTION/GEOMETRIA DE LA SECCION:

LENGTH/LONGITUD: $61.9 \mathrm{~km}$ (61.8 km cumulative)

AVERAGE STRIKE/RUMBO PROMEDIO: $6.6^{\circ} \pm 8^{\circ}\left(\mathrm{N} 6.6^{\circ} \mathrm{E} \pm 8^{\circ}\right)$

AVERAGE DIP/INCLINACION PROMEDIO: Unknown

Comments/Comentarios: According to the general geologic setting of most of Cali-Patia fault system, the Toro fault should dip to the west. However, some morphologic features and the rugged indented boundary between the range front and the valley suggest that the Toro fault is instead an east-dipping fault.

SENSE OF MOVEMENT/SENTIDO DE MOVIMIENTO: Sinistral (left-lateral)

Comments/Comentarios: Sense based on slight development of L-shaped (sinistral) spurs in deeply eroded scarp.

GEOMORPHIC EXPRESSION/EXPRESION GEOMORFOLOGICA: This well developed fault trace has an eroded fault scarp, degraded triangular facets, and the fronts of spurs show evidence of sinistral deformation.

RECURRENCE INTERVAL/INTERVALO DE RECURRENCIA: Unknown

SLIP RATE/TASA DE MOVIMIENTO: $<0.2 \mathrm{~mm} / \mathrm{yr}$

Comments/Comentarios: Low rate estimate based on Quaternary deformation of topographic features (Page, 1986).

TIME OF MOST RECENT MOVEMENT/EDAD DEL ULTIMO MOVIMIENTO: Quaternary < $1.6 \mathrm{Ma}$ REFERENCES/REFERENCIAS

Guzman, J., Franco, G., y Ochoa, M., 1998 "Proyecto Para La Mitigacion del Riesgo Sísmico de Pereira, Dosquebradas y Santa Rosa de Cabal "Evaluación Neotectónica": CARDER (Corporación Regional de Risaralda), Pereira, $144 \mathrm{p}$.

Page, W.D., 1986, Seismic geology and seismicity of Northwestern Colombia: San Francisco, California, WoodwardClyde Consultants Report for ISA and Integral Ltda., Medellín, 200 p.

Page, W.D., 1986, Geología Sísmica y Sismicidad del Noroccidente de Colombia: San Francisco, California, Woodward-Clyde Consultants unpublished report for Integral Ltda., and ISA, Medellín, p. 169-174.

Paris, G., y Romero, J., 1994, Fallas Activas en Colombia: INGEOMINAS, Boletin Geológico, v. 34, no. 2-3, p. 3-26 (Santafé de Bogotá).

Ramirez, J.E., 1975, "Historia de los Terremotos de Colombia", Seg. E.: Instituto Geográfico Agustín Codazzi, 250 p. (Bogotá).

\section{CO-37, ARGELIA FAULT}

FAULT NUMBER/NUMERO DE LA FALLA: CO-37

FAULT NAME/NOMBRE DE LA FALLA: Argelia

SYNOPSIS AND GEOLOGIC SETTING/SINOPSIS Y AMBIENTE GEOLOGICO: The Argelia fault is located in the Cordillera Occidental, to the west of the city of Pereira. The fault cuts Mesozoic oceanic rocks that were accreted to the continent during late Cretaceous time. The Argelia fault shows some neotectonic features and probably connects with the Garrapatas fault [CO-38].

COMPILER, AFFILIATION, \& DATE OF COMPILATION/COMPILADOR, AFILIACION Y FECHA DE COMPILACION: Gabriel Paris, Estudios Geológico Mineros, Cali; June 1998.

TYPE OF STUDIES/TIPOS DE ESTUDIOS: General reconnaissance studies for neotectonics. 
GEOMETRY OF THE FAULT/GEOMETRIA DE LA FALLA:

LENGTH/LONGITUD: $59.4 \mathrm{~km}$ (59.5 km cumulative)

AVERAGE STRIKE/RUMBO PROMEDIO: $14.5^{\circ} \pm 18^{\circ}\left(\mathrm{N} 14.5^{\circ} \mathrm{E} \pm 18^{\circ}\right)$

AVERAGE DIP/INCLINACION PROMEDIO: Moderate to high to the west

Comments/Comentarios: Dip estimated by Guzman (1998).

SENSE OF MOVEMENT/SENTIDO DE MOVIMIENTO: Very likely reverse and probably dextral (right lateral)

Comments/Comentarios: Vertical component is west-side up. Dextral movement in this fault is an

exception to the common sinistral (left-lateral) movement of N-S trending faults in the regional. However, it matches well with the sense of movement for the associated Garrapatas fault [CO-38].

GEOMORPHIC EXPRESSION/EXPRESION GEOMORFOLOGICA: Most large spurs seem to be displaced (bent) in a dextral (right-lateral) sense.

RECURRENCE INTERVAL/INTERVALO DE RECURRENCIA: Unknown

SLIP RATE/TASA DE MOVIMIENTO: Unknown, probably $<0.2 \mathrm{~mm} / \mathrm{yr}$

TIME OF MOST RECENT MOVEMENT/EDAD DEL ULTIMO MOVIMIENTO: Quaternary(?), <1.6 Ma REFERENCES/REFERENCIAS

Guzman, J., Franco, G., y Ochoa, M., 1998 "Proyecto Para La Mitigacion del Riesgo Sísmico de Pereira, Dosquebradas y Santa Rosa de Cabal "Evaluación Neotectónica": CARDER (Corporación Regional de Risaralda), Pereira, $144 \mathrm{p}$.

\section{CO-38, GARRAPATAS FAULT}

FAULT NUMBER/NUMERO DE LA FALLA: CO-38

FAULT NAME/NOMBRE DE LA FALLA: Garrapatas

SYNOPSIS AND GEOLOGIC SETTING/SINOPSIS Y AMBIENTE GEOLOGICO: The fault has a very well developed V-shaped valley along the upper parts of the Garrapatas and Las Vueltas rivers. The fault is located to the west of the city of Buga. The fault runs between the axis of the Cordillera Occidental and Los Paraguas Hills and displaces oceanic volcanic and sedimentary rocks. It probably connects with the Argelia fault [CO-37].

COMPILER, AFFILIATION, \& DATE OF COMPILATION/COMPILADOR, AFILIACION Y FECHA DE COMPILACION: Gabriel Paris, INGEOMINAS, Bogotá; November 1993. Reviewed January 1997 at CRQ and UNIQUINDIO, Armenia. Revised by Gabriel Paris, Estudios Geológico Mineros, Cali; June 1998.

TYPE OF STUDIES/TIPOS DE ESTUDIOS: Interpretation of aerial photographs and reconnaissance geologic field studies.

GEOMETRY OF THE FAULT/GEOMETRIA DE LA FALLA:

LENGTH/LONGITUD: $138.0 \mathrm{~km}$ (140.7 km cumulative)

AVERAGE STRIKE/RUMBO PROMEDIO: $60.8^{\circ} \pm 14^{\circ}\left(\mathrm{N} 60.8^{\circ} \mathrm{E} \pm 14^{\circ}\right)$

AVERAGE DIP/INCLINACION PROMEDIO: $50^{\circ} \mathrm{NW}$

SENSE OF MOVEMENT/SENTIDO DE MOVIMIENTO: Reverse, probably dextral (right-lateral)

GEOMORPHIC EXPRESSION/EXPRESION GEOMORFOLOGICA: Fault forms deep V-shaped valleys, and causes alignment of drainage and parallel streams.

RECURRENCE INTERVAL/INTERVALO DE RECURRENCIA: Unknown

SLIP RATE/TASA DE MOVIMIENTO: Unknown, probably $<0.2 \mathrm{~mm} / \mathrm{yr}$

TIME OF MOST RECENT MOVEMENT/EDAD DEL ULTIMO MOVIMIENTO: Quaternary? <1.6 Ma

Comments/Comentarios: Possibly Pliocene if not Quaternary.

REFERENCES/REFERENCIAS

Page, W.D., 1986, Seismic geology and seismicity of Northwestern Colombia: San Francisco, California, WoodwardClyde Consultants Report for ISA and Integral Ltda., Medellín, 200 p.

Paris, G., y Romero, J., 1994, Fallas Activas en Colombia: INGEOMINAS, Boletin Geológico, v. 34, no. 2-3, p. 3-26 (Santafé de Bogotá). 


\section{CO-39, DAGUA-CALIMA FAULT SYSTEM}

FAULT NUMBER/NUMERO DE LA FALLA: CO-39

FAULT NAME/NOMBRE DE LA FALLA: Dagua-Calima (fault system)

SYNOPSIS AND GEOLOGIC SETTING/SINOPSIS Y AMBIENTE GEOLOGICO: The fault displaces oceanic Cretaceous rocks on the middle part of the eastern slope of the Cordillera Occidental in southwestern Colombia, to the northwest of the city of Cali. The fault places oceanic volcanic rock against sedimentary rock, causing about $200 \mathrm{~m}$ of displacement of a Tertiary erosion surface (or peneplain) across the fault. Part of the displacement occurred during the Andean Orogeny. Locally, toward the southern half of the fault, the east-facing scarp is associated with a graben (basin) $3-5 \mathrm{~km}$ wide and about $20 \mathrm{~km}$ long, which is partially filled with Quaternary river deposits.

COMPILER, AFFILIATION, \& DATE OF COMPILATION/COMPILADOR, AFILIACION Y FECHA DE COMPILACION: Gabriel Paris, INGEOMINAS, Bogotá; November 1993. Reviewed January 1997 at CRQ and UNIQUINDIO, Armenia. Revised by Gabriel Paris, Estudios Geológico Mineros, Cali; June 1998: Departamento de Geografía Universidad del Valle, Cali, December 1999.

TYPE OF STUDIES/TIPOS DE ESTUDIOS: Interpretation of aerial photographs, detailed neotectonic and morphotectonic studies. Paleoseismic study of trenches by Woodward-Clyde Consultants in 1983 (see reference below).

GEOMETRY OF THE FAULT/GEOMETRIA DE LA FALLA:

LENGTH/LONGITUD: $121.8 \mathrm{~km}$ (214.9 km cumulative)

AVERAGE STRIKE/RUMBO PROMEDIO: $18.8^{\circ} \pm 20^{\circ}\left(\mathrm{N} 18.8^{\circ} \mathrm{E} \pm 20^{\circ}\right)$

AVERAGE DIP/INCLINACION PROMEDIO: $70^{\circ} \mathrm{E}-\mathrm{SE}$

SENSE OF MOVEMENT/SENTIDO DE MOVIMIENTO: Normal

Comments/Comentarios: West-side up.

GEOMORPHIC EXPRESSION/EXPRESION GEOMORFOLOGICA: Displacement (uplift) of a Tertiary erosion surface and offset of Quaternary alluvial fans. Trace of fault has well developed scarps, triangular facets with "wine glass" valleys, trapezoidal facets, retreated and degraded fault scarps, outstanding fault line.

RECURRENCE INTERVAL/INTERVALO DE RECURRENCIA: 8-10 k.y.

Comments/Comentarios: Calculation from slip rate and estimated magnitude of surface-rupturing earthquakes.

SLIP RATE/TASA DE MOVIMIENTO: $<0.2 \mathrm{~mm} / \mathrm{yr}$

Comments/Comentarios: Slip rate of $<0.1 \mathrm{~mm} / \mathrm{yr}$ was calculated from offset pre-Holocene sediments in trenches opened along the fault trace by Woodward-Clyde Consultants (1983), near Lago Calima.

TIME OF MOST RECENT MOVEMENT/EDAD DEL ULTIMO MOVIMIENTO: Quaternary, <1.6 Ma REFERENCES/REFERENCIAS

Page, W.D., 1986, Seismic geology and seismicity of Northwestern Colombia: San Francisco, California, WoodwardClyde Consultants Report for ISA and Integral Ltda., Medellín, 200 p.

Paris, G., 1993, Investigación Neotectónica en los Sistemas de Falla de Romeral y Cali-Patía, Departamento del Valle, Colombia: VI Seminario Internacional sobre Ingeniería Sísmica, Universidad de los Andes, Santafé de Bogotá, p. 1-29.

Paris, G., y Souret, B., 1993, Microzonificación Sismogeotécnica de Popayán. Subproyecto Neotectónica. Proyecto Colombo-Europeo No. CCE NA 84/03: Comunidad Economica Europea-INGEOMINAS-BRGM-ADK-KS, Publicaciones Especiales de INGEOMINAS, no. 2, p. 28-49, Bogotá.

Paris, G., y Romero, J., 1994, Fallas Activas en Colombia: INGEOMINAS, Boletin Geológico, v. 34, no. 2-3, p. 3-26 (Santafé de Bogotá).

Woodward-Clyde Consultants, 1983, Seismic Hazard Evaluation Calima III proyect: Consorcio Integral-Planes, Ltda., Ingenieros Consultores 1a parte, Corporación Autónoma Regional del Cauca (CVC), Cali, Colombia, 116 p.

\section{CO-40, EL TAMBOR FAULT}

FAULT NUMBER/NUMERO DE LA FALLA: CO-40

FAULT NAME/NOMBRE DE LA FALLA: EI Tambor

SYNOPSIS AND GEOLOGIC SETTING/SINOPSIS Y AMBIENTE GEOLOGICO: The fault borders the western slope of the Cordillea Occidental. Through most of its trace, the fault places Cretaceous volcanic and 
sedimentry rocks on the east, against Neogene rock on the west, which commonly crops out across most of the plains of the Pacific Coast.

COMPILER, AFFILIATION, \& DATE OF COMPILATION/COMPILADOR, AFILIACION Y FECHA DE COMPILACION: Gabriel Paris, INGEOMINAS, Bogotá; November 1993. Reviewed January 1997 at CRQ and UNIQUINDIO, Armenia. Revised by Gabriel Paris, Estudios Geológico Mineros, Cali; June 1998.

TYPE OF STUDIES/TIPOS DE ESTUDIOS: Interpretation of aerial photographs and satellite images, general reconnaissance field studies. Area has been observed by helicopter.

GEOMETRY OF THE FAULT/GEOMETRIA DE LA FALLA:

LENGTH/LONGITUD: $117.5 \mathrm{~km}$ (118.7 km cumulative)

AVERAGE STRIKE/RUMBO PROMEDIO: $26.1^{\circ} \pm 9^{\circ}\left(\mathrm{N} 26.1^{\circ} \mathrm{E} \pm 9^{\circ}\right)$

AVERAGE DIP/INCLINACION PROMEDIO: Probably high angle to the east

SENSE OF MOVEMENT/SENTIDO DE MOVIMIENTO: Reverse, dextral? (right-lateral)

GEOMORPHIC EXPRESSION/EXPRESION GEOMORFOLOGICA: Strong linear topographic features, tectonic control of drainage, and deflected stream channels.

RECURRENCE INTERVAL/INTERVALO DE RECURRENCIA: Unknown

SLIP RATE/TASA DE MOVIMIENTO: Unknown, probably $<0.2 \mathrm{~mm} / \mathrm{yr}$

TIME OF MOST RECENT MOVEMENT/EDAD DEL ULTIMO MOVIMIENTO: Holocene/post glacial, <15 ka Comments/Comentarios: Movement is probably latest Pleistocene (Gomez, 1988).

REFERENCES/REFERENCIAS

Gomez, H., 1988, Algunos aspectos Neotectónicos hacia el Suroeste del litoral Pácifico surcolombiano. Revista CIAF (Centro Interamericano de Fotointerpretación), v. 11, no. 1-3, p. 281-298 (Bogotá).

Paris, G., y Romero, J., 1994, Fallas Activas en Colombia: INGEOMINAS, Boletin Geológico, v. 34, no. 2-3, p. 3-26 (Santafé de Bogotá).

\section{CO-41, NAYA-MICAY FAULT}

FAULT NUMBER/NUMERO DE LA FALLA: CO-41

FAULT NAME/NOMBRE DE LA FALLA: Naya-Micay

SYNOPSIS AND GEOLOGIC SETTING/SINOPSIS Y AMBIENTE GEOLOGICO: The Naya-Micay fault runs parallel to and inland of the southwestern Pacific Coast of Colombia in the Cauca and Valle del Cauca departaments (states). The fault displaces marine and non-marine Pliocene sedimentary rocks. It locally offsets undifferentiated Quaternary alluvial deposits. In general, there are uplifted Tertiary sediments on the east and Quaternary sediments on the western side of the fault. The fault appears to be a northern continuation of the Remolino-El Charco fault [CO-42].

COMPILER, AFFILIATION, \& DATE OF COMPILATION/COMPILADOR, AFILIACION Y FECHA DE COMPILACION: Gabriel Paris, INGEOMINAS, Bogotá; November 1993. Reviewed January 1997 at CRQ and UNIQUINDIO, Armenia. Revised by Gabriel Paris, Estudios Geológico Mineros, Cali; June 1998.

TYPE OF STUDIES/TIPOS DE ESTUDIOS: Interpretation of aerial photographs, reconnaissance geologic field studies.

GEOMETRY OF THE FAULT/GEOMETRIA DE LA FALLA:

LENGTH/LONGITUD: $158.2 \mathrm{~km}$ (160.6 km cumulative)

AVERAGE STRIKE/RUMBO PROMEDIO: $34.1^{\circ} \pm 12^{\circ}\left(\mathrm{N} 34.1^{\circ} \mathrm{E} \pm 12^{\circ}\right)$

AVERAGE DIP/INCLINACION PROMEDIO: Unknown, to the east?

SENSE OF MOVEMENT/SENTIDO DE MOVIMIENTO: Dextral (right lateral) oblique

Comments/Comentarios: East-side up? The southeastern block is tilted to the southwest.

GEOMORPHIC EXPRESSION/EXPRESION GEOMORFOLOGICA: Fault controls drainage of the Rio Guapi, locally offsets Quaternary deposits, and forms folded paleosoils, elongated basins and ridges and has strong general linear features. Along the coast, it forms typical fault-contolled linear landforms.

RECURRENCE INTERVAL/INTERVALO DE RECURRENCIA: Unknown

SLIP RATE/TASA DE MOVIMIENTO: 0.2-1.0 mm/yr

Comments/Comentarios: Low to medium rate of $<1.0 \mathrm{~mm} / \mathrm{yr}$ was estimated from offset Quaternary deposits.

TIME OF MOST RECENT MOVEMENT/EDAD DEL ULTIMO MOVIMIENTO: Quaternary, <1.6 Ma 
REFERENCES/REFERENCIAS

Gomez, H., 1988, Algunos aspectos Neotectónicos hacia el Suroeste del litoral Pácifico surcolombiano. Revista CIAF (Centro Interamericano de Fotointerpretación), v. 11, no. 1-3, p. $281-298$ (Bogotá).

Paris, G., y Romero, J., 1994, Fallas Activas en Colombia: INGEOMINAS, Boletin Geológico, v. 34, no. 2-3, p. 3-26 (Santafé de Bogotá).

\section{CO-42, REMOLINO-EL CHARCO FAULT}

FAULT NUMBER/NUMERO DE LA FALLA: CO-42

FAULT NAME/NOMBRE DE LA FALLA: Remolino-El Charco

SYNOPSIS AND GEOLOGIC SETTING/SINOPSIS Y AMBIENTE GEOLOGICO: The Remolino-EI Charco fault extends through the Pacific coastal lowlands and plains of Colombia to the east of the city of Tumaco. It is close to and parallels the coast. It displaces alluvial-fan sediment of the Patia, Mira, and Telembí rivers and some Pleistocene marine terraces. The fault appears to be a southern continuation of the Naya-Micay fault [CO-41].

COMPILER, AFFILIATION, \& DATE OF COMPILATION/COMPILADOR, AFILIACION Y FECHA DE COMPILACION: Gabriel Paris, INGEOMINAS, Bogotá; November, 1993. Revised by Gabriel Paris, Estudios Geológico Mineros, Cali; June 1998.

TYPE OF STUDIES/TIPOS DE ESTUDIOS: Interpretation of aerial photographs and geologic field studies.

GEOMETRY OF THE FAULT/GEOMETRIA DE LA FALLA:

LENGTH/LONGITUD: $148.7 \mathrm{~km}$ (149.5 km cumulative)

AVERAGE STRIKE/RUMBO PROMEDIO: $46.4^{\circ} \pm 6^{\circ}\left(\mathrm{N} 46.4^{\circ} \mathrm{E} \pm 6^{\circ}\right)$

AVERAGE DIP/INCLINACION PROMEDIO: Probably vertical

SENSE OF MOVEMENT/SENTIDO DE MOVIMIENTO: Probably dextral (right-lateral) oblique

Comments/Comentarios: Vertical component is west-side up.

GEOMORPHIC EXPRESSION/EXPRESION GEOMORFOLOGICA: Very well defined fault line on aerial photographs and satellite images. Pattern of deflection of streams suggests west side of fault is up.

RECURRENCE INTERVAL/INTERVALO DE RECURRENCIA: Unknown

SLIP RATE/TASA DE MOVIMIENTO: Unknown, probably $<0.2 \mathrm{~mm} / \mathrm{yr}$

TIME OF MOST RECENT MOVEMENT/EDAD DEL ULTIMO MOVIMIENTO: Quaternary $<1.6$ Ma.

REFERENCES/REFERENCIAS

Gomez, H., 1988, Algunos aspectos Neotectónicos hacia el Suroeste del litoral Pácifico surcolombiano: Revista CIAF (Centro Interamericano de Fotointerpretación), v. 11, no. 1-3, p. 281-298 (Bogotá).

Paris, G., y Romero, J., 1994, Fallas Activas en Colombia: INGEOMINAS, Boletin Geológico, v. 34, no. 2-3, p. 3-26 (Santafé de Bogotá).

\section{CO-43, PIEDRANCHA FAULT}

FAULT NUMBER/NUMERO DE LA FALLA: CO-43

FAULT NAME/NOMBRE DE LA FALLA: Piedrancha

SYNOPSIS AND GEOLOGIC SETTING/SINOPSIS Y AMBIENTE GEOLOGICO: The Piedrancha fault is in southwestern Colombia, on the western slope of the Cordillera Occidental and to the west of the city of Pasto. The fault places Cretaceous oceanic rock on the west against Cenozoic volcanic rock on the east. The fault is believed to extend south into the Republic of Ecuador. There is no published information available for this fault. Observations of fault morphology are from compiler's field reconnaissance for other geologic projects.

COMPILER, AFFILIATION, \& DATE OF COMPILATION/COMPILADOR, AFILIACION Y FECHA DE COMPILACION: Gabriel Paris, INGEOMINAS, Bogotá; August 1993. Revised by Gabriel Paris, Estudios Geológico Mineros, Cali; August 1998.

TYPE OF STUDIES/TIPOS DE ESTUDIOS: Interpretation of aerial photographs and reconnaissance geologic field studies for mineral exploration projects.

GEOMETRY OF THE FAULT/GEOMETRIA DE LA FALLA:

LENGTH/LONGITUD: $79.5 \mathrm{~km}$ (81.0 km cumulative)

AVERAGE STRIKE/RUMBO PROMEDIO: $33.8^{\circ} \pm 14^{\circ}\left(\mathrm{N} 33.8^{\circ} \mathrm{E} \pm 14^{\circ}\right)$ 
AVERAGE DIP/INCLINACION PROMEDIO: Probably to the east or vertical.

SENSE OF MOVEMENT/SENTIDO DE MOVIMIENTO: Probably dextral (right-lateral) oblique

Comments/Comentarios: Vertical component is east-side up. Sense is compatible with the WSW-ENE compressional stress field in the area.

GEOMORPHIC EXPRESSION/EXPRESION GEOMORFOLOGICA: Trace characterized by fault line and faultcontrolled valley, fault scarps onTertiary-Quaternary volcanic deposits, and discontinuous neotectonic features.

RECURRENCE INTERVAL/INTERVALO DE RECURRENCIA: Unknown

SLIP RATE/TASA DE MOVIMIENTO: Unknown, probably $<0.2 \mathrm{~mm} / \mathrm{yr}$

TIME OF MOST RECENT MOVEMENT/EDAD DEL ULTIMO MOVIMIENTO: Quaternary <1.6 Ma.

Comments/Comentarios: Probably early Pleistocene based on the offset volcanic deposits.

REFERENCES/REFERENCIAS: None

\section{CO-44, GUAITARA FAULT}

FAULT NUMBER/NUMERO DE LA FALLA: CO-44

FAULT NAME/NOMBRE DE LA FALLA: Guaitara

SYNOPSIS AND GEOLOGIC SETTING/SINOPSIS Y AMBIENTE GEOLOGICO: The Guaitara fault, located to the south of the city of Pasto, offsets the Neogene volcanic cover of southwestern Colombia. The fault may be part of the Romeral fault system [CO-15]. The Guaitara fault probably extends farther south into the Republic of Ecuador.

COMPILER, AFFILIATION, \& DATE OF COMPILATION/COMPILADOR, AFILIACION Y FECHA DE COMPILACION: Gabriel Paris, INGEOMINAS, Bogotá; November 1993. Reviewed January 1997 at CRQ and UNIQUINDIO, Armenia. Revised by Gabriel Paris, Estudios Geológico Mineros, Cali; June 1998.

TYPE OF STUDIES/TIPOS DE ESTUDIOS: Interpretation of aerial photographs, field studies in geomorphology, and regional geologic mapping.

GEOMETRY OF THE FAULT/GEOMETRIA DE LA FALLA:

LENGTH/LONGITUD: $36.1 \mathrm{~km}$ (36.1 km cumulative)

AVERAGE STRIKE/RUMBO PROMEDIO: $44.1^{\circ} \pm 4^{\circ}\left(\mathrm{N} 44.1^{\circ} \mathrm{E} \pm 4^{\circ}\right)$

AVERAGE DIP/INCLINACION PROMEDIO: Probably high to the east

SENSE OF MOVEMENT/SENTIDO DE MOVIMIENTO: Dextral (right-lateral)

Comments/Comentarios: Vertical component is west-side up. Dextral according to the common behavior of other near by Quaternary faults; compatible with the current WSW-ENE compressional stress field.

GEOMORPHIC EXPRESSION/EXPRESION GEOMORFOLOGICA: Well developed deep V-shaped valleys, linear topographic features, fault-controlled drainage, deflected streams, and elongated hills.

RECURRENCE INTERVAL/INTERVALO DE RECURRENCIA: Unknown

SLIP RATE/TASA DE MOVIMIENTO: Unknown, probably 0.2-1 mm/yr

TIME OF MOST RECENT MOVEMENT/EDAD DEL ULTIMO MOVIMIENTO: Quaternary <1.6 Ma.

REFERENCES/REFERENCIAS

Paris, G., Marin, P., Romero, J., y Wagner, J.J., 1989, "Actividad Neotectónica en el Suroccidente Colombiano": Memorias $5^{\circ}$ Congreso Colombiano de Geología, Bucaramanga, Marzo 14-17, Soc. Col. de Geol., p. 193-213 (Bogotá).

Paris, G., 1993, Investigación Neotectónica en los Sistemas de Falla de Romeral y Cali-Patía, Departamento del Valle, Colombia: VI Seminario Internacional sobre Ingeniería Sísmica, Universidad de los Andes, Santafé de Bogotá, p. 1-29.

Paris, G., y Romero, J., 1994, Fallas Activas en Colombia: INGEOMINAS, Boletin Geológico, v. 34, no. 2-3, p. 3-26 (Santafé de Bogotá).

\section{CO-45, LA PLATA (CHUSMA) FAULT}

FAULT NUMBER/NUMERO DE LA FALLA: CO- 45

FAULT NAME/NOMBRE DE LA FALLA: La Plata (Chusma) (fault)

SYNOPSIS AND GEOLOGIC SETTING/SINOPSIS Y AMBIENTE GEOLOGICO: La Plata (or Chusma) fault extends across the eastern slope of the Cordillera Central de Colombia, southeast of the city of Neiva in 
southwestern Colombia. The fault displaces Triassic, Jurassic and Cretaceous sedimentary rocks, as well as Tertiary volcanic rocks.

COMPILER, AFFILIATION, \& DATE OF COMPILATION/COMPILADOR, AFILIACION Y FECHA DE COMPILACION: Gabriel Paris, INGEOMINAS, Bogotá; November 1993. Reviewed January 1997 at CRQ and UNIQUINDIO, Armenia. Revised by Gabriel Paris, Estudios Geológico Mineros, Cali; June 1998.

TYPE OF STUDIES/TIPOS DE ESTUDIOS: Interpretation of aerial photographs, general reconnaissance field studies.

GEOMETRY OF THE FAULT/GEOMETRIA DE LA FALLA:

LENGTH/LONGITUD: $113.2 \mathrm{~km}$ (115.1 km cumulative)

AVERAGE STRIKE/RUMBO PROMEDIO: $39.0^{\circ} \pm 12^{\circ}\left(\mathrm{N} 39.0^{\circ} \mathrm{E} \pm 12^{\circ}\right)$

AVERAGE DIP/INCLINACION PROMEDIO: $40^{\circ}-60^{\circ} \mathrm{W}$

SENSE OF MOVEMENT/SENTIDO DE MOVIMIENTO: Dextral (right-lateral) reverse

Comments/Comentarios: Vertical compoent is west-side up.

GEOMORPHIC EXPRESSION/EXPRESION GEOMORFOLOGICA: Coalescent Quaternary alluvial-fan

deposits are offset by the Plata fault. The trace is characterized by old retreated and declined scarps, en echelon semiparallel (associated) faults that cut alluvial deposits of the Paez River and local lahars, a well developed topographic fault-line expression, and a probable pull-apart basin filled with Quaternary alluvialfans and alluvium near the town of La Plata.

RECURRENCE INTERVAL/INTERVALO DE RECURRENCIA: Unknown

SLIP RATE/TASA DE MOVIMIENTO: Unknown, probably 0.2-1 mm/yr

Comments/Comentarios: Slip rate estimated from geomorphic expression.

TIME OF MOST RECENT MOVEMENT/EDAD DEL ULTIMO MOVIMIENTO: Quaternary, <1.6 Ma.

Comments/Comentarios: Known to be late Quatenary (<130 k.y.).

REFERENCES/REFERENCIAS

Diederix, H., and Gomez, H., 1991, Mapa Geologico Sur del Departamento del Huila; Esc. 1:100.000; Publ. Esp. Revista CIAF, V. 13-2; Instituto Geografico Agustin Codazzi, Bogotá, Colombia.

Paris, G., Marin, P., Romero, J., y Wagner, J, J., 1989, "Actividad Neotectónica en el Suroccidente Colombiano": Memorias $5^{\circ}$ Congreso Colombiano de Geología, Bucaramanga, Marzo 14-17, Soc. Col. de Geol., p. 193-213 (Bogotá).

Paris, G., y Romero, J., 1994, Fallas Activas en Colombia: INGEOMINAS, Boletin Geológico, v. 34, no. 2-3, p. 3-26 (Santafé de Bogotá).

\section{CO-46, IRLANDA FAULT}

FAULT NUMBER/NUMERO DE LA FALLA: CO-46

FAULT NAME/NOMBRE DE LA FALLA: Irlanda

SYNOPSIS AND GEOLOGIC SETTING/SINOPSIS Y AMBIENTE GEOLOGICO: The Irlanda fault extends through the axis of the Cordillera Central, east of the city of Popayan. It cuts igneous and metamorphic rocks that are capped with Quaternary volcanic ash and lapilli. The Irlanda fault consists of two en echelon strands, which are not shown separately in the map because of the limitations of the scale used.

COMPILER, AFFILIATION, \& DATE OF COMPILATION/COMPILADOR, AFILIACION Y FECHA DE COMPILACION: Gabriel Paris, Estudios Geológico Mineros, Cali; June 1998.

TYPE OF STUDIES/TIPOS DE ESTUDIOS: Reconnaissance (preliminary) morphotectonic field studies, geophysical and seismological surveys, terrain stability assessment, and detailed geotechnical studies.

GEOMETRY OF THE FAULT/GEOMETRIA DE LA FALLA:

LENGTH/LONGITUD: $54.6 \mathrm{~km}$ (54.7 km cumulative)

AVERAGE STRIKE/RUMBO PROMEDIO: $23.9^{\circ} \pm 4^{\circ}\left(\mathrm{N} 23.9^{\circ} \mathrm{E} \pm 4^{\circ}\right)$

AVERAGE DIP/INCLINACION PROMEDIO: Vertical

SENSE OF MOVEMENT/SENTIDO DE MOVIMIENTO: Dextral (right-lateral)

GEOMORPHIC EXPRESSION/EXPRESION GEOMORFOLOGICA: The fault trace has medium geomorphic expression and, although somewhat obscure, there are offset spurs, degraded fault scarps, broad fault valleys, saddles, aligned drainage, and deflected streams.

RECURRENCE INTERVAL/INTERVALO DE RECURRENCIA: Unknown

SLIP RATE/TASA DE MOVIMIENTO: Unknown, probably $<0.2 \mathrm{~mm} / \mathrm{yr}$

Comments/Comentarios: There are no measurement of offset features. 
TIME OF MOST RECENT MOVEMENT/EDAD DEL ULTIMO MOVIMIENTO: Historic? (1994)

Comments/Comentarios: Fault is possibly historic based on association with the large $1984 \mathrm{Paez}$ earthquake (see below)

NAME OF EARTHQUAKE/NOMBRE DEL TERREMOTO: Paez

DATE/FECHA: 06/04/94, Time: 20:47:39.9

DEPTH/PROFUNDIDAD: $10 \mathrm{~km}$

MAGNITUDE OR INTENSITY/MAGNITUD O INTENSIDAD: M 6.4

Comments/Comentarios: Active fault length is about $40 \mathrm{~km}$ long based on distribution from earthquake aftershocks. No surface rupture was observed.

REFERENCES/REFERENCIAS

Asociación Colombiana de Ingeniería Sísmica (AIS) 1996, INGEOMINAS—Uniandes, Estudio general de la amenaza sísmica en Colombia: INGEOMINAS, Bogotá, $254 \mathrm{p}$.

RED SISMOLOGICA NACIONAL DE COLOMBIA, 1994: Boletin Mensual de Sismos, v. 2, no. 6, 6 p. (Santafé de Bogotá).

Vergara, H., Paris, G., Taboada, A., Romero, y J., Castro, E., 1996, Actividad Neotectónica en las Fuentes Sismogénicas de la Región Central de Colombia: Memorias VII ( $7^{\text {th }}$ ) Congreso Colombiano de Geología, INGEOMINAS, Santafé de Bogotá, Colombia, $13 p$.

\section{CO-47, LA DINA FAULT}

FAULT NUMBER/NUMERO DE LA FALLA: CO- 47

FAULT NAME/NOMBRE DE LA FALLA: La Dina

Comments: Diederix and Gomez, 1991, have assigned the following local names to the southern extension of this fault, from north to south: Betania, Pital-Agredo and Magdalena.

SYNOPSIS AND GEOLOGIC SETTING/SINOPSIS Y AMBIENTE GEOLOGICO: La Dina fault lies east of La Plata fault [CO-48] in southwestern Colombia. The fault displaces Jurassic, Cretaceous, and Tertiary sedimentary rocks, which are common in the upper Magdalena Valley.

COMPILER, AFFILIATION, \& DATE OF COMPILATION/COMPILADOR, AFILIACION Y FECHA DE COMPILACION: Gabriel Paris, INGEOMINAS, Bogotá; November 1993. Reviewed January 1997 at CRQ and UNIQUINDIO, Armenia. Revised by Gabriel Paris, Estudios Geológico Mineros, Cali; June 1998.

TYPE OF STUDIES/TIPOS DE ESTUDIOS: Interpretation of aerial photographs and general reconnaissance studies for morphotectonics.

GEOMETRY OF THE FAULT/GEOMETRIA DE LA FALLA:

LENGTH/LONGITUD: $206.9 \mathrm{~km}$ (209.2 km cumulative)

AVERAGE STRIKE/RUMBO PROMEDIO: $32.9^{\circ} \pm 13^{\circ}\left(\mathrm{N} 32.9^{\circ} \mathrm{E} \pm 13^{\circ}\right)$

AVERAGE DIP/INCLINACION PROMEDIO: $40^{\circ}-60^{\circ} \mathrm{W}$

SENSE OF MOVEMENT/SENTIDO DE MOVIMIENTO: Reverse, dextral (right-lateral)

Comments/Comentarios: Vertical component is west-side up.

GEOMORPHIC EXPRESSION/EXPRESION GEOMORFOLOGICA: Fault marked by well-developed trace, abrupt slope changes, saddles, and small scarps.

RECURRENCE INTERVAL/INTERVALO DE RECURRENCIA: Unknown

SLIP RATE/TASA DE MOVIMIENTO: Unknown, probably 0.2-1 mm/yr

Comments/Comentarios: Low slip rate estimate based on geomorphic expression.

TIME OF MOST RECENT MOVEMENT/EDAD DEL ULTIMO MOVIMIENTO: Quaternary, <1.6 Ma.

REFERENCES/REFERENCIAS

Diederix,H. and Gomez,H., 1991, Mapa Geologico Sur del Departamento del Huila; Esc. 1:100.000; Publ. Esp. Revista CIAF Vol. 13-2; Instituto Geografico Agustin Codazzi, Bogotá, Colombia.

Paris, G., Marin, P., Romero, J., y Wagner, J.J., 1989, "Actividad Neotectónica en el Suroccidente Colombiano": Memorias $5^{\circ}$ Congreso Colombiano de Geología, Bucaramanga, Marzo 14-17, Soc. Col. de Geol., p. 193-213 (Bogotá). 


\section{CO-48, NAZCA SUBDUCTION ZONE}

FAULT NUMBER/NUMERO DE LA FALLA: CO- 48

FAULT NAME/NOMBRE DE LA FALLA: Nazca subduction zone

SYNOPSIS AND GEOLOGIC SETTING/SINOPSIS Y AMBIENTE GEOLOGICO: The Nazca subduction zone (and its trench) is located offshore, about $100 \mathrm{~km}$ west of Colombia's Pacific coast, but it extends to the north and south of the map area (see plate). The geometry of the roughly north-south-trending trench is fairly well defined by a cluster of earthquake hypocenters that are particulary dense between latitude $5^{\circ} \mathrm{N}$ and the Panamá-Colombia border. The northern limit is located about latitude $7^{\circ} \mathrm{N}$ along an imaginary eastwest line through Darien and Nido de Bucaramanga (Page, 1986). Normal and thrust faults occur along perpendicular nodal planes along the trench (Pennington, 1981). Seismicity associated with the Benioff zone (since 1906) has been used to estimated rates of the seismicity of the trench. The subduction zone (interface) is divided into three (informal) sections offshore of Colombia on the basis of dip and direction of plate convergence. However, these sections are described together in the following discussion.

COMPILER, AFFILIATION, \& DATE OF COMPILATION/COMPILADOR, AFILIACION Y FECHA DE COMPILACION: Gabriel Paris, Departamento de Geografía, Universidad del Valle, Cali; January 2000.

TYPE OF STUDIES/TIPOS DE ESTUDIOS: All studies are offshore, including seismic-refraction surveys

(Aldrich, 1973) CASA (Central and South America Global Positioning System; Kellogg and others, 1989), gravity studies (Case and others, 1974), general seismicity from RSN (Red Sismica Nacional de

INGEOMINAS), and bathymetric and magnetic charting (Lonsdale and Klitgord, 1978; Pennington 1981).

GEOMETRY OF THE SECTION/GEOMETRIA DE LA SECCION:

LENGTH/LONGITUD: $605.6 \mathrm{~km}$ (670.2 km cumulative)

Comments/Comentarios: Subduction zone continues well south of Colombia, along the coast of Peru and Chile. Length offshore of Colombia is only a small portion of total length.

AVERAGE STRIKE/RUMBO PROMEDIO: $12.4^{\circ} \pm 31^{\circ}\left(\mathrm{N} 12.4^{\circ} \mathrm{E} \pm 31^{\circ}\right)$

AVERAGE DIP/INCLINACION PROMEDIO: Variable, low angle to the east

Comments/Comentarios: According to Pennington (1981), the dip of Benioff zone (and subduction

interface) varies along strike from $20^{\circ}-25^{\circ} \mathrm{E}$ in the northern part (Bucaramanga section), to $30^{\circ}-33^{\circ} \mathrm{E}$ in the central part (Cauca section), and about $35^{\circ} \mathrm{E}$ in the southern section near Ecuador.

SENSE OF MOVEMENT/SENTIDO DE MOVIMIENTO: Underthrusting to the east (landward)

Comments/Comentarios: This is the main subduction interface. The northern section has a movement vector of $109^{\circ}$ (ca. E), the central or Cauca section has a movement vector of $120^{\circ}$ (ESE), and the southern section near Ecuador has a movement vector to the NNE (Mann and Burke, 1993). The average direction is indicated with the vector in the inset map as approximately ENE.

GEOMORPHIC EXPRESSION/EXPRESION GEOMORFOLOGICA: The surficial expression of the trench is well expresed in the bathimetry between Ecuador and Panamá. Location shown of map is approximate owning to poor control.

RECURRENCE INTERVAL/INTERVALO DE RECURRENCIA: Unknown

Comments/Comentarios: Although unknown, the extremely high plate convergence rate suggest that large interface earthquakes (with several meters of slip) must occur over time intervals of hundreds of years (see comments below)

SLIP RATE/TASA DE MOVIMIENTO: About $70 \mathrm{~mm} / \mathrm{yr}$

Comments/Comentarios: Calculated by Kellogg and Vega (1995) based on GPS measurements.

TIME OF MOST RECENT MOVEMENT/EDAD DEL ULTIMO MOVIMIENTO: Historic (1906, 1942, 1958, 1979)

Comments/Comentarios: Four shallow but large Ms $>7$ subduction-related earthquakes have occurred in the past 100 years (20th century). In 1906, an earthquake ruptured more than $400 \mathrm{~km}$ of the trench from Ecuador to the north. Three smaller events in 1942, 1958, and 1979 ruptured the same length as in 1906. In November 1991, a smaller earthquake (M6.6) nucleated $100 \mathrm{~km}$ to the north of the inferred location of the 1906 event (Freymueller and others, 1993). Most of the seismicity occurs at depths of $<300 \mathrm{~km}$ beneath western Colombia. Buried trees along the Bahia Solano fault [CO-10] record coastal subsidence from large earthquakes of the subducting Nazca plate; this relationship is similar to those found landward from the Cascadia subduction zone in Oregon, Washington, and northernmost California (Willam Page, written comunication to Michael Machette, July 9, 1999). 


\section{REFERENCES/REFERENCIAS}

Aldrich, L.T., 1973, Proyecto Nariño, an onshore-offshore geophysical study of southern Colombia and Ecuador: Editorial Guadalupe Ltda., Bogotá, Colombia, $313 p$.

Case, J.E., 1974, Oceanic crust forms basement of eastern Panamá: Geological Society of America Bulletin, v. 85, p. $645-652$.

Freymueller, J.T., Kellogg, J.N., and Vega, V., 1993, Plate motions in North Andean Region: Journal of Geophysical Research, v. 98, no. B12, p. 21853-21863.

Kellogg, J., and Vega, V., 1995, Tectonic development of Panama, Costa Rica and Colombian Andes: Constrains from Global Positioning System geodetic studies and gravity: Geol. Soc. Am. Spec. Paper 295, p. 75-90.

Kellogg, J.N., Ogujiofor, I.J., and Kansakar, D.R., 1985, Cenozoic tectonics of the Panamá and North Andes blocks: Memiors Sixth Latin Geological Congress, Bogotá, Colombia, v. 1, p. 40-59.

Londsdale, P., and Kligord, K.D., 1978, Structure and tectonic history of the eastern Panamá basin: Geological Society of America Bulletin, v. 80, p. 1639-1684.

Page, W.D., 1986, Seismic geology and seismicity of Northwestern Colombia: San Francisco, California: WoodwardClyde Consultants Report for ISA and Integral Ltda., Medellín, 200 p.

Pennington, W.D., 1981, Subduction of the eastern Panama basin and the seismotectonics of northwestern South America: Journal of Geophysical Research, v. 86, p. 10753-10770.

\section{CO-49 SOUTH CARIBBEAN DEFORMED BELT (COLOMBIA FAULT)}

FAULT NUMBER/NUMERO DE LA FALLA: CO- 49

FAULT NAME/NOMBRE DE LA FALLA: South Caribbean deformed belt (Colombia fault)

SYNOPSIS AND GEOLOGIC SETTING/SINOPSIS Y AMBIENTE GEOLOGICO: The South Caribbean deformed belt (Colombia fault of Page, 1986) is a south- to southeast-dipping thrust-fault complex associated with an accretionary prism that bounds the offshore northern margin of Colombia and Venezuela. It extends from El Golfo de Uraba in Colombia (on the west) to near El Golfo de Cariaco in northeastern Venezuela (on the east). According to Page (1986), the southwestern end of the deformed belt probably joins the Mutatá fault [CO-07]. The deformed belt bounds the continental shelf and abyssal plain and includes the San Jacinto and Sinú fold belts of late Cenozoic age (Page, 1986). The southern overthrusted block is comprised of turbidite, carbonate, and fluvial and lacustrine sediments (Duque-Caro, 1979). The South Caribbean deformed belt could be the northern limit of modern oblique convergence between the Caribbean and South American Plates, or in the case of Colombia, the North Andes Block.

COMPILER, AFFILIATION, \& DATE OF COMPILATION/COMPILADOR, AFILIACION Y FECHA DE COMPILACION: Gabriel Paris, Departamento de Geografía, Universidad del Valle, Cali; January 2000.

TYPE OF STUDIES/TIPOS DE ESTUDIOS: Offshore: CASA (Central and South America Global Positioning System; Kellogg and others, 1989), and bathimetric sonar studies (Pennington, 1981). Onland: seismicreflexion surveys and regionl geology (Duque-Caro 1979; Page, 1986).

GEOMETRY OF THE FAULT/GEOMETRIA DE LA FALLA:

LENGTH/LONGITUD: $676.7 \mathrm{~km}$ (as shown on plate, total length is greater)

Comments/Comentarios: Fault continues well east of Colombia into offshore Venezuela (see Audemard and others, 2000). Length is only a fraction of total.

AVERAGE STRIKE/RUMBO PROMEDIO: $26.4^{\circ} \pm 27^{\circ}\left(\mathrm{N} 26.4^{\circ} \mathrm{E} \pm 27^{\circ}\right)$

Comments/Comentarios: Strike varies from N25 $-45^{\circ} \mathrm{E}$ offshore of northern Colombia. It changes to E-W east of map area, north of Venezuela (Audemard and others, 2000).

AVERAGE DIP/INCLINACION PROMEDIO: Low, variable to the southeast and south

SENSE OF MOVEMENT/SENTIDO DE MOVIMIENTO: Thrust

Comments/Comentarios: Thrusting is oblique right-lateral (dextral) resulting in northwest-southeast convergence.

GEOMORPHIC EXPRESSION/EXPRESION GEOMORFOLOGICA: Well expresed in the bathimetry. Folded Cenozoic sediments. Abrupt bathimetric slope change between continental shelf and abyssal plains (Freymueller and others, 1993).

RECURRENCE INTERVAL/INTERVALO DE RECURRENCIA: Unknown

Comments/Comentarios: Although unknown, the slip rate suggests that thrusting earthquakes (with meters of slip) must occur over time intervals of hundreds to thousands of years (see comments below). 
SLIP RATE/TASA DE MOVIMIENTO: $10 \mathrm{~mm} / \mathrm{yr}$

Comments/Comentarios: Probably $10 \mathrm{~mm} / \mathrm{yr}$ in a southeastward direction for the Caribbean Plate (underthrusting block) as calculated by Kellogg and Vega (1995) based on GPS measurements.

TIME OF MOST RECENT MOVEMENT/EDAD DEL ULTIMO MOVIMIENTO: Quaternary, <1.6 Ma Comments/Comentarios: According to Page (1986) the fault is known to cut Quaternary sediments. The most recent event is certainly younger (i.e., latest Quaternary or Holocene), although no definitive data exist to support this inference.

\section{REFERENCES/REFERENCIAS}

Audemard, F.A., Machette, M.N., Dart, R.L., and Haller, K.M., 2000, Map and Database of Quaternary Faults in Venezuela and its Offshore Regions: U.S. Geological Survey Open-File Report 00-018, 76 p., 1 plate $(1: 2,000,000$ scale).

Duque-Caro, H., 1979, Major structural elements of northern Colombia: Mem. Am. Assoc. Pet. Geol., v. 29, p. 329351.

Freymueller, J.T., Kellogg, J.N., and Vega, V., 1993, Plate motions in North Andean Region: Journal of Geophysical Research, v. 98, no. B12, p. 21853-21863.

Kellogg, J., and Vega, V., 1995, Tectonic development of Panama, Costa Rica and Colombian Andes: Constrains from Global Positioning System geodetic studies and gravity: Geol. Soc. Am. Spec. Paper 295, p. 75-90.

Kellogg, J.N., I.J. Ogujiofor, and d R. Kansakar 1985, Cenozoic tectonics of the Panamá and North Andes blocks: Mem. Sixth Lat. Geol.Congr., Bogotá, Colombia, 1, 40-59.

Mann, P. and K. Burke, 1984, Neotectonics of the Caribbean, Rev. Geophys., 22, 309-362

Page, W.D., 1986, Seismic geology and seismicity of Northwestern Colombia: San Francisco, California, WoodwardClyde Consultants Report for ISA and Integral Ltda., Medellín, 200 p.

Pennington, W. D., 1981, Subduction of the eastern Panama basin and the seismotectonics of northwestern South America: J. Geophys. Res., v. 86, p. 10753-1077 